$$
\text { Universidade de São Paulo }
$$

Faculdade de Filosofia, Letras e Ciências Humanas

\title{
O papel do "dinheiro primitivo" na economia Inca
}

\author{
Cristiana Bertazoni Martins \\ Dissertação de Mestrado em Arqueologia
}

Orientadora: Prof. Dra. Maria Beatriz Borba Florenzano

São Paulo

2001 
Aos meus pais. 


\section{RESUMO}

Essa pesquisa teve como objetivo identificar e catalogar sistematicamente os objetos que serviram como "dinheiro primitivo" na área andina durante o período conhecido como Horizonte Tardio, que vai de 1.476 a 1.534 d.C. Após este primeiro passo, tentamos precisar em quais esferas sociais estes objetos circulavam e que papel desempenhavam em cada uma delas, definindo, assim, o seu funcionamento em um sistema de valor determinado e específico.

O tema da pesquisa se justifica basicamente por dois motivos: (a) a forma insatisfatória, e muitas vezes superficial, com que os trabalhos a respeito da economia incaica tratam a questão do dinheiro; (b) o costume - ao nosso ver equivocado - de entender o "dinheiro primitivo" por meio de conceitos alheios à realidade do antigo Peru.

Para a realização dessa pesquisa foram utilizadas como fontes principais as crônicas espanholas escritas durante os séculos XVI e XVII. Sempre com o cuidado de não cair em anacronismos, fato comum quando se trata de pesquisas a respeito da economia nas sociedades consideradas arcaicas.

Esperamos com este trabalho poder contribuir para uma compreensão mais ampla do "dinheiro primitivo" e da noção de valor entre os Incas.

\section{ABSTRACT}

The scope of this research is to systematically classify and identify the objects that served as "primitive money" in the Andean region during the period know as the Late Horizon, which covers the years 1476 through 1534 A.D. We tried to indicate how these objects circulated within the various social spheres and the role they played in each one of them, in order to determine their function in a system that had definite and specific values. 
The reason to decide on this theme was basically two: (a) the inadequate and often superficial way which money issue is dealt with in the existing works on Inka economy; (b) the general understanding of "primitive money" by means of concepts which are not appropriate to the reality of ancient Peru.

This research was based on chronicles written by Spaniards during the XVI and XVII centuries. Throughout this work, we were careful not to fall into anachronism, since that usually happens in researches on economy about the so called archaic societies.

We hope that this work may be a contribution to a better understanding of "primitive money " and notion of value in the Inka society. 


\section{ÍNDICE}

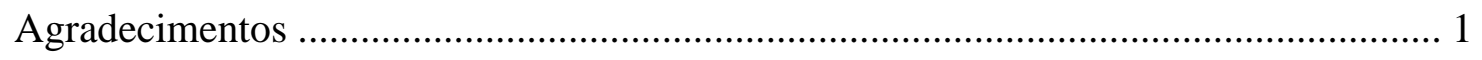

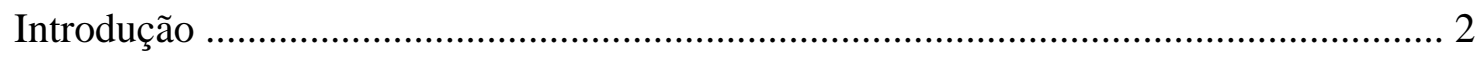

Parte I

Capítulo 1. Aspectos Econômicos do Império Inca ………............................................. 6

1.1. O sistema de reciprocidade na área andina ........................................ 10

1.2. O sistema redistributivo .............................................................. 12

1.3. O sistema de complementaridade ecológica ......................................... 15

1.4. As trocas e o mercado .......................................................................... 16

1.5. Os objetos que desempenhavam o papel de "dinheiro primitivo" ........... 19

1.6. As conchas marinhas de tipo Spondylus (mullu e chaquira) ................... 19

1.7. A pimenta de tipo aji ............................................................................. 25

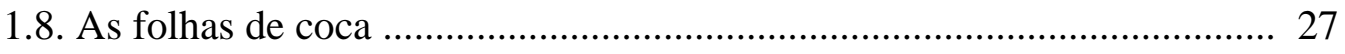

1.9. As hachitas, axe-monies ou naipes .................................................... 29

Capítilo 2. Concepções Teóricas Acerca do "dinheiro primitivo" ................................. 33

2.1. Karl Polanyi e a economia embedded ..................................................... 35

2.2. Marcel Mauss e a teoria da reciprocidade .............................................. 40

2.3. Categorias weberianas para análise das economias antigas ..................... 44

2.4. Karl Marx e o dinheiro universal ........................................................ 52

Capítulo 3. Os Cronistas e seu Tempo …............................................................ 57

3.1. A etno-história como uma ferramenta de estudo do Império Inca ........... 63

3.2. Os cronistas do Peru nos séculos XVI e XVII .......................................... 68

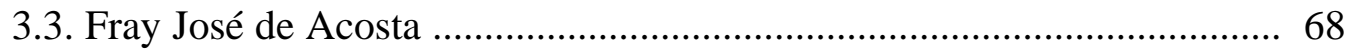

3.4. Francisco de Ávila ......................................................................... 70

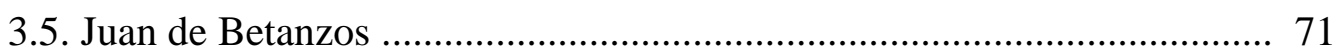

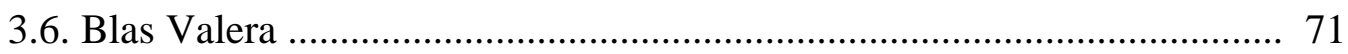

3.7. Garci Diez de San Miguel .............................................................. 71 


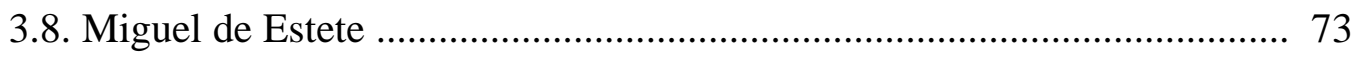

3.9. Felipe Guaman Poma de Ayala …………………………………………... 73

3.10. Juan Polo de Ondegado …………………………………………...... 75

3.11. Cristóbal Vaca de Castro ..................................................................... 76

Capítulo 4. Análise do Catálogo: O papel do "dinheiro primitivo" na Economia Inca .. 77

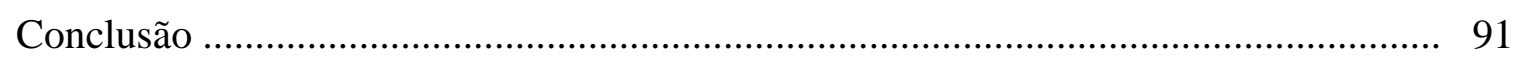

Parte II

1. Metodologia para execução do Catálogo ............................................................. 94

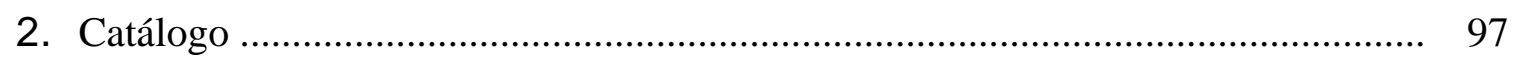

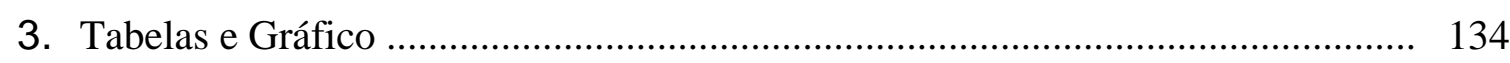

\section{Parte III}

Fontes etno-históricas utilizadas na pesquisa ......................................................... 139

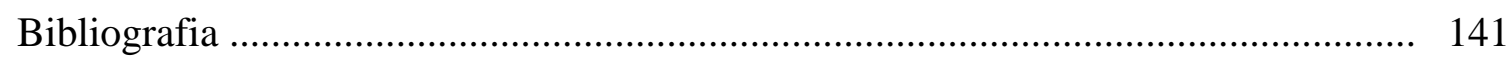




\section{AGRADECIMENTOS}

Gostaria de agradecer ao $\mathrm{CNPq}$, que desde a iniciação científica até o mestrado ofereceu-me importante incentivo por meio de bolsas de estudo.

Agradeço especialmente à minha orientadora - Profa. Dra. Maria Beatriz Borba Florenzano - que me acompanha desde os primeiros passos com a iniciação científica. Sempre prestativa, atenciosa e amiga, seu papel não se limitou ao de orientadora, mas estendeu-se ao de grande incentivadora de pesquisas sobre as civilizações pré-colombianas.

Esta pesquisa só se tornou possível graças a todos aqueles que sempre me incentivaram e apoiaram desde o seu início até a sua conclusão. Portanto gostaria de deixar registrada minha gratidão às seguintes pessoas:

Aos meus pais pelo incentivo e grande carinho que têm por mim. Aos meus irmãos Marcel e Márcia - e minhas sobrinhas Juliana e Mariana.

A todos aqueles do Museo Nacional de Arqueologia e Antropologia de Lima (Peru) e aos alunos da Universidad Nacional Mayor de San Marcos de Lima, Peru. Agradeço especialmente à Zaida Lanning do Instituto Francés de Estudios Andinos (IFEA) de Lima (Peru), cuja ajuda foi fundamental para que esta pesquisa se tornasse possível.

A todos os meus amigos do Museu de Arqueologia e Etnologia da Universidade de São Paulo (Juliana, Denise, Leila, Elaine, Ivana e Patrícia), pelo entusiasmo e amizade.

Aos colegas do Centro de Estudos Luís Martins e da Biblioteca Paulo Mendes de Almeida do Museu de Arte Moderna de São Paulo.

À Vera Penteado Coelho (in memoriam), que há alguns anos se dedicava com afinco à arqueologia peruana e de quem pude herdar uma pequena parte - mas importantíssima - de sua biblioteca pessoal.

Finalmente, agradeço especialmente ao Márcio, meu marido, pelo imenso carinho, constante apoio e por ter sempre acreditado neste trabalho. 


\section{INTRODUÇÃO}

"... cultures were neither moral examples nor living fossils but simply different and equally valued."

Franz Boas

A cultura pré-colombiana Inca, foi muito estudada por muitos especialistas que abordaram seus diversos aspectos: social, artístico, político, tecnológico, religioso e econômico. Entretanto, sobre um dos principais elementos do aspecto econômico - o dinheiro - observamos que há uma carência de estudos aprofundados, e quando esta questão é levantada, o "dinheiro primitivo" é sempre visto de forma descontextualizada e unilinear: ora concebendo-o como o início de uma cadeia evolutiva unívoca que parte das conchas e termina no cartão de crédito; ora simplesmente afirmando - a partir de uma definição moderna do dinheiro - a sua não existência nas sociedades antigas.

Esse tipo de visão é muito comum e freqüente, como pode ser visto no trecho abaixo escrito por Espinoza Soriano:

"A economia monetária oferece distintas fases evolutivas. Primeiro é o dinheiro natural representado por diversos objetos aceitos no mercado como unidade de medida para a troca. Logo, o dinheiro de metal (nem sempre metais nobres), e finalmente, o dinheiro cunhado. Existe um amplo ciclo de aperfeiçoamento até os tempos modernos em que se prescinde do dinheiro substituindo-o por valores expressos em papel" (1987: 133).

O que esta pesquisa intenta é demonstrar a impossibilidade de compreensão do "dinheiro primitivo" no interior da sociedade Inca, por meio de instrumentais teóricos de análise específicos da sociedade moderna. Por exemplo, para a moderna definição, dinheiro é todo objeto que desempenha igualmente as funções de meio de troca, medida de valor, meio de pagamento e entesouramento. Porém, esta é uma concepção específica de nossa sociedade 
baseada no sistema capitalista, cuja esfera econômica tem um grau de autonomia bastante significativo, o que não é o caso das sociedades arcaicas de modo geral (Polanyi, 1965; Mauss, 1950). Portanto, é preciso entender a economia no seio da sociedade Inca de forma contextualizada, respeitando sua especificidade.

Além disso, levantamos a hipótese de que o "dinheiro primitivo", representado no antigo Peru pelos objetos estudados aqui, não tinha um caráter exclusivamente econômico, ou seja, desempenhava um papel e possuía um significado muito importante também em outras esferas da sociedade, como por exemplo, na esfera religiosa (Espinoza Soriano, 1987; Lavallée, 1985).

Por meio de fontes escritas (relatórios de cronistas espanhóis do século XVI e XVII), relatórios de escavação e da própria bibliografia a respeito (Espinoza Soriano, 1987; Lavallée, 1985; Goldstein, 2000; Pillsburg, 1996), sabemos que entre os Incas havia determinados objetos que se distinguiam dos demais, seja funcionando, por exemplo, como objeto de prestígio, medida de valor e/ou de meio de troca. Entre eles, os mais importantes citados na bibliografia são as conchas marinhas de tipo Spondylus prínceps e Strombus galeatus, pimenta do tipo ají, folhas de coca, hachas ou hachitas de cobre, plumas, ouro e prata. No entanto, a literatura a respeito é polêmica, pois há autores que atribuem também ao milho e aos tecidos um valor tão especial quanto o dos objetos citados acima (Murra, 1975).

No caso específico dos tecidos, não há dúvidas de que sua importância social e econômica no império Inca poderia acrescentar dados muito valiosos a esta pesquisa (ver Murra, 1958). Porém, infelizmente, não foi possível o acesso às crônicas que seriam necessárias (Bernabe Cobo, Cieza de Leon, Inigo Ortiz e Múrua) para o estudo satisfatório em relação a esse artigo em especial. Dessa forma, optamos por não tratar na presente pesquisa, a respeito dos tecidos visto que nas fontes às quais tivemos acesso esse item aparece de maneira insignificante e inexpressiva. 
Para o desenvolvimento e execução deste trabalho foram realizadas leituras sistemáticas e cuidadosas das crônicas escritas por espanhóis durante os séculos XVI e XVII, textos de onde foram extraídos todas as passagens consideradas relevantes através de critérios estabelecidos e definidos previamente.

Infelizmente, esta pesquisa tem um caráter incompleto já que não foi possível o acesso à determinadas crônicas importantes para a melhor compreensão acerca do fenômeno do "dinheiro primitivo" no antigo Peru. Isto ocorreu devido à dificuldade em encontrar nas bibliotecas e livrarias brasileiras, e mesmo no exterior, esse tipo de literatura. Se por um lado, o acesso parcial às fontes principais da pesquisa impediu um número maior e mais qualitativo de informações, por outro lado, a leitura e reflexão realizadas a partir das fontes às quais tivemos acesso, permitiu um exercício frutífero e interessante acerca do "dinheiro primitivo" na economia Inca.

No primeiro capítulo foi realizada uma caracterização da economia no Império Inca e de suas principais instituições: a reciprocidade, o sistema redistributivo, a complementaridade ecológica e as trocas. Além disso, foi feito um histórico dos objetos estudados, descrevendo seus principais traços e características.

No segundo capítulo foram tratadas as questões teóricas e conceituais a respeito do "dinheiro primitivo" por meio da leitura dos autores considerados de fundamental importância para a pesquisa e também para a reflexão, de modo geral, do papel da economia nas sociedades antigas. Neste momento, foram estudados com maior cuidado os textos de Karl Polanyi, Marcel Mauss, Max Weber e Karl Marx.

Por se tratar de uma pesquisa majoritariamente baseada no estudo de fontes escritas nos séculos XVI e XVII, não poderíamos deixar de abordar algumas questões relativas às vantagens e desvantagens da etno-história, seus problemas e limites. Para tanto, no capítulo terceiro, foram feitas algumas considerações importantes sobre o estudo do Império Inca por 
meio das crônicas espanholas. Além disso, foi feito um breve histórico dos cronistas espanhóis cujos textos foram utilizados para realização desta pesquisa.

No capítulo quarto, foi realizada a interpretação dos dados e informações procedentes do catálogo e, eventualmente, de relatórios de escavação provenientes de pesquisas arqueológicas na área andina.

Finalmente, anexamos o catálogo e suas respectivas tabelas estatísticas para que o leitor possa analisar com detalhes os trechos retirado das fontes etno-históricas e a metodologia e critério empregado para seleção destes. 


\section{CAPÍTULO 1}

\section{ASPECTOS ECONÔMICOS DO IMPÉRIO INCA}

A economia Inca - essencialmente baseada na agricultura - tinha um caráter bastante heterogêneo, ou seja, não havia uma unidade de organização econômica. A complexa e variada ecologia no antigo Peru' ${ }^{1}$ influiu significativamente no desenvolvimento econômico do Império, criando formas variadas de produção e distribuição de bens, fazendo com que cada nicho ecológico tivesse características particulares, produzindo tipos diferentes de alimentos. Podemos citar, por exemplo, o caso de zonas muito áridas onde foi preciso o esforço do homem para criar complexos sistemas hidráulicos a fim de possibilitar a irrigação e, consequentemente, a agricultura (Rostworowski, 1998).

O sistema econômico do Império Inca estava baseado no controle da produção de bens de subsistência que dependiam de complexos sistemas de irrigação no litoral; e da agricultura intensiva e cíclica no altiplano. Toda a terra pertencia ao Estado, baseado nos direitos de conquista (Earle, 1990: 65).

A geografia da área andina - local onde estava assentada a cultura Inca - é caracterizada por uma grande variedade de regiões e esta heterogeneidade, longe de ser um obstáculo, significou uma variedade de recursos explorados pelos povos andinos. Para se ter uma idéia da grande diversidade ecológica da área andina, das 100 formações bio-climáticas do mundo, 35 localizam-se só no Peru (Martel, 1983-85).

A região peruana se divide geograficamente em três principais zonas: a costa, a serra e a floresta amazônica. A costa tem um clima desértico e vegetação escassa, onde existe um importante deserto chamado de Sechura, próximo à atual cidade de Tumbes, no litoral norte

\footnotetext{
${ }^{1}$ A palavra Peru é usada por arqueólogos para designar não somente a República do Peru, mas também o Altiplano Boliviano o norte do Chile e parte do Equador.
} 
do Peru. O cenário desta região seria bastante desolado se não fossem os rios que cortam transversalmente toda a costa peruana, formando vales onde se desenvolveu grande parte das culturas que floresceram na região andina e que posteriormente, foram dominadas pelos Incas. Mesmo anteriormente ao Império incaico, complexos sistemas hidráulicos e de irrigação permitiram o desenvolvimento da agricultura na costa, como por exemplo, aquedutos que levavam água às áreas mais distantes e também possibilitaram a sobrevivência dos yungas (denominação dos habitantes da região litorânea).

Outro fator fundamental para o desenvolvimento das culturas que ocupavam o litoral foi a existência em grandes quantidades de guano (excremento de aves marinhas), graças à alta piscosidade do litoral peruano. Este excremento, que serve como adubo até os dias atuais, permitiu o sucesso na agricultura costeira e propiciava boa fertilidade à terra. Dessa forma, o mar servia como uma enorme fonte de espécies marinhas para os habitantes da costa peruana (Espinoza Soriano, 1987).

$\mathrm{Na}$ serra encontramos um clima tropical-seco, vales e bacias fechadas onde a altitude chega a ser superior a 4.000 metros. A vegetação varia entre a puna, estepe ou sub-desértica e nesta zona geográfica, ocorre a plantação em terraços desde a antigüidade, justamente devido às grandes altitudes. Na floresta amazônica, há ocorrência de clima quente, subtropical e com baixa densidade demográfica.

Para alguns autores (Murra, 1975; Rostworowski, 1975; Espinoza Soriano, 1987), serra e a costa teriam sido regiões ecologicamente muito distintas entre si, e teriam sido essas peculiaridades que teriam gerado formas diferentes de sobrevivência e de organização social e econômica. Ou seja, para esses autores, enquanto a serra desenvolveu o sistema de complementaridade ecológica, utilizando diversos e diferentes meios de ter acesso aos bens e produtos (como explicaremos mais adiante), a zona da costa se caracterizou pela especialização e como conseqüência teve um comércio bastante desenvolvido. Segundo essa 
concepção, a única forma de organização econômica comum a toda a área andina, tanto na serra como na costa, foi a reciprocidade.

Para Espinoza Soriano (1987), enquanto a serra se caracterizava por uma grande influência cuzquenha/Inca, a costa tinha a especialização do trabalho, um sistema de comércio mais desenvolvido e, graças à distância de Cuzco, menor influência do sistema redistributivo em relação à serra.

No entanto, essa questão ainda gera muitas discussões e polêmicas pois, há autores que não vêem tanta diferença entre serra e costa. Para Ramírez (1996: 164), as diferenças sócioeconômicas entre serra e costa não foram tão marcantes como é freqüentemente afirmado: “em contraste com aqueles que argumentam que a estrutura sócio-econômica dos altiplanos era fundamentalmente diferente da costa, foram encontradas evidências fortes de que a base de legitimidade do curacas, a visão de recursos naturais e as regras para o seu uso, a idéia de sistema de tributo, as crenças e práticas de adoração de antepassado foram comuns à todas as comunidades andinas. Além disso, pessoas do altiplano e do litoral compartilhavam os valores de reciprocidade e redistribuição, que apoiaram a auto-suficiência de comunidades ao longo do antigo Império Inca”.

De qualquer forma, todos concordam que houve na área andina sob domínio Inca diversas formas de organização sócio-econômica: o sistema redistributivo, a reciprocidade, o controle vertical de um máximo de pisos ecológicos, além das trocas que funcionavam como uma alternativa a mais para a obtenção e acesso a produtos (Morris, 1986; Murra, 1975; Earle, 1990; LeVine, 1987). 


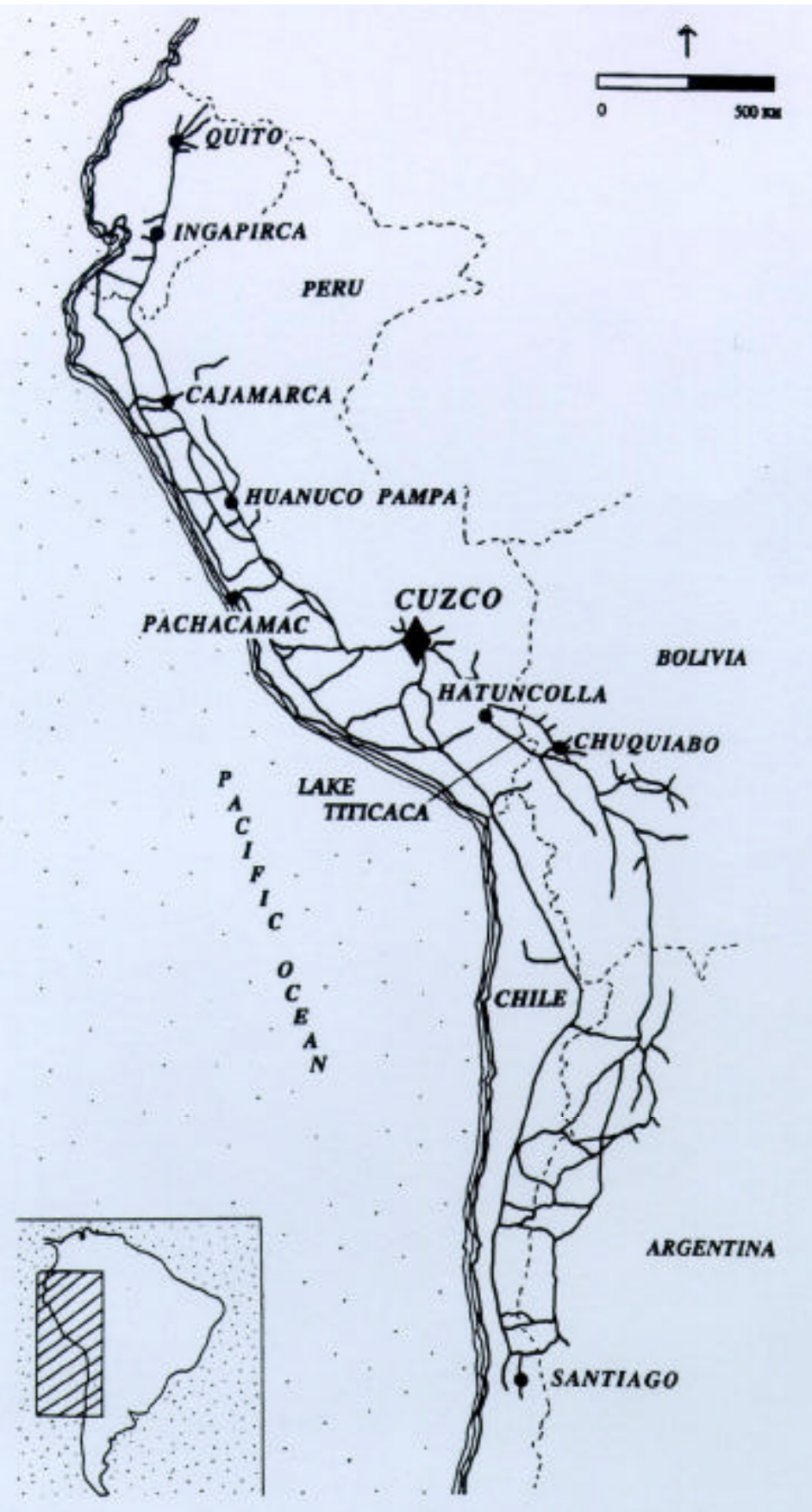

Extensão do império Inca com seus caminhos e principais sitios arqueológicos. Adaptado de Stanish (1997). 


\subsection{O sistema de reciprocidade na área andina}

A reciprocidade era uma antiga organização sócio-econômica pré-incaica que regulava a prestação de serviços em diversos níveis e servia como uma engrenagem na produção e distribuição de bens. Caracterizava-se pela prestação de serviços através de petições feitas por chefes para que seus subalternos executassem determinadas tarefas como, por exemplo, a agricultura e a construção civil. Em troca, esses subalternos recebiam produtos de que necessitavam em forma de presentes (Rostworowski, 1975).

O conceito de reciprocidade foi desenvolvido pela Antropologia e se aplica a inúmeras sociedades antigas. A reciprocidade foi uma qualidade comum a todas as formas de organização econômica andina e pode ser vista como um laço ancestral muito importante e tradicional no antigo Peru. Posteriormente, esta tradicional reciprocidade se transformou no sistema redistributivo incaico graças à maior centralização do poder central (Rostworowski, 1975; Valensi, 1974). Houve, em diferentes momentos (pré-Inca e Inca), dois níveis de reciprocidade na área andina: a reciprocidade tradicional das comunidades rurais ou ayllus ${ }^{2}$, e a reciprocidade do Estado Inca que funcionava à base de um aparato militar, administrativo e burocrático que se beneficiava das prestações de serviço de seus súditos, primeiramente arrecadando toda produção em forma de $m i t a^{3}$ e posteriormente redistribuindo o excedente (Murra, 1978). Este último corresponde ao sistema redistributivo incaico em sua mais perfeita forma.

A reciprocidade tradicional e pré-incaica era um ritual em que, primeiramente, os chefes de determinadas comunidades rurais se reuniam e presenteavam generosamente seus súditos através de festas. Após este primeiro momento, e somente após, faziam uma petição para que determinada tarefa fosse efetuada. Feita a tarefa, os chefes deveriam novamente se

\footnotetext{
${ }^{2}$ Ayllu é o nome dado às comunidades étnicas da área andina, ligadas entre si por laços de parentesco.

${ }^{3}$ Mita era o serviço rotativo e obrigatório do membro adulto do ayllu que durava de 3 meses a 1 ano.
} 
reunir e presentear generosamente seus subalternos através de uma segunda festa recheada de muitos presentes e chich $a^{4}$.

A generosidade do chefe em presentear deveria ser enfática pois, seus subalternos poderiam ou não aceitar o pedido e isto era definido pela qualidade da festa e quantidade de presentes.

O momento da petição era importantíssimo e muito tradicional, pois todas as etapas da reciprocidade eram igualmente importantes e fundamentais. Da execução de suas várias etapas, pode-se dizer, dependia parte da sobrevivência da reciprocidade andina (Ramírez, 1996).

Este nível de reciprocidade tem origens muito antigas, pré- incaicas (Rostworowski, 1975), e sobreviveu desta forma até o início da expansão Inca, quando sofreu algumas transformações no momento em que o Império se consolidou no poder mais firmemente.

Em relação à reciprocidade incaica, será necessário observarmos dois diferentes momentos referentes ao Império Inca. O primeiro momento refere-se aos primórdios da expansão imperial, quando o Estado assimilou o sistema de reciprocidade já tradicional na área andina. Os imperadores Incas quiseram praticar a reciprocidade sem as petições e requerimentos tradicionais, porém isto não foi possível porque além da ancestralidade do sistema de reciprocidade, Yupanqui - Imperador Inca da época - ainda não possuía poder e domínio absoluto sobre os chefes das comunidades rurais e de seus subalternos em geral (Rostworowski, 1975).

Em um segundo momento, quando o império Inca já estava consolidado e muito mais influente sobre os povos dominados, o Estado passou a agir mais diretamente através dos yanas. Os yanas eram pessoas retiradas de seus ayllus de origem e enviados para locais

\footnotetext{
${ }^{4}$ Chicha é uma bebida muito apreciada até os dias de hoje na área andina, feita a base de milho fermentado.
} 
distantes para cumprir tarefas e trabalhos obrigatórios, porém agora diretamente para o Estado Inca. Havia yanas de diversas categorias, podiam ser simples camponeses ou artesãos especializados. Neste momento foi de fundamental importância as relações entre o Inca e os chefes do ayllu, estes últimos que a partir de então, passaram a se chamar curacas.

Desse modo, a partir da expansão incaica e de seu conseqüente domínio sobre as etnias locais e periféricas, o sistema de reciprocidade sofreu algumas alterações transformando-se ao longo do tempo, no sistema redistributivo incaico. Os Incas, através de seu aparato militar e administrativo, passaram a controlar mais efetivamente os recursos econômicos, a produção, distribuição e consequentemente as comunidades étnicas

Um importante personagem nesse contexto, foi a do curaca que continuava atuando como um chefe do ayllu, porém agora, sob às ordens diretas do poder incaico. Como funcionário do Estado Inca, o curaca não era dono das terras locais e muito menos de seus súditos, ele era apenas um administrador e representante do Estado que deveria cuidar da produção e da arrecadação de tributos para o Estado Inca, além do bem-estar de seus subalternos. Esta última questão era de importância fundamental pois, para ser um bom curaca deveria ser generoso ao presentear seus súditos, como podemos ver em um exemplo referente a um dos curacas de Cuenca: “... curacas de Cuenca falavam da necessidade de prover chicha e comida aos seus súditos como parte de troca ritual de serviços. Sem esses incentivos os súditos poderiam não obedecer" (Ramírez, 1996: 20-21).

\subsection{O sistema redistributivo}

O controle do trabalho, baseado no sistema de redistribuição, por parte do Estado Inca foi um elemento chave para a economia Inca e foi graças a isso que o Império pode se expandir e se manter. 
O sistema redistributivo consistia essencialmente no sistema de mita em que trabalhadores contribuíam ou prestavam serviços ao Estado por meio de trabalhos temporários, nunca por meio de tributos em espécies: "...a fonte principal dos ingressos do Estado era a mita, a energia procedente dos muitos grupos étnicos que trabalhavam os campos cedidos pelo Estado. A mita incluía o pastoreio, a tecelagem de muitas variedades de prendas e a coleta de produtos em bosques e lagos" (Murra, 1983: 90).

A mita ou prestação de serviços rotativos é um conceito andino empregado para designar trabalhos organizados ciclicamente em um determinado momento. Esta forma de prestação de serviços se realizava em diversos níveis, ou seja, ocorria em nível local e estatal (Rostworowski, 1998: 259).

A demanda estatal de produtos era proporcional ao tamanho da população e também eram considerados aspectos ambientais e climáticos. O Estado Inca tinha um controle altamente centralizado sobre as etnias que conquistava e conseguia seus objetivos e desejos delegando poder econômico e político aos chefes locais que passavam a ter responsabilidades diretas sobre os mecanismos econômicos de suas comunidades (Le Vine, 1987: 39).

Tanto a idade como a habilidade poderiam determinar o tipo de trabalho a ser executado. Por exemplo, jovens solteiros geralmente cuidavam de buscar mel e plumas em regiões mais distantes e também podiam ser usados como mensageiros para o exército estatal. Já as mulheres, eram designadas, geralmente, para a tecelagem (Le Vine, 1987: 26).

Um estudo de caso baseado em documentos etno-históricos referentes à localidade de Chupachu no Vale de Huallaga, região centro-norte do Peru, demonstra que havia três grupos ou tipos de trabalhadores. O primeiro grupo, representado pela maioria da força laboral, trabalhava por períodos ou turnos estipulados e cultivava as áreas de regiões locais. Essas regiões providenciavam sua própria subsistência e quando se envolviam em projetos estritamente estatais, eram sustentados pelo Império. O segundo grupo é representado por 
trabalhadores de tempo integral e que eram sustentados pelo Estado. Finalmente, trabalhadores permanentemente removidos de seus grupos étnicos e que se dedicavam às tarefas básicas do Estado, representam o terceiro grupo. Neste caso, são incluídos os artesão especializados e as mulheres que fabricavam chicha exclusivamente para a elite imperial. Este grupo trabalhava em tempo integral e era totalmente sustentado pelo Estado (Le Vine, 1987: 20).

Havia basicamente três tipos de mercadorias que eram supridas pelo Estado por meio do sistema redistributivo: 1. artigos de subsistência e utilitários que eram transportados e armazenados em depósitos estatais; 2. artigos que satisfaziam as necessidades militares e 3. objetos de valor e prestígio que eram enviados diretamente para os depósitos do Cuzco (Le Vine, 1987: 15).

Neste estudo de caso, citado acima, observou-se que os Incas davam mais valor aos territórios produtores de coca e ají, além de regiões próximas à floresta tropical de onde procediam plumas de aves de pássaros tropicais. Em vales onde o clima permitia o cultivo desses artigos, muito apreciados em toda a área andina, era comum o Estado expulsar parte da população nativa e enviá-la para outro lugar a fim de melhor controlar esses recursos naturais. Na visita à Chupachu em 1562, o cacique principal declarou que ele enviava as plumas comuns para Huánaco Pampa e as melhores para Cuzco, indicando que o Estado supervisionava diretamente a produção desse material (Le Vine, 1987: 26; 30).

Um elemento fundamental que contribuía para a manutenção e dava estabilidade ao Império era o depósito, tambo, estatal. Os produtos agrícolas e os objetos manufaturados eram acumulados nesses depósitos estatais e eram convertidos em bens facilmente disponíveis ao Inca. Esses bens davam ao Império uma incontestável superioridade sobre os senhores locais e grande parte das forças do Estado se apoiava nessas riquezas acumuladas: "conseguir um excedente substancial na produção não servia somente para a redistribuição estatal e para 
cobrir as exigências da reciprocidade, mas também conferia ao governo Inca uma acumulação de bens rentáveis que simbolizavam seu poder" (Rostworowski, 1998: 281).

Estes depósitos, localizados em inúmeros pontos da área andina, além de funcionarem como manutenção imperial, serviam também como controle de etnias locais por meio de objetos de prestígio, uma vez que esses depósitos guardavam também grande quantidade de artigos não-utilitários (Morris, 1986: 67).

\subsection{O sistema de complementaridade ecológica ou Controle Vertical de um Máximo de Pisos Ecológicos}

A complementaridade ecológica foi mais um dos meios utilizados pelas comunidades para driblar a questão da enorme diversidade ecológica da área andina que, devido às diferenças de meio ambiente tinham formas de organização também diferentes (Murra, 1975; Earle, 1990). Segundo John Murra (1978), este tipo de organização se desenvolveu graças à combinação simultânea de três sistemas econômicos: a) acesso direto às unidades domésticas de uma comunidade, ou seja, usufruto direto dos recursos locais; b) o controle vertical de um máximo de pisos ecológicos através de "colonos" de cada grupo étnico, isto é, o envio de "colonos" que iam e voltavam para zonas diferentes para que fosse possível o uso de recursos não disponíveis no local de origem, e c) o intercâmbio de produtos.

Isto significa que as comunidades étnicas usufruíam diretamente do nicho ecológico que ocupavam porém, isto não era suficiente para suprir todas as necessidades do grupo. A outra alternativa encontrada foi o chamado controle vertical de um máximo de pisos ecológicos, um padrão andino pré-incaico, mas que sobreviveu também em época Inca. Nesse caso, cada comunidade enviava "colonos" para o controle de recursos naturais em outro território - geralmente em locais mais altos e utilizando o sistema de agricultura em terraços suprindo assim o déficit inicial de recursos daquela comunidade. Cada grupo étnico tendia a 
ocupar um território que incluía várias regiões naturais até onde fosse possível, assim cada pequena comarca ou comunidade podia diversificar ao máximo seus cultivos dentro dos limites de seu território (Martel, 1983-85). Ainda assim, como estes dois recursos de acesso à terra, não se atingia o suficiente para poder suprir as necessidades da comunidade, recorria-se também à troca de produtos com comunidades de outras localidades e de outros nichos ecológicos. Esses vários meios de obtenção de produtos não eram excludentes mas, pelo contrário, ocorriam simultaneamente dentro da complexa economia andina.

Alguns destes sistemas ainda persistem na região andina nos dias de hoje, o que não quer dizer que sua economia seja estática, mas representa a eficácia desses antigos sistemas de produção que conseguiram sobreviver mesmo com o advento de novas formas de produção e de novas tecnologias.

\subsection{As trocas e o mercado}

Em muitas ocasiões, os habitantes da área andina eram levados ou optavam pelo comércio devido à necessidade de obter produtos variados e que, por um motivo ou por outro, não eram conseguidos através das demais formas de acesso a produtos citadas acima.

Em época Inca houve basicamente dois tipos de comércio: o comércio local e o comércio de longa distância. Segundo Espinoza Soriano (1987), as trocas realizadas pelo comércio local efetuavam-se por meio do intercâmbio de produtos entre as própria famílias ou etnias mas, principalmente, nos catus, que significa mercado em quechua, a língua falada pelos nativos. A origem desses mercados é pré-incaica, porém esta é uma instituição que sobreviveu na forma tradicional dos povos pré-colombianos até depois da conquista espanhola. Os mercados tiveram grande importância e funcionavam de forma intensa, já que a população tanto serrana como costeira, participava deles. 
O mercado deve ser entendido aqui dentro do contexto econômico que lhe é próprio, ou seja, a área andina. Neste caso, mercado não significa fluxo de mercadorias e serviços baseados em mecanismos de fixação de preços. Isto é, valores estabelecidos por meio de decisões entre compradores e vendedores baseados na lei da oferta e da procura, com a mínima intervenção do Estado.

No caso do Império Inca, o mercado (no sentido de local ou praça onde pessoas de diversos locais se reuniam para efetivar trocas e intercâmbios; e não na concepção moderna de economia de mercado), funcionava de forma intensa, mas não de maneira competitiva em que os mercadores atuavam individualmente em busca do lucro por meio da diferença entre preços. Mas, pelo contrário, agiam para autoridades políticas e eram parte integrante do sistema de expansão imperial pois, trabalhavam manipulando elites locais por meio, entre outros, de objetos exóticos e de valor. Ou seja, os mercadores estavam ligados à elite ou às instituições do governo para quem eles proporcionavam serviços especiais. Os mercadores existiam por causa das vantagens que ofereciam ao Estado (Stanish, 1997: 198).

A importância dos objetos de valor e do "dinheiro primitivo" estava na habilidade do Império em constituir poder e legitimar sua dominação por meio desses objetos (Goldstein, 2000: 337).

Ainda segundo Espinoza Soriano (1987), o comércio de longa distância desenvolveuse com maior intensidade na região da costa, era representado pelo mercador ou caturuna, na língua quechua. Estes mercadores serviam como intermediários entre o produtor e o consumidor e, apesar de não estarem envolvidos diretamente na produção, eram tão úteis quanto o produtor. O mercador era o grande agente que colocava em prática o comércio entre diferentes zonas.

Este tipo de comércio era chamado de longa distância porque ele se estendia a regiões muito distantes: os mercadores iam da costa à serra usando lhamas como meio de transporte 
terrestre e com balsas iam pelo mar até as cidades mais distantes ao norte do império. O grande e principal papel desempenhado pelo comércio de longa distância através do mar, foi o de buscar nas terras mais quentes as famosas conchas cerimoniais Spondylus princeps e Strombus galeatus, consideradas como artigos de luxo e prestígio e eram - freqüentemente depositadas em enterramentos e santuários (Masucci, 1995).

Um estudo realizado por Salomon, na região norte do Equador e sul da Colômbia demonstra que além dos modelos econômicos clássicos incaicos (redistribuição, complementaridade e reciprocidade), havia áreas dentro do Império que fugiam à essa regra. Segundo o autor, na região estudada existia uma categoria de mercadores com status político chamados mindaláes, cujas especialidades incluía o uso de um tipo de special purpose money representado pela chaquira (contas de conchas e de ossos ) e pelo chagual, uma espécie de botão de ouro (Salomon, 1987: 64).

Esses mercadores tinham prestígio e autoridade para operar extra-territorialmente e constituíam uma categoria social única e incomum pois, pagavam, com mercadorias suntuárias, diferentes taxas de tributos aos seus senhores.

Tanto a chaquira como o chagual eram utilizados por nobres e pessoas comuns para comprar no mercado. No entanto, além da função de dinheiro, a chaquira também desempenhava uma função política e suntuária. Apesar de sua ampla trajetória em toda a sociedade, tendia a se concentrar nas mãos de senhores (Salomon, 1987: 66).

Este estudo de caso nos incita a questionar por que algumas vezes o Império permitia a sobrevivência de algumas instituições fora da regra geral. A questão torna-se difícil de responder se imaginarmos que a intervenção imperial ocorria de forma abrupta. Porém, a questão torna-se mais compreensível se considerarmos que o Império Inca adaptava a sua administração às diferentes regiões e etnias que dominava e que havia uma enorme heterogeneidade de relacionamentos entre o centro imperial e as áreas periféricas. Nenhum 
império - por mais maduro que seja - é monolítico e uniformemente integrado com todas as suas parte constitutivas (Stanish, 1997: 196).

\subsection{Os objetos que desempenhavam o papel de "dinheiro primitivo"}

Através da bibliografia disponível, foi possível identificarmos alguns dos principais objetos que de alguma forma incorporavam valor e participavam do sistema de trocas.

A bibliografia especializada, explora o fato de que os povos da área andina davam valor especial para determinados objetos que por vezes atuavam nas trocas e que foram, por isso, definidos genericamente como "dinheiro primitivo". No entanto, ainda não há clareza de como esses objetos realmente eram usados e se, de fato, é possível situar todos na categoria de "dinheiro primitivo". Não se sabe, por exemplo, se há entre eles objetos exclusivamente de

prestígio. É preciso então que a definição de "dinheiro primitivo" (ver capítulo 2), seja clara e concisa, e que se tome sempre o cuidado de não transpor mecanicamente a noção de valor atual para as sociedades antigas ou arcaicas.

\subsection{A conchas marinhas de tipo Spondylus (mullu ou chaquira)}

As conchas marinhas Spondylus princeps e Spondylus galeatus, também conhecidas como mullu ou chaquira em quechua, são encontradas em águas quentes e moderadamente profundas (15 à 50 metros), como o Golfo da Califórnia e entre o Panamá e o norte do Peru. O Spondylus têm sido freqüentemente encontrado em diversos sítios arqueológicos no Peru como, por exemplo, Batán Grande, em Sícan, Sipán (próximos à cidade de Lambayeque), El Oro, Manabí, Los Rios e muitos outros lugares. Além disso, aparece em vários e diferentes contextos arqueológicos, principalmente, em enterramentos de pessoas da elite e em santuários religiosos (Pillsbury, 1996: 317). 


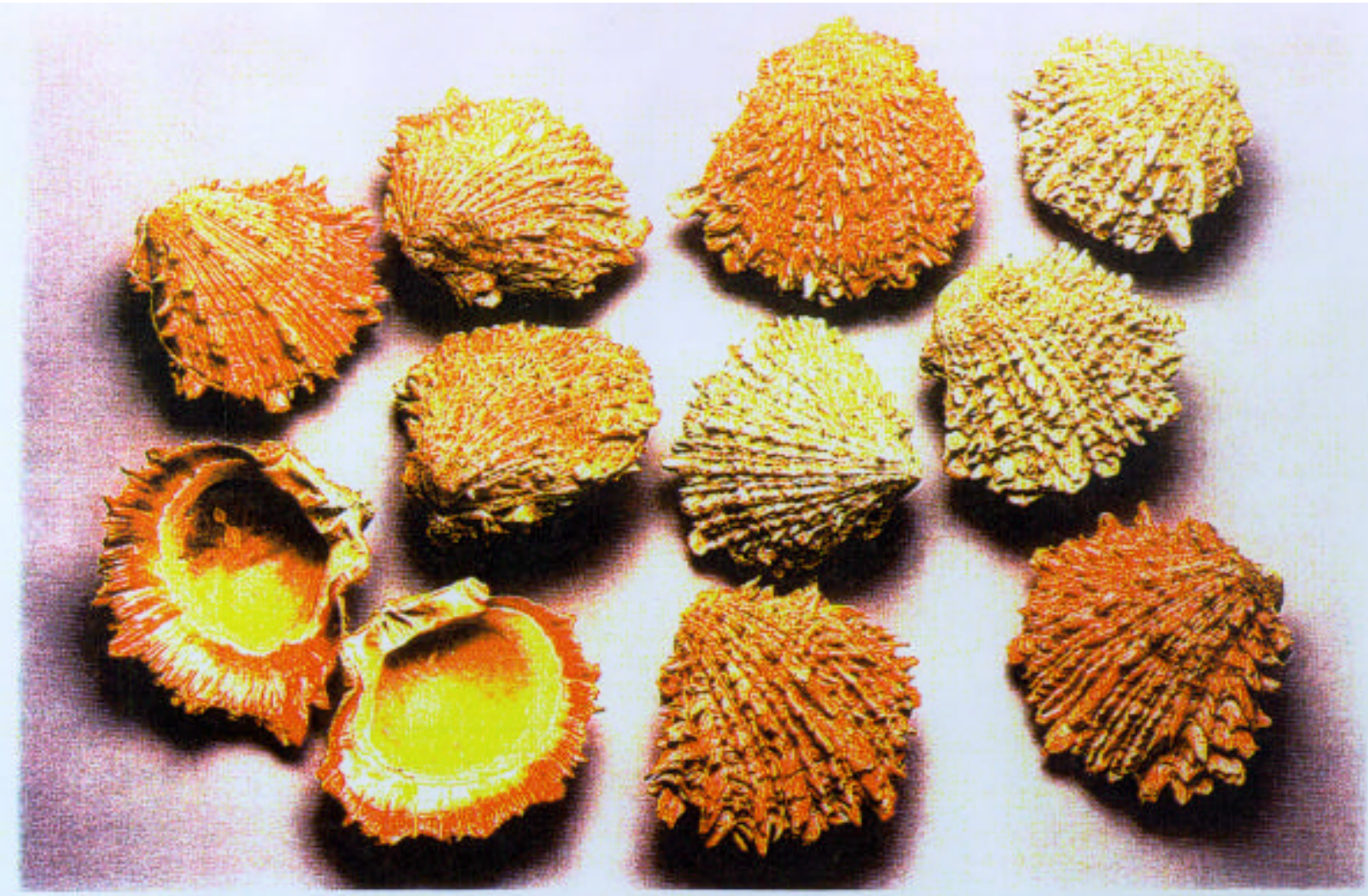

Exemplares de conchas marinhas de tipo Spondylus encontradas em Sicán, norte do Peru. Fonte: Sicán Project, TBS, 1994-1996: 147.

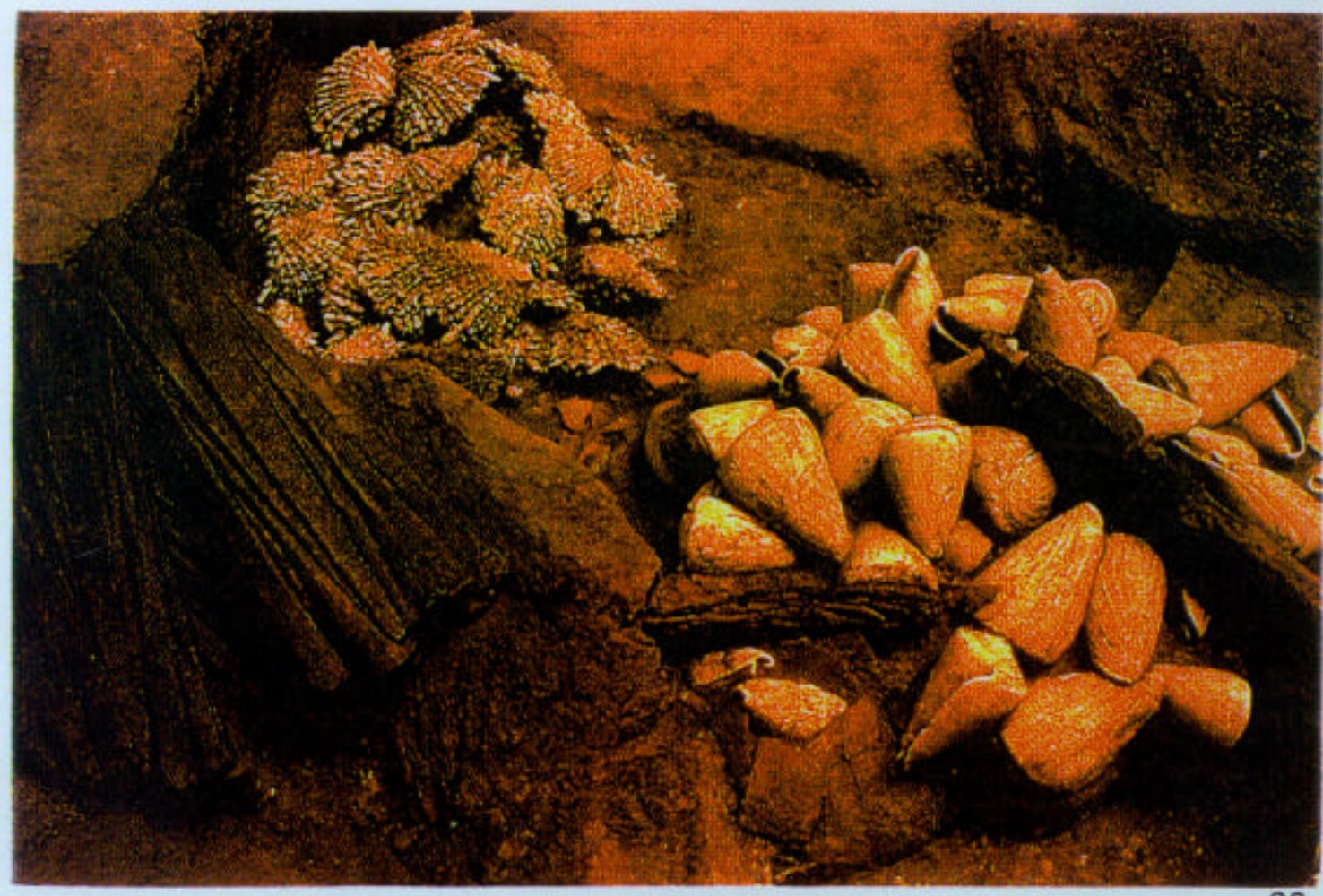

Exemplares de conchas marinhas encontradas em Sicán, norte do Peru.

Fonte: Sicán Project, TBS, 1994-1996: 53 
Recentemente, em pesquisas arqueológicas realizadas em Poquencancha, na periferia de Cuzco, arqueólogos encontraram um enterramento de uma jovem de provavelmente 25 anos com diversos objetos e, entre eles, dezenas de conchas marinhas ${ }^{5}$.

Devido ao fenômeno ambiental El Niño, o Spondylus pode, eventualmente, ser encontrado em Callao (atual porto próximo à Lima). Porém, essa condição era efêmera e por isso não significava uma fonte relevante para os antigos peruanos (Pillsbury, 1996: 317).

O mullu que poderia ser oferecido aos deuses - inteiro ou em fragmentos - podia ser talhado no local de origem com figuras zoomorfas, fitomorfas e geométricas. Segundo a literatura, tinha um alto valor cerimonial e era utilizado muitas vezes em sepultamentos de membros da elite, além de servir como amuleto ou talismã. Era muito famoso por ser considerado como o principal e um dos mais desejados alimentos dos deuses (Masucci, 1995; Hosler, D. et all, 1990).

De acordo com a crença andina, o mullu era indispensável para fazer chover em zonas muito áridas como a zona central andina e, por isso, pode ser considerado um dos fatores da alta demanda dessas conchas. Bartolomé Ruiz, cronista do século XVI, foi o primeiro a registrar as balsas que colocavam em prática o comércio dessas conchas no comércio de longa distância. Em 1525, Ruiz teria se encontrado com uma dessas balsas nas proximidades da costa peruana (Murra, 1975).

Segundo Le Vine (1987), o Spondylus - como parte do sistema econômico e social de troca de presentes - era considerado como fundamental para as bases de poder das políticas andinas e pode ter sido um importante gerador de capital para Estados em expansão. Entre outros itens, pode ter sido utilizado no desenvolvimento e manutenção do relacionamento e status em políticas de expansão.

\footnotetext{
5 France Presse em Arequipa, Peru de 23/08/2001 (http://www.afp.com).
} 


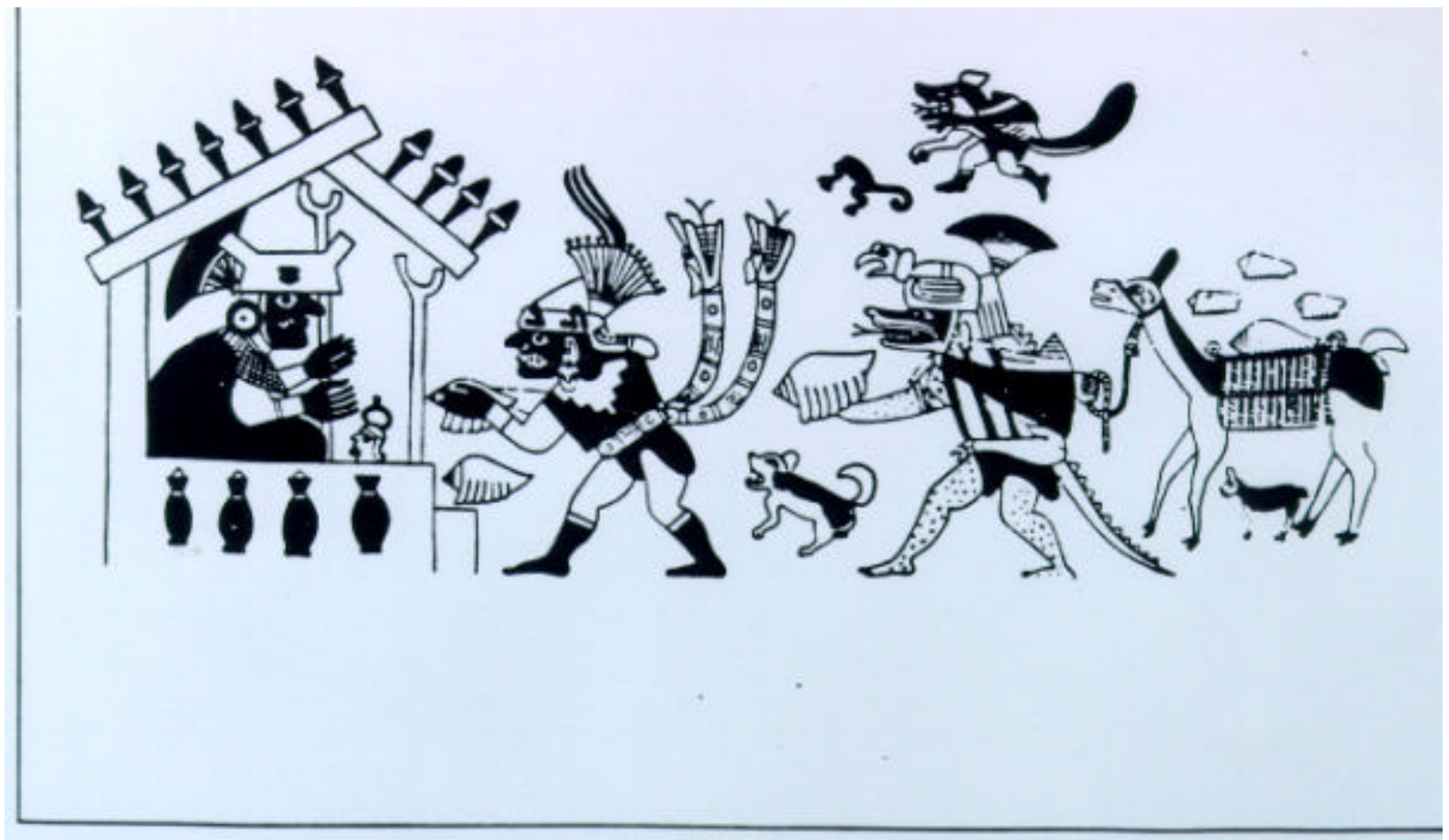

Cena mochica de tributaçẫo e/ou oferecimento de conchas marinhas de tipo Sirombus. Demonstra o uso desse objeto em época anterior ao império Inca.

Fonte: Espinoza Soriano, W. Artesanos, transacciones, monedas y formas de pago en el mundo andino. Siglos $X V$ y XVI. Banco Central de Reserva del Peru. Lima, 1987. Tomo II: 79. 
O achado destas conchas no território do antigo Peru testemunha não apenas o comércio de longa distância - já que eram procedentes de outras regiões - como também a antigüidade deste tipo de comércio. O Spondylus é encontrado arqueológicamente desde o período précerâmico porém, é somente no período Intermediário Tardio (1000 - 1476 A. P.), que ele aparece em grande quantidade (Le Vine, 1987).

Através de escavações arqueológicas realizadas no sítio El Azúcar no Equador, datado em $1750 \pm 60$ A. P., sabemos da existência - em épocas passadas - de um comércio realizado entre a região meridional e a setentrional da costa, em que essa última contribuía com as conchas e a primeira com o cobre. Além disso, foram encontrados muitos objetos no Equador como, por exemplo, cerâmica com motivos associados à região sul da área andina. Outra informação importante que temos graças às escavações do sítio El Azúcar, é que a enorme quantidade de conchas trabalhadas encontradas no local é muito superior à demanda local, o que significa uma produção para fins comerciais, na interpretação da autora (Masucci, 1995).

Por outro lado, escavações arqueológicas realizadas em Isla de la Plata, próxima ao Equador, sugerem que este local servia como um entreposto comercial entre mercadores peruanos, equatorianos e também mesoamericanos até a chegada dos espanhóis, pois neste local foram encontradas conchas e também hachitas de cobre (Lavallée, 1985).

$\mathrm{O}$ alto valor cerimonial e de prestígio destas conchas incentivou enormemente a atividade dos mercadores de longa distância para sua aquisição e/ou posterior troca Há autores que consideram que o controle do tráfico de Spondylus pelos Chimú foi uma das causas da violenta destruição da capital chimorense, Chan Chan, no momento da expansão do Império Inca (Le Vine, 1987).

Em 1621 o cronista espanhol Arriaga afirmava que os índios da costa e mesmo os espanhóis lucravam vendendo estas conchas para os índios da serra e que no início da conquista européia, o Spondylus ainda era freqüentemente trocado (apud Le Vine, 1987). 

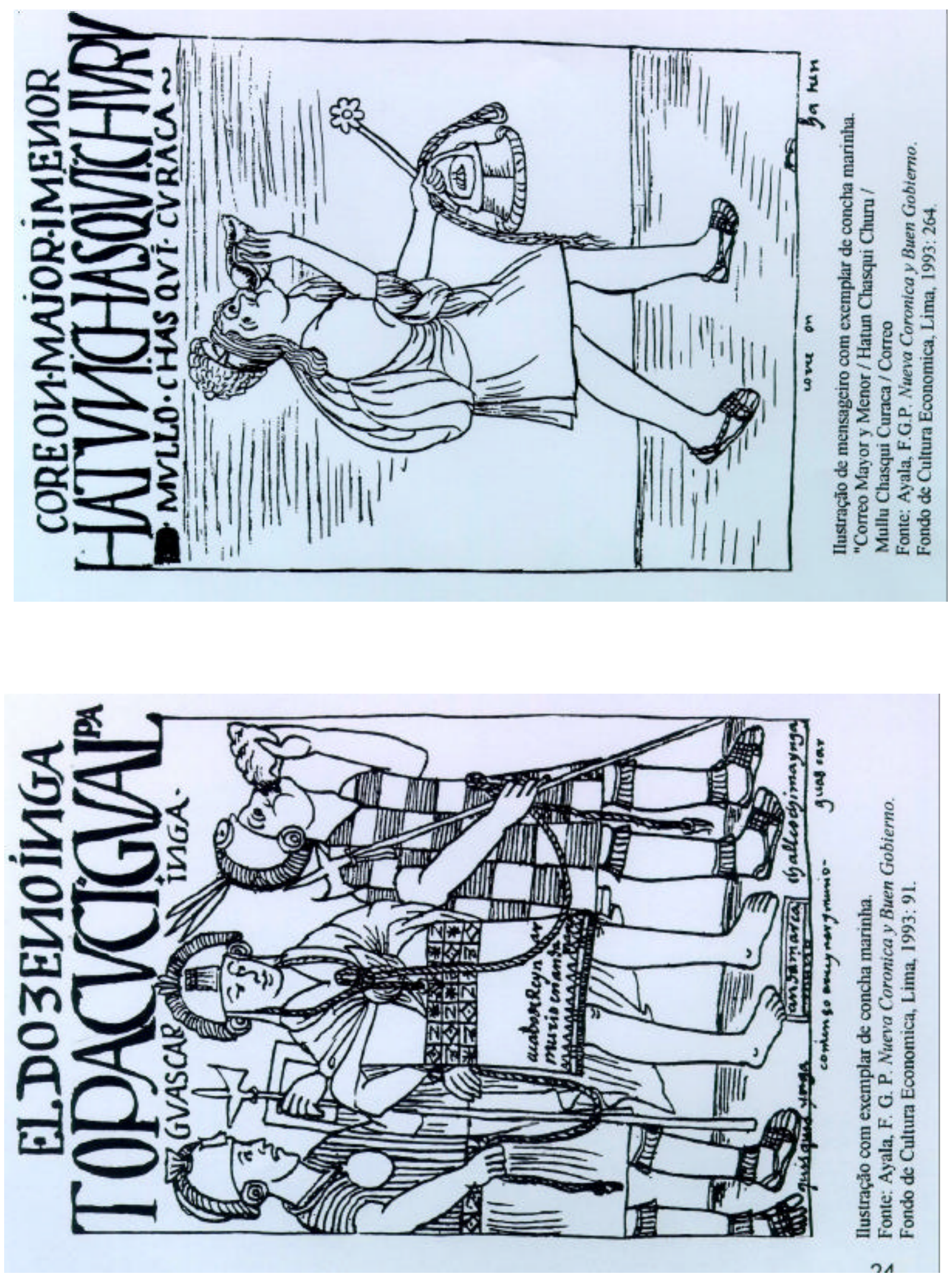
Na região andina estas conchas não mais circulavam de forma intensa pois, como demonstram as escavações arqueológicas, os seus destinos eram os sepultamentos de membros da elite, sacrifícios e oferendas aos deuses (Masucci, 1995).

O mullu também desempenhou um importante papel junto aos mensageiros do império Inca, os chasqui. Esses mensageiros tinham a função de levar notícias e recados aos 4 cantos de Tahuantinsuyu ${ }^{6}$ :

"Corréon de su majestad de este reino que se llama chasqui; hase de saber que el rey Inga tenía de dos maneras de correón en este reino: el primero se llamaba churo mullu chasqui; correón mayor, que de más de quinientas leguas le traían caracoles vivo, que mulo es caracol de la mar de Novo Reino..." (Ayala, 812 / 826: 664).

\subsection{A pimenta do tipo aji}

É um vegetal que até hoje serve como tempero cotidiano no Peru e, antigamente, era utilizado em muitos rituais andinos. Essa pimenta cresce em terras baixas e quentes do Equador até o Chile. Há muitas variedades de ají (Pease, 1988), que abria o apetite, era digestivo, dava excelência aos alimentos, tinha fins medicinais ligados ao estômago e poderia ser transformado em bebidas medicinais e rituais.

No período incaico o aji era produzido através do sistema de mita, mas apenas marginalmente. Há autores que afirmam que em época colonial foi muito usado como

\footnotetext{
${ }^{6}$ O império Inca era dividido em quatro cantos: Chinchasuyu (norte), Collasuyu (sul), Antisuyu (leste) e Contisuyu (oeste). A palavra Tahuantinsuyu significa 'os quatro caminhos'.
} 


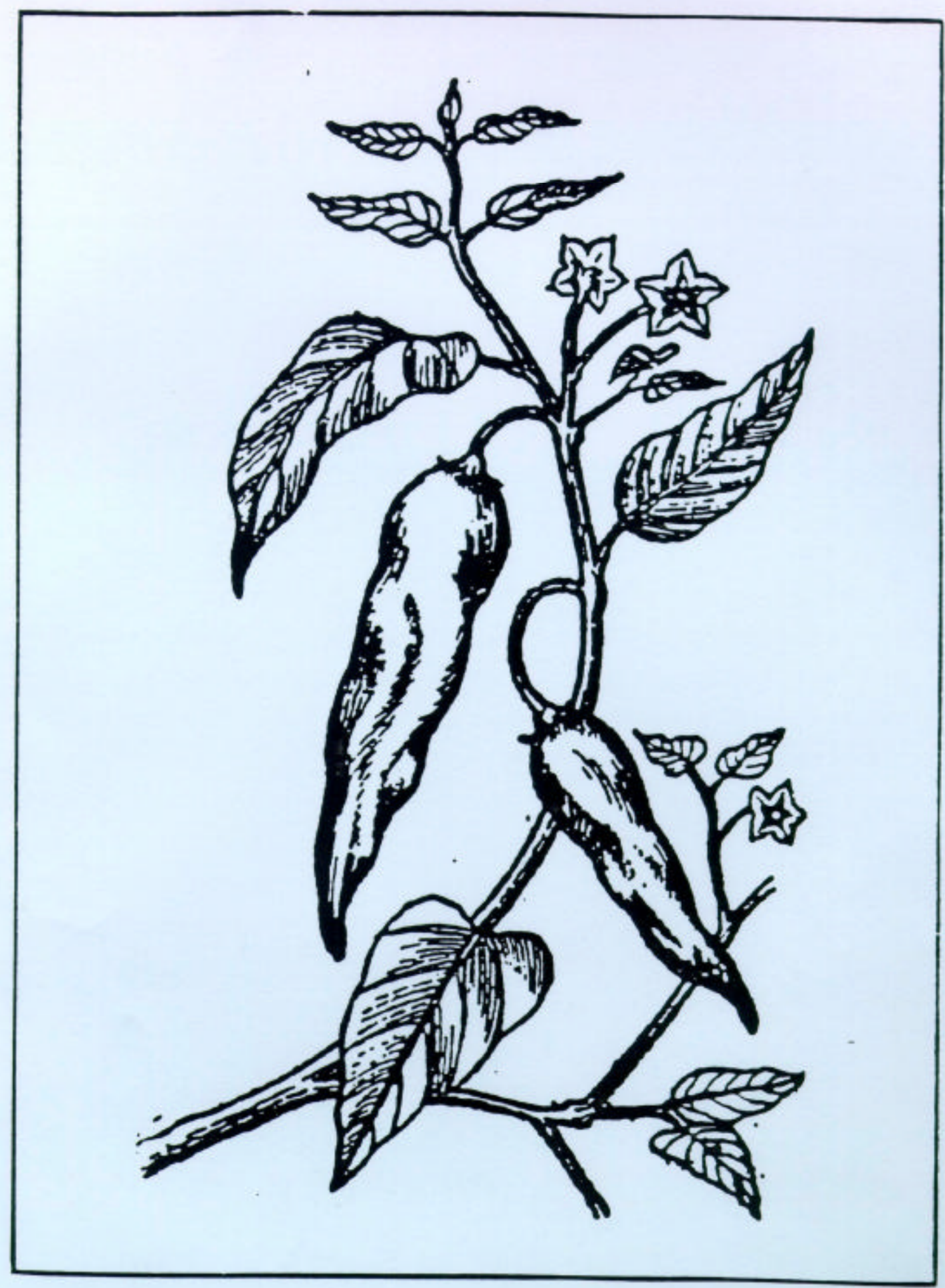

Ramo com frutos de pimenta do tipo ají.

Fonte: ESPINOZA SORIANO, W. Artesanos, transacciones, monedas y formas de pago en el mundo andino. Siglos $X V$ y XVT. Banco Central de Reserva del Peru. Lima, Tomo II, 1987: 98. 
"moeda" pelos indígenas como troco miúdo até o início do presente século, enquanto os colonizadores utilizavam a moeda metálica cunhada espanhola (Pease, 1988).

Para Pease, o ají teve um grande período de vida como produto conversível, isto é, era muito usado como meio de troca e como medida de valor. Sua circulação era bastante intensa e não tinha um destino definitivo como o mullu que ia para sepultamentos e oferendas.

\subsection{As folhas de coca}

O arbusto da coca pertence à família da Eritroxiláceas e pode ser encontrada em 27 espécies. Os antigos peruanos, no entanto, faziam a diferenciação basicamente entre dois tipos de coca. A primeira - a coca tupac - tinha altas porcentagens de alcalóides, qualidade superior e era a mais procurada. A Segunda - a musqui coca - era mais comum e consumida pelas pessoas mais simples, apesar de ser desejada por todos quando faltava a primeira (Espinoza Soriano, 1987: 108).

As folhas da coca contém cocaína e outros alcalóides como, por exemplo, o alucinamil-cocaína e o benzoilecgomina. Sua folha seca pode conter de $0.20 \%$ a $1.03 \%$ de cocaína, porém quando fermentada carece totalmente dessa substância.

No antigo Peru e mesmo nos dias atuais é muito usada por trabalhadores para amenizar a fome, o frio e o cansaço. Mesmo os turistas que visitam o Peru atualmente, fazem uso dessa planta para evitar tonturas e mal-estar quando em altas altitudes.

Em ritos e oferendas era um objeto muito apreciado e era comum queimá-la em honra dos deuses andinos. Segundo Espinoza Soriano (1987: 115-116), os Incas quiseram restringir o acesso e consumo da coca pelas pessoas comuns. Quiseram transformar as folhas de coca em patrimônio exclusivo do Estado. No entanto, o texto Visita de Chucuito de Garci Diez de San Miguel evidencia que os Lupaca (etnia local), mesmo após o domínio Inca, continuaram a 


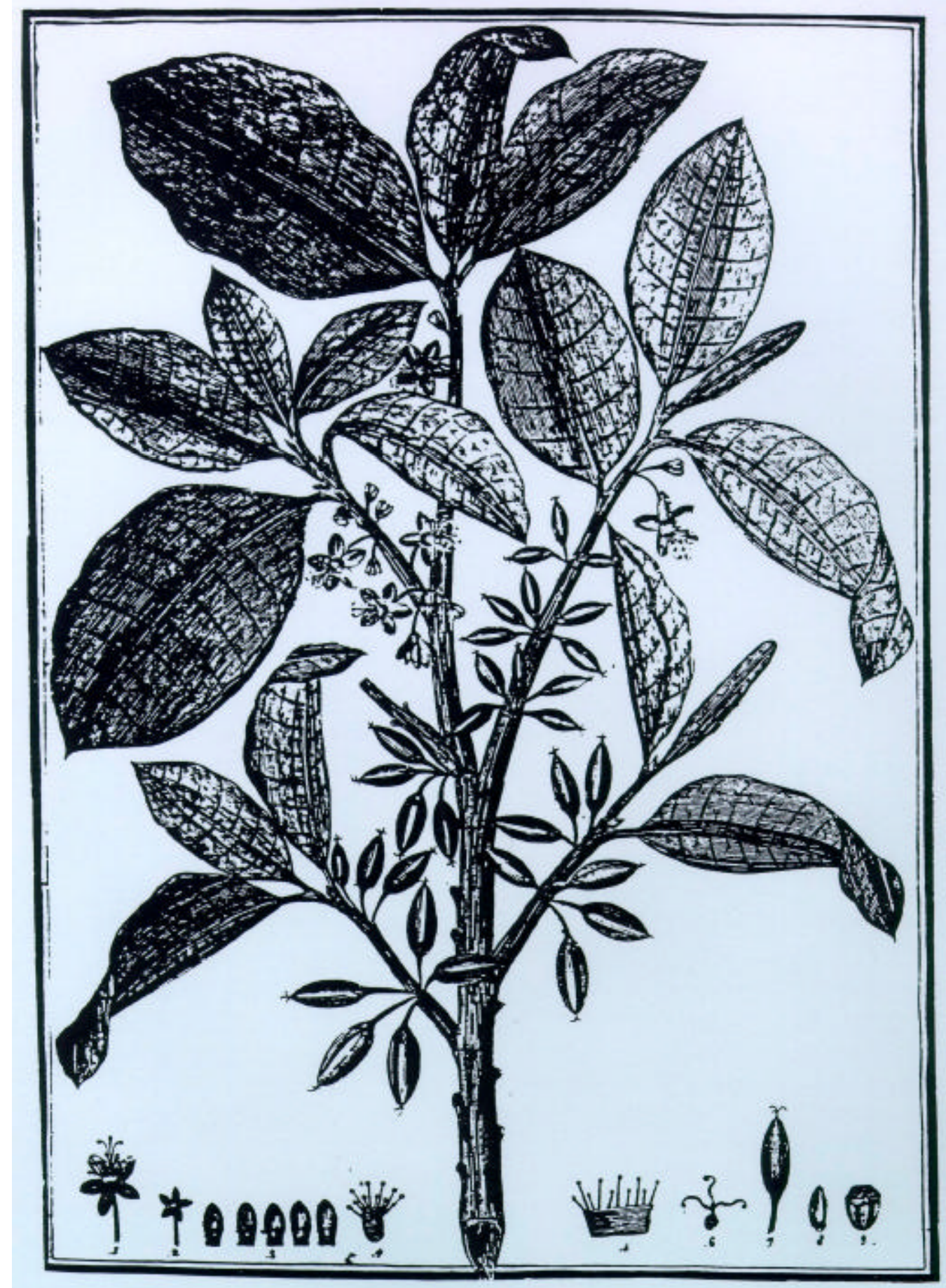

Desenho de ramo de coca impresso em Lima em 1794.

Fonte: Espinoza Soriano, W. Artesanos, transacciones, monedas y formas de pago en el mundo andino. Siglos $X V$ y XV7. Banco Central de Reserva del Peru. Lima, 1987. Tomo II: 110. 
ter acesso à produção de coca local (Diez de San Miguel, 1964 [1567]; Espinoza Soriano, 1987).

\subsection{As Hachitas de cobre, Axe monies e naipes ${ }^{7}$}

São pequenos pedaços de cobre em formato de machadinha, divisíveis e de fácil transporte. As hachitas tiveram um uso intenso na costa norte andina e os habitantes da serra a conheceram somente no período Intermediário Tardio. De acordo com Espinoza Soriano, elas representam o mais alto nível econômico alcançado pela área andina, fato que teria facilitado a sua substituição pela moeda metálica espanhola. No entanto, esta afirmação não está de acordo com os pressupostos teóricos de nossa pesquisa, porque concebe o "dinheiro primitivo" como um situação pré-monetária e dentro de uma linha evolutiva unívoca.

Elas eram fabricadas através da técnica de martelamento, o seu cobre tinha $99 \%$ de pureza. Não se sabe se as hachitas eram confeccionadas por um poder centralizado (Hosler, D. et all, 1990).

Quando descreve os níveis arqueológicos e seus respectivos achados em Batán Grande, Pedersen (1976: 64) relata que "entre os objetos mais surpreendentes encontrados durante a escavação, há uma grande quantidade de lâminas finas de cobre reunidas em 'paquetes' em forma de I e que foram denominadas 'naipes' pelos huaqueros 8 que até então nunca haviam encontrado esse tipo de material". Pedersen recolheu vários 'paquetes' "que se encontravam abandonados no lugar, possuindo cada um deles até 500 lâminas, todas ordenadas e enganchadas entre si de uma maneira especial, formando blocos compactos".

\footnotetext{
${ }^{7}$ Há autores (Hosler, Lethtman e Holm, 1990), que diferenciam hachitas de naipes. As primeiras referem-se a pequenos pedaços de cobre em formato de machadinho, sendo que os naipes referem-se a pequenos pedaços de cobre em formato de I. As hachitas são encontradas com maior freqüência no extremo norte do Peru enquanto que os naipes são encontrados em sítios arqueológicos ao norte do Peru. Apesar da diferença de formato, todas as outras características se mantém idênticas por isso, muitas vezes a bibliografia sobre o tema refere-se a esses materiais genericamente como hachitas ou naipes.

${ }^{8}$ Pessoas que saqueiam sítios arqueológicos para fins comerciais.
} 


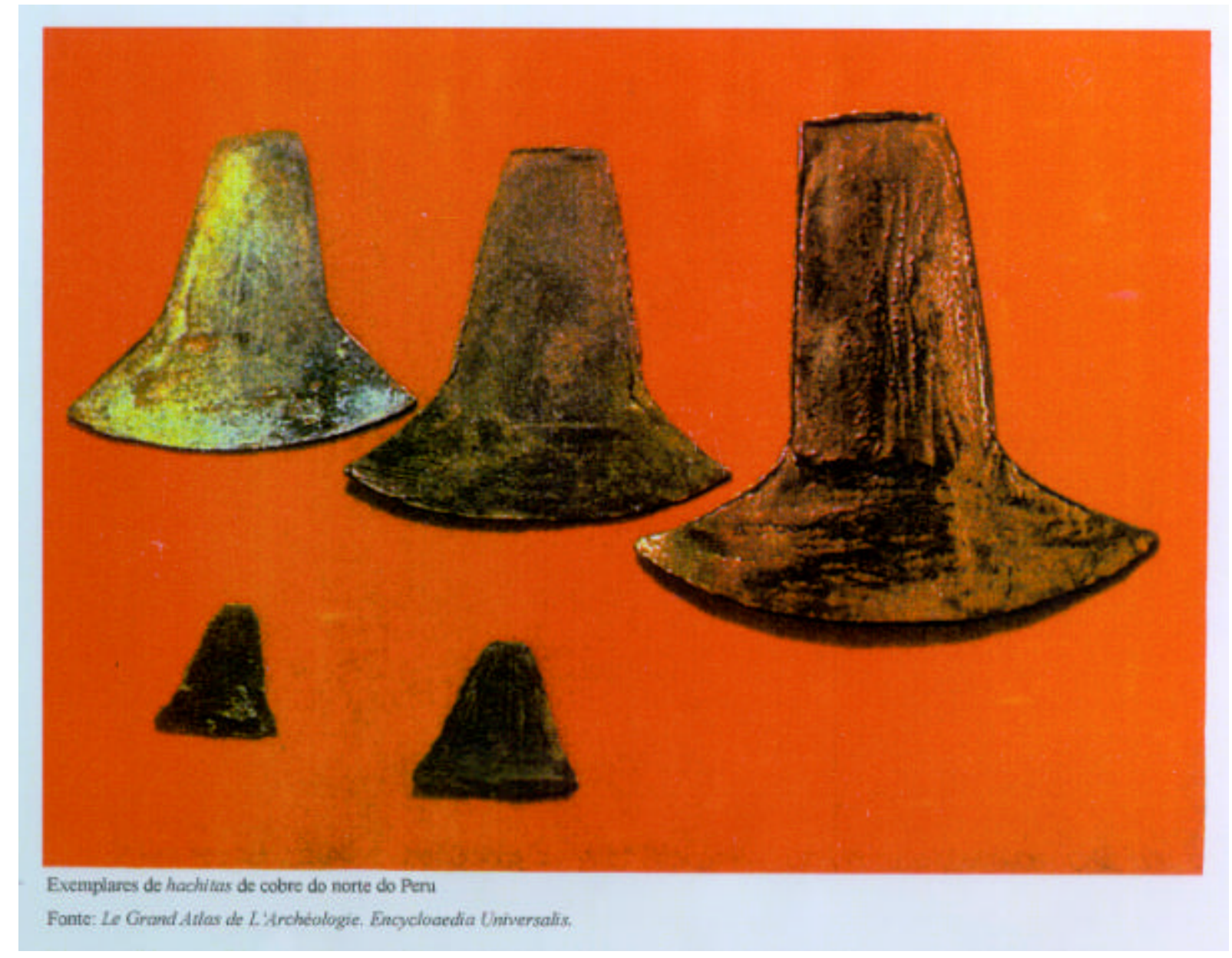


Entre os cronistas do século XVI, há poucas menções sobre as hachitas de cobre e isto pode ser compreendido se considerarmos que para os espanhóis apenas o ouro e a prata tinham valor - ou seja - não estavam interessados em metais pouco valiosos como o cobre (Lavallée, 1985).

As hachitas foram encontradas em diversos sítios arqueológicos no Peru e no Equador: La Puna, Paches, Chono, Lambayeque, Huancavilca, El Oro, Manabí, Los Rios, Guayas, entre outros. São geralmente associadas a contextos arqueológicos datados de 800 e 1.500 d. C. Nestes sítios, são encontradas na maior parte das vezes em contextos cerimoniais (santuários), como por exemplo, em Santa Elena no Equador: 13.000 hachitas de cobre em uma única sepultura! (Espinoza Soriano, 1987). Além de contextos funerários, como em Sícan (9001100 A. D.), no litoral norte do Peru, local onde foram encontradas em enterramentos de pessoas da elite, mais de 20 mil unidades de hachitas.

Merkel (2000), após análises físicas e químicas, descartaram o uso desses objetos como instrumentos ou armas pois, o metal não era apropriado para desempenhar essas funções. A borda grossa e a fragilidade das hachitas são fatores que colaboram para a tese de que, por um lado elas não tinham utilidade alguma como instrumentos; e por outro lado fortalece a idéia de que poderiam ter servido como uma forma de "dinheiro primitivo".

Para eles, as hachitas funcionavam como uma forma de dinheiro primitivo: "evidências do uso dos naipes como um meio de pagamento para materiais exóticos podem ser inferidas por meio da distribuição geográfica dos naipes" (Merkel, J. F. et all, 2000). 


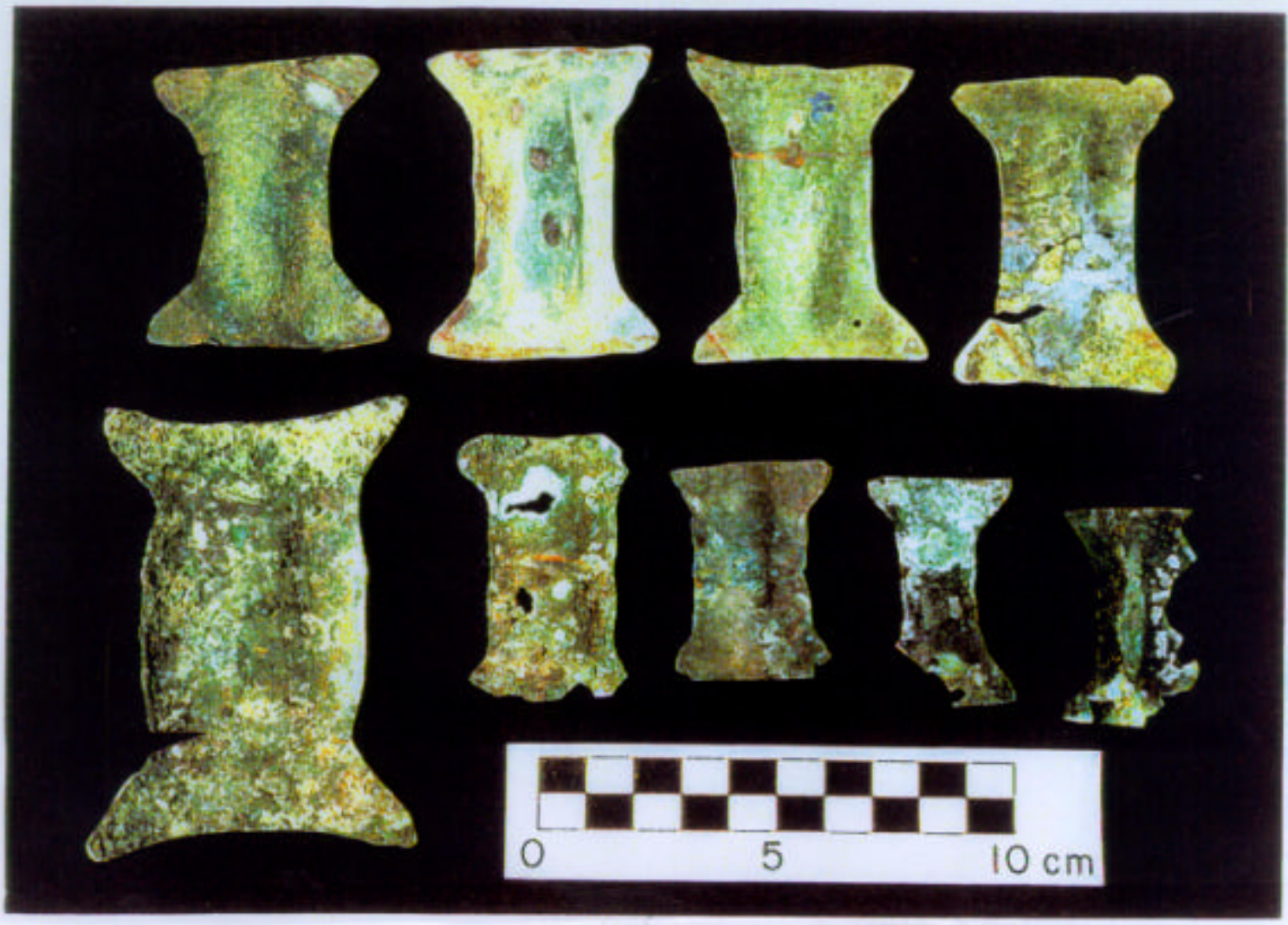

Exemplares de hachitas (naipes) de cobre encontrados em Sicán, norte do Peru. Fonte: Sicán Project, TBS, 1994-1996: 148.

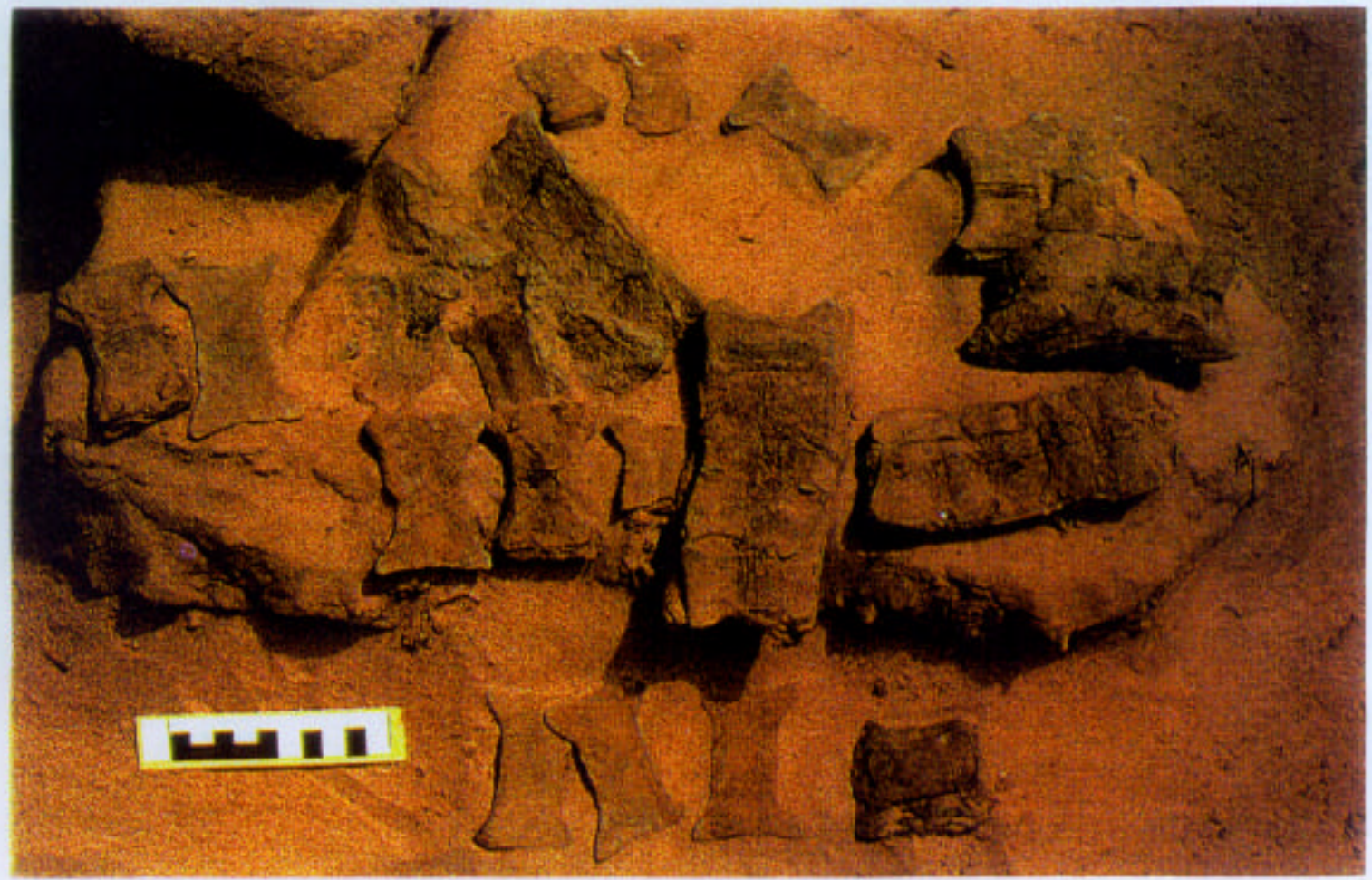

Paquetes de hachitas (naipes) de cobre encontrados em Sicán, norte do Peru.

Fonte: Sicán Project, TBS, 1994-1996: 148. 


\section{CAPÍtULO 2 \\ CONCEPÇÕES TEÓRICAS ACERCA DO "DINHEIRO PRIMITIVO"}

Foi no início dos anos 60 - principalmente nos EUA e na França - que uma disciplina recém-nascida chamada Antropologia Econômica começou a estudar e a se preocupar com as atividades econômicas das sociedades antigas. Até então - apesar de trabalhos pioneiros como os de Bronislaw Malinowski (1922) e de Marcel Mauss (1924) - não havia sido dado atenção de forma sistemática à esfera econômica dos povos arcaicos e, quando isto ocorria, geralmente resultava em tentativas anacrônicas de estender ao passado as regras econômicas do presente. A ciência antropológica dos anos 60, no entanto, já tinha idade e experiência suficientes para entender que as ferramentas teóricas para compreensão da moderna sociedade capitalista não poderiam ter a mesma eficácia no estudo das sociedades anteriores.

No entanto, as coisas não fluíram tão logicamente assim e, alguns pesquisadores insistiam - e ainda insistem - em transportar para o mundo antigo conceitos procedentes da moderna economia e, principalmente, do marxismo como, por exemplo, os conceitos de valor de uso e modo de produção.

Estava criada dentro da antropologia econômica a divisão - principalmente nos Estados Unidos - entre formalistas e substantivistas. Os primeiros tentando exaustivamente encontrar traços e características modernas nos antigos, e os substantivistas - por sua vez encaminhando-se para o sentido contrário na tentativa de dar à economia dos povos antigos um caráter específico e particular.

Do ponto de vista formalista, representado por autores como Firth, Herskovits e Goodfellow, não há - de fato - nenhuma diferença entre economia antiga e moderna: ao considerar que através da universalidade do sujeito racional, tornado sujeito econômico racional, manifesta-se a perenidade dos mecanismos da economia burguesa e a tarefa do 
antropólogo consiste em encontrar nas sociedades que estuda a sua promessa ou, inversamente, o seu traço (Démonio, 1976:32).

Essa perspectiva aniquila os esforços da antropologia, construída para elucidar a diversidade dos modos de existência humanos. A antropologia, por meio desse raciocínio, se vê obrigada a reduzir as diferenças a fim de atingir esse nível abstrato em que o sujeito, carente de toda a determinação, parece universal (Démonio, 1976: 32).

Um ponto central da abordagem formalista é a crença de que as relações de produção que regem a sociedade capitalista são fundamentalmente da mesma natureza que as que governam as diversas sociedades estudadas pelos antropólogos (Démonio, 1976: 47).

Para os formalistas, a economia é definida como o estudo da relação entre fins e meios escassos que possuem usos alternativos, quer dizer, o aspecto social do processo econômico (produção, circulação, distribuição em condições determinadas) desaparece, em proveito de uma relação lógica (formal) que não diz respeito às relações entre grupos mas a um comportamento, dito comportamento de escolha racional, efetuado em função do princípio conhecido pelo nome de cálculo de maximização (Démonio, 1976: 48), ou seja, a lei do mínimo esforço.

A partir da abordagem formalista a ciência antropológica parece não ter se desvinculado de sua infância imperialista do século XVI, quando as sociedades extraeuropéias eram "entendidas" por meio da visão de mundo do velho continente. Mas, neste caso, todos nós já compreendemos que o conquistador europeu da época dos descobrimentos não tinha condições de agir como se fosse um antropólogo do século XX. Porém, no caso dos formalistas trata-se de insistir em uma postura etnocêntrica ainda e as explicações que - por diversos motivos - foram úteis aos conquistadores não servem para uma antropologia amadurecida e elucidativa de hoje. 
A partir da abordagem substantivista da economia - liderada pelo húngaro Karl Polanyi - a antropologia foi restituída à sua vocação de observação de sociedades concretas, na medida em que esta mesma análise deixa transparecer a diversidade das relações sociais e, por meio dela, a diversidade das relações econômicas e de sua representação (Démonio, 1976: 32).

A análise substantivista, por sua vez, refuta o sistema universal dos formalistas e nega qualquer interpretação etapista, propondo em seu lugar o estudo da diversidade da instituição econômica no seio das diferentes sociedades.

O estudo do "dinheiro primitivo" não fica à margem desta discussão, pois chegaremos em diferentes e opostas concepções acerca dos objetos que desempenhavam o papel de "dinheiro primitivo" à medida que nos aproximamos de uma ou de outra abordagem. Seguindo o raciocínio formalista, o "dinheiro primitivo" é um elemento a mais no interior de uma trajetória pré-estabelecida e unilinear. Formalistas tentam enxergar no "dinheiro primitivo" características típicas do dinheiro moderno e ficam muito satisfeitos quando conseguem encaixar os objetos que nas sociedades antigas - em maior ou menor grau desempenhavam um papel diferenciado dos demais, dentro da lógica universal e evolucionista.

No caso dos substantivistas, a tendência é diametralmente oposta, pois trata-se de estudar as especificidades e particularidades do "dinheiro primitivo" no interior de um sistema que era regido por estatutos próprios e sem tentativas anacrônicas de inserir esses objetos dentro de uma escala de valor etnocêntrica e evolutiva.

\subsection{Karl Polanyi e a economia embedded}

A principal contribuição e mérito de Polanyi - expoente e maior representante da abordagem substantivista da economia - está na idéia de que a análise das economias antigas 
demanda uma conceituação diferente das economias modernas e contemporâneas, ou seja, é errôneo a aplicação de conceitos da economia contemporânea às sociedades não capitalistas e é preciso o uso de instrumentais teóricos de análise diferenciados para o estudo das sociedades antigas. Isto é, não é possível a utilização dos mesmos conceitos para análise das economias modernas, sejam utilizados também no estudo das economias arcaicas.

Para a melhor compreensão da economia antiga, o autor trabalha com dois conceitos básicos: a economia "embedded" e economia "desembedded"9. Segundo o autor nas sociedades não mercantis até o século XIX, a economia era de tipo "embedded", ou seja, encaixada nas relações sociais. Os comportamentos econômicos correspondiam a motivações muito mais sociais que econômicas. Após esse período, as economias européias tornaram-se desencaixadas, ou seja, com um grau maior de autonomia em relação as demais esferas. Dessa forma, a economia ao organizar-se em grande parte sobre as bases do mercado, separou-se significativamente das demais instituições sociais, obrigando o restante da sociedade a funcionar sob suas leis (Polanyi, 1957: 10). Entenda-se economia autônoma ou desencaixada como uma esfera social que influencia as demais em uma escala muito mais significativa que nas economias antigas, mas não como um fator determinante.

O que Polanyi propõe - como uma das metas da antropologia econômica - é que se estude o lugar da economia no seio das sociedades, o que não é mais que o estudo da maneira de como o processo econômico se institucionaliza em diversos tempos e lugares. Antes dele, outros autores trataram dessas questões no entanto, para esses autores a economia encaixada seria uma etapa anterior às economias desencaixadas, ou seja, corresponderiam a estágios sucessivos de uma possível evolução econômica da sociedade. Para Polanyi, isso é

\footnotetext{
${ }^{9}$ Esses termos têm sido traduzidos para o português como economia "encaixada" e "desencaixada", ou então por economia "engastada".
} 
conseqüência da diversidade da história das sociedades, jamais um estágio ou etapa a ser superada.

Segundo a interpretação substantivista da economia adotada por Polanyi, o processo institucionalizado de interação entre o homem e o meio ocorre de maneira continuada, sendo que o homem faz uso dos meios materiais para satisfazer suas necessidades. Entenda-se por instituição as relações sociais gerais dos homens entre si em uma sociedade dada (Polanyi, 1957: 15).

Há dois tipos de economia para o autor, a Real e a Formal. A primeira não implica na eleição e nem na escassez de recursos, ou seja, não há escassez e trata-se de uma economia empírica, em que há a atividade institucionalizada de interação entre o homem e seu meio. Neste caso, a atividade econômica atua como um fenômeno natural e social. Na economia Formal, existem normas que regem a eleição entre os usos alternativos de meios escassos e os indivíduos adaptam sua conduta de modo a alcançar o modo mais eficaz por meio do esforço mínimo (Démonio, 1976: 48).

O processo econômico para Polanyi exige para funcionar a presença de formas de integração - reciprocidade, redistribuição e comércio - que conduzem à sua institucionalização por intermédio de suportes institucionais. Estas formas de integração não têm, de fato, nada em comum com a realidade econômica existente numa dada sociedade e variam conforme cada uma delas (Démonio, 1976: 55).

A reciprocidade supõe movimentos entre pontos correlativos de agrupações simétricas. Os fatores que favorecem esse tipo de interação são o dualismo dos grupos de parentesco e a distribuição das tribos por segmentos iguais. A reciprocidade intervém tanto na produção (prestações de serviço, abonações periódicas das terras), como também na repartição dos produtos através de oferendas e contra-oferendas, das distribuições cerimoniais de alimentos, etc (Valensi, 1974: 17). 
Já a redistribuição pressupõe um modelo institucional de centralização no qual a produção e a repartição dos bens são organizadas em função de um centro - quer se trate de um chefe, de um senhor, de um templo, de um déspota ou de um Estado - que coleta, armazena e redistribui os produtos a fim de retribuir os seus agentes e assegurar a manutenção e a defesa dos serviços comuns, assim como a preservação da ordem social e política, inclusive, por exemplo, quando do consumo ostentatório por ocasião das festas públicas (Valensi, 1974: 18).

Finalmente, o comércio - definido por Polanyi como um método relativamente pacífico de aquisição de bens que não podem ser encontrados num mesmo local (apud: Meunier, 1976: 228) - requer movimentos recíprocos, como os que realizam os sujeitos em um sistema de mercado. Para isso necessita de um mercado criador de preços.

É importante colocar que essas três formas de integração não representam etapas de desenvolvimento, pois não implicam em nenhuma ordem de sucessão no tempo. O que pode ocorrer são predominâncias e também a simultaneidade dessas formas de integração como no caso dos Incas em que o sistema redistributivo oficial convivia perfeitamente com a reciprocidade e com o comércio.

No que se refere ainda às economias arcaicas há o que Polanyi denominou port of trade ou porto de comércio. O porto de comércio é, em primeiro lugar, externo e relaciona entre si diferentes conjuntos ecológicos, economias mercantis e não mercantis, mercadores profissionais e estrangeiros. Responde às necessidades militares e políticas do Estado e é centralmente administrado (Valensi, 1974: 19).

Polanyi propõe uma análise separada de trocas comerciais, dinheiro e mercado. Para ele, o mercado não é necessariamente o lugar do intercâmbio, e nem todo dinheiro é para troca, ou seja, comércio e dinheiro nem sempre significam interação baseada no intercâmbio: "Existe uma aceitação mais ou menos tácita, de que quando existe comércio (trocas 
puramente comerciais), deve haver relações de mercado, e quando aparece o dinheiro se deduz a existência do comércio, e por consequiência de mercado. Naturalmente, esse raciocínio leva-nos a ver mercados onde não há, e a ignorar a existência do comércio e do dinheiro quando não se pode provar que atuam em um marco de mercado" (Polanyi, 1957: 303).

O uso do dinheiro como meio de troca surge da necessidade de objetos quantificáveis para o intercâmbio indireto. E a principal função do dinheiro é a de meio de pagamento e de padrão de valor. A função do dinheiro como instrumento de troca não é anterior às suas outras funções e pode resultar apenas de fins políticos, sociais e religiosos e não, exclusivamente, das necessidades do mercado (Polanyi, 1957: 310).

O comércio é entendido pelos substantivistas como uma atividade não individual em que interagem quatro elementos: 1 . o mercador (o bom mercador é aquele que age pela honra e pela moral, e não pelo lucro); 2. a mercadoria (a especificidade do comércio está extremamente relacionada com a necessidade de adquirir produtos importados por meio de outros exportados, pois quando a economia não está regida pelo mercado, as importações e as exportações tendem a estar submetidas a regimes distintos); 3. o transporte (tem tanta importância quanto os demais elementos) e; 4. a bilateralidade (neste caso podemos observar três tipos de comércio: de presentes, administrativo e mercantil).

O comércio de presentes une as partes por relações de reciprocidade. Neste caso os objetos de troca são objetos de luxo e de prestígio. Já o comércio administrativo se baseia em tratados mais ou menos formais e pode haver a existência de canais controlados pelo governo, como por exemplo, mercadorias padronizadas. O local por excelência onde ocorre esse tipo de comércio é o porto de comércio que oferece segurança e proteção militar. E, finalmente o comércio mercantil em que os intercâmbios estão na forma de integração que relaciona as partes entre si (Polanyi, 1957: 308-309). 


\subsection{Marcel Mauss e a teoria da reciprocidade}

Em Ensaio sobre a dádiva: forma e razão da troca nas sociedades arcaicas, de 1924,

Marcel Mauss estava preocupado em estudar as trocas nas sociedades ditas primitivas e arcaicas e para tanto, utilizou-se dos trabalhos etnográficos de Bronislaw Malinowsky, Franz Boas e outros, sobre povos do noroeste americano, da Polinésia e da Melanésia.

Sua principal idéia baseava-se em que as trocas nas sociedades antigas não se limitavam em ser trocas simples de produtos úteis economicamente: “o que trocam não são exclusivamente bens e riquezas, móveis e imóveis, coisas economicamente úteis. Trata-se, antes de tudo, de gentilezas, banquetes, ritos, serviços militares, danças, festas..." (Mauss, 1974: 45). A isso, Mauss nomeou sistema de prestações totais, que por sua vez tem algumas características fundamentais que são: em primeiro lugar a idéia de que nesse sistema as trocas não são feitas individualmente: “...não são indivíduos, e sim coletividades que se obrigam mutuamente, trocam e contratam, as pessoas presentes ao contrato são pessoas morais - clãs, tribos, famílias - que se opõem...” (Mauss, 1974: 44). Em segundo lugar aparece a questão das diferentes esferas sociais que estão presentes nessas trocas, ou seja, nas trocas "primitivas" se expressam ao mesmo tempo diferentes esferas da sociedade como, por exemplo, a economia, a moral e a religião. É como se toda a sociedade estivesse ali presente. Isso nos mostra que nas sociedades antigas a economia não era uma esfera autônoma independente das demais, como ocorre em uma escala significativa em nossa sociedade atual. Finalmente, em terceiro lugar, Mauss caracteriza a troca de presentes como sendo obrigatória, apesar de parecer o contrário: “...essas prestações e contraprestações são feitas sobretudo de uma forma voluntária, por presentes, embora sejam no fundo, rigorosamente obrigatórias sob pena de guerra privada ou pública" (Mauss, 1974: 45). Porém, é importante que a aparente voluntariedade seja respeitada para que permaneça o crédito, a confiança do homem no homem (Lefort, 1967). 
A partir do conceito de prestações totais, como apresentado acima, Mauss apresentanos o Potlatch, que seria uma forma mais aprimorada do sistema de prestações totais, e que o autor também chama de prestações totais de tipo agonístico.

O Potlatch se diferencia das demais categorias, principalmente pelo fato de que nas tribos que o praticavam há uma determinada rivalidade presente, ou seja, o Potlatch tem um aspecto agonístico, usuário e suntuário bastante acentuado em que, como escreveu Mauss “...assiste-se uma luta dos nobres para assegurar entre eles uma hierarquia que resultará em proveito de seus clãs..."(Mauss, 1974: 47). O valor do prestígio e da honra que se liga ao Potlatch é tão grande que em certos casos clãs se lançam desafios e procuram explicitamente a submissão do adversário. Chega-se até à própria destruição das riquezas.

Em certos casos deve-se mesmo gastar tudo e não guardar nada. Aquele que soube tudo consumir e tudo destruir é visto pelos outros como chefe. Sobre isso, Mauss mostrou como podemos encontrar em graus diversos essas práticas relativas ao Potlatch em muitas regiões do mundo.

Assim sendo, segundo Mauss, nesse complexo sistema de troca de presentes - o Potlatch - a honra e o prestígio têm um papel fundamental que regem três momentos de igual importância: a obrigação de retribuir, de dar e de receber.

Para provar que são favorecidos pelos espíritos e pela fortuna, um chefe deve dar suntuosamente. Somente gastando sua fortuna é que consegue manter sua posição e autoridade frente aos demais. Quanto mais suntuosamente distribuir sua riqueza, mais será reconhecido e respeitado: “...o Potlatch, a distribuição de bens, é o ato fundamental do reconhecimento militar, jurídico, econômico e religioso, em todos os sentidos do termo" (Mauss, 1974: 109). 
Recusar um presente pode ser tão maléfico quanto não presentear, pode mesmo gerar um conflito. O indivíduo que nega um presente dado, declara que tem medo de retribuir, pois aceitar é comprometer-se a retribuir.

Retribuir um presente com juros, por sua vez, é o que geralmente acontece no Potlatch. Para se obter ou manter o prestígio, no entanto, quando se deseja humilhar o parceiro ou obter maior poder, o mais usual é mesmo a destruição das riquezas.

Dito de outra forma, aquele que recebe um presente de outro deve, em primeiro lugar, aceitá-lo, pois a ação de não aceitar um presente demonstra medo e fraqueza de não poder retribuir em igual tamanho, ou de preferência com maior suntuosidade. Ou seja, a prática do dom e do contra-dom funciona em um crescendo em que quem retribui sempre o faz de uma forma mais suntuosa com o intuito de ganhar honra, prestígio e poder. Assim sendo, a moral fica ao lado daqueles que tudo dão e não são mesquinhos. E, como mencionado, chega-se até mesmo à destruição dos presentes. Sobre isso Mauss escreveu "em nenhuma parte o prestígio individual de um chefe e o prestígio de seu clã encontra-se mais ligado ao gasto, bem como a exatidão de retribuir usurariamente as dádivas aceitas, de modo a transformar em obrigações os que antes obrigavam. O consumo e a destruição são aqui realmente ilimitados. Decide-se quem será o mais rico e também o esbanjador mais desatinado” (Mauss, 1974: 98-99).

Há ainda por trás do Potlatch e de suas três obrigações, outros dois elementos essenciais para sua compreensão que são as idéias de hau e mana.

O mana é uma palavra procedente da Polinésia que denota magia. "É o elemento da honra e do prestígio que confere riqueza e o da obrigação absoluta de retribuir as dádivas sob pena de perder esse mana, essa autoridade, esse talismã e essa fonte de riqueza que é a própria autoridade" (Mauss, 1974: 50).

O hau é um conceito de origem Maori (grupo nativo da Nova Zelândia), que Mauss utiliza para fazer compreender o fator de obrigatoriedade nas trocas de presentes. 
Essencialmente, o hau é o espírito das coisas: “...todas as propriedades rigorosamente ditas pessoais têm um hau, um poder espiritual. Você me dá uma delas e eu a dou a um terceiro, este a retribui com uma outra porque é impelido pelo hau de meu presente e, quanto a mim, sou obrigado a dar-lhe essa coisa, pois é preciso que eu lhe devolva aquilo que na verdade é produto do hau. No fundo, é o hau que quer regressar ao local do nascimento, ao santuário da floresta e ao clã do proprietário" (Mauss, 1974: 54-55).

Sobre o hau, ainda pode-se dizer que constitui um dos fundamentos da análise de Mauss, que é o caráter compulsivo da reciprocidade, ou seja, é o "espírito do objeto" que faz com que os presentes circulem incansavelmente.

Por toda complexidade e amplitude que os fenômenos constituintes do Potlatch representam, Mauss os nomeia de fato social total em que "toda a sociedade parece estar presente" e onde as várias dimensões da realidade social aparecem articuladas e interdependentes. Dessa forma, o Potlatch é, ao mesmo tempo, um fenômeno jurídico, religioso, mitológico, xamanístico, econômico e é também um fenômeno de morfologia social já que reúne diferentes noções em torno de um mesmo evento.

São fatos sociais totais porque colocam, na maioria dos casos, toda a sociedade em movimento. São fatos sociais totais porque não abarcam apenas uma instituição ou parte dela, mas sim sistemas sociais inteiros.

Com essa categoria de fato social total, Mauss nos oferece o princípio metodológico segundo o qual há fatos sociais estratégicos, a partir dos quais o analista deve descortinar mecanismos que revelariam a sociedade como uma "totalidade coerente" e em atividade.

Com Ensaio sobre a dádiva, Mauss parece perceber que por trás dos desafios morais das trocas do Potlatch, há uma estrutura de equivalência entre os homens expressada na reciprocidade e em sua compulsividade (receber, dar e retribuir). Como se essa reciprocidade através da circulação de presentes, fosse o que garantisse a sociedade em si, como se a troca 
servisse de base para a interação social (Blau, 1974). Como se as trocas, através da reciprocidade, funcionassem como o mecanismo que regula as relações entre os homens.

As categorias trabalhadas por Marcel Mauss de sistema de prestações totais de tipo agonístico ou Potlatch, mana e hau, têm um grande proveito para o entendimento da reciprocidade andina conforme suas proporções. Porém, sempre lembrando que não se trata de uma transposição mecânica das idéias de Mauss para o caso andino, mas apenas a reflexão acerca das suas propostas e categorias de análise que podem se tornar um exercício teórico muito proveitoso.

Da mesma forma que as sociedades estudadas por Mauss, a sociedade andina dos séculos XV e XVI não se encontrava em uma economia de mercado com um sistema de preços e com moedas (no sentido atual do termo).

A teoria da reciprocidade tal como tratada por Mauss pode ser considerada universal, principalmente quando se trata de sociedades arcaicas. No entanto, não poderíamos deixar de descartar de forma alguma o alcance de suas idéias até mesmo em nossa sociedade atual, mas em um grau bem menor que nas sociedades antigas.

\subsection{Categorias weberianas para análise das economia antigas}

Ao tratar dos elementos mais básicos inerentes à economia antiga, Max Weber faz uma clara distinção entre meios de troca, meios de pagamento e dinheiro.

Para o autor meio de troca é um objeto que, de modo genérico, isto é - reiteradamente e em grande escala - é admitido em troca por um círculo de pessoas, somente pela razão que se espera também poder dar em troca. E não necessariamente os meios de troca e os meios de pagamento resultam ser idênticos. Para o autor, meio de pagamento é somente um elemento genérico que permite realizar determinadas prestações como, por exemplo, o pagamento de dívidas; porém nem todas as dívidas correspondem a operações de troca, como ocorre no caso 
de dívidas fiscais e tributárias. Por outro lado, não é qualquer meio de pagamento que se apresenta na história da economia que é meio de troca; por exemplo, na África, as vacas funcionavam como meio de pagamento mas não como meio de troca, as mulheres não podiam ser adquiridas com moedas de concha, mas somente com vacas. Assim sendo, nem todo meio de troca é - de modo ilimitado - meio de pagamento na área onde tem validez como tal. Os Khanes mongóis fizeram circular entre seus vassalos moedas de papel que não admitiam como meio de pagamento de impostos. Na Áustria, determinadas moedas de ouro somente se usavam em certas épocas, para o pagamento de direitos de aduana. Ou seja, nem todo meio de troca foi utilizado na história como um meio para todas as modalidades de troca (Weber, 1964: 6).

Para o raciocínio weberiano portanto, dinheiro é um meio de pagamento que, ao mesmo tempo, se utiliza como meio de troca dentro de um determinado círculo de pessoas e que, dotado de um valor nominal (por meio das acunhações), está em condições de servir também como unidade de conta.

O autor faz ainda uma diferenciação entre economia natural e economia monetária, na qual, a economia natural não conhece o uso do dinheiro, e pode ser uma economia cujas necessidades ficam satisfeitas sem que se recorra à troca, como ocorre, por exemplo, com o senhor territorial que faz descansar a satisfação de suas necessidades sobre as economias das fazendas agrícolas dos lavradores ou, como ocorre com o oikos, a economia doméstica fechada na antiga Grécia. No entanto, em sua forma pura, sempre reveste um caráter excepcional. Também pode ser uma economia natural de troca, na qual, apesar de encontrarmos a troca econômica, não aparece o dinheiro. Esta forma econômica nunca chega a adquirir pleno desenvolvimento. No antigo Egito predominou durante algum tempo uma economia que calculava em dinheiro e trocava em espécie, trocando quantidade de bens 
contra quantidade de bens, depois de fazer uma estimativa prévia em dinheiro, de ambas quantidades (Weber, 1964: 7).

Na economia monetária, é possível uma separação pessoal e temporal dos momentos de troca, e há uma liberação da necessidade de correspondência entre as coisas trocadas, com o qual se cria a possibilidade do alargamento do mercado, ou seja, aumentam as probabilidades de mercado. E deste modo, as atividades econômicas se emancipam da situação de momento (conjuntura atual), e desde então pode-se especular sobre as futuras posições do mercado, fato que se consegue estimando em dinheiro, mediante o oportuno cálculo, tanto as probabilidades de venda como as de compra. Esta função do dinheiro, que permite levar uma contabilidade e dispor de um denominador comum por meio do qual podem se referir todos os bens, reveste-se da maior e fundamental importância. Pois, somente assim nos é oferecido uma premissa para a racionalidade calculatória da atividade econômica, somente assim há uma contabilidade (Weber, 1964: 7).

Seguindo nesse raciocínio e considerado desde o ponto de vista da evolução histórica, o dinheiro - para Weber - aparece como criador da propriedade individual: não há objeto algum com o caráter de dinheiro que por sua vez não tenha revestido o caráter de propriedade individual (Weber, 1964: 207).

A propriedade individual mais antiga consiste em objetos elaborados pelo indivíduo mesmo, utensílios e armas tratando-se do homem, e ornamentos quando se trata do homem e da mulher. Esses objetos são regidos por um direito sucessório especial, de pessoa para pessoa, e esse é um âmbito onde devemos buscar primariamente a origem do dinheiro (Weber, 1964: 207).

Em nossos dias, o dinheiro tem, antes de tudo, duas funções: de um lado serve como meio legal de pagamento, e por outro lado como meio geral de troca. Destas duas funções, a de meio legal de pagamento é a mais antiga. O dinheiro nada tem a ver com a troca; a 
aquisição desta peculiaridade se fez possível desde o momento em que uma economia sem troca conheceu também prestações econômicas que - sem se basear na troca - requeriam um meio de pagamento: tributos, presentes aos chefes, preço da noiva, dote, multas, castigos. Em suma, prestações que exigiam determinados meios de pagamento. Somente de um modo secundário se associa a estas manifestações uma forma de presente, não do súdito para seu soberano, mas do chefe a seu séquito, o salário que o senhor entrega aos seus vassalos em forma de doação, e mais tarde o pagamento do chefe dos mercenários aos seus soldados. Em Cartago, e de um modo geral no Império Persa, a cunhagem de moedas se fazia exclusivamente para intermediar pagamentos de caráter militar, e não como meio de troca (Weber, 1964: 207).

Para o autor, neste momento não cabe pensar em uma moeda uniforme como no sentido atual, mas sim em determinadas classes de objetos e bens, correspondentes a distintos tipos de prestações dentro de cada setor econômico; em que cada uma delas assume funções e pagamentos, e desta maneira coexistem moedas específicas de distintas índoles. Por exemplo, em nenhuma ocasião foi possível comprar uma mulher usando conchas como moedas, mas sim cabeças de gado, se bem que nos pequenos negócios se admitiam as conchas, porque estas permitiam a divisão em quantidades menores (Weber, 1964: 208). A esse tipo de dinheiro que nasceu das obrigações de pagamento interno, Weber o denomina dinheiro interno.

Outra das funções do dinheiro expostas pelo autor, é a de meio de entesouramento, em que o chefe querendo assegurar sua posição, devia estar em condições de manter seu séquito e de indenizá-lo com presentes em ocasiões especiais. Neste caso, o dinheiro não funciona como um meio de troca, mas simplesmente como um objeto de propriedade permanente. Quem o possui, o faz por razões de prestígio e para alimentar sua vaidade social. Para realizar essa função, o dinheiro deve possuir uma das qualidades mais importantes que hoje se exigem dele, que é sua capacidade de conservação, e não sua facilidade de transporte. Dentes de 
marfim, pedras de grandes dimensões e determinadas classes, mais tarde o ouro, prata, cobre, metais de todas as classes, serviam como dinheiro e como meio de entesouramento (Weber, 1964: 208).

Este caráter permanente da moeda se manifesta nos seguintes fatos: nas sociedades antigas a moeda se diferencia entre os sexos, não podendo possuir a mulher a mesma classe de moedas que o homem; assim a propriedade de certas peças de 'aragonita' se reserva ao homem, e as conchas de nácar são dinheiro peculiar das mulheres e são entregues como doação nupcial. Logo encontraremos uma diferenciação estamental da propriedade do dinheiro em 'moeda do chefe e 'moedas dos chefes': as conchas de determinados tamanhos somente podem ser adquiridas e possuídas pelo chefe, e somente eles podem possuí-las novamente em caso de guerra ou entregá-las como presente.

Segundo Weber, a função do dinheiro como meio geral de troca tem sua origem no comércio exterior e começou a se manifestar à base de presentes mútuos entre chefes estrangeiros (Weber, 1964: 208). O estado de paz entre os impérios pressupõe contínuos presentes entre seus soberanos e é uma troca de caráter comercial entre chefes, e nele tem sua origem o comércio entre soberanos. A interrupção de presentes significaria a guerra.

Outra de suas fontes foram as mercadorias exóticas de grande difusão pois, o comércio típico de linhagem e de tribo torna suscetível à troca determinadas mercadorias estimadas simplesmente pelo fato de não serem encontradas no mercado local. Esta moeda estrangeira assumiu uma função interior ali onde tinham que efetuar pagamentos mercantis, como taxas alfandegárias ou direitos de pedágio: o chefe garantia a segurança dos mercadores, porém teria de concordar que os comerciantes o pagassem utilizando os meios que traziam consigo. Por este procedimento a moeda estrangeira penetrou primeiramente no tráfico interior (Weber, 1964: 209). 
De acordo com Weber, nos casos mencionados acima, o dinheiro apresenta os seguintes tipos:

Dinheiro ornamental - exemplo típico são as conchas de caurí na África e territórios do Oceano Índico, até o coração da Ásia. Além das conchas, se usam - em proporções distintas como meio de pagamento ou de troca - uma série de objetos: contas de vidro, âmbar, coral, dentes de marfim, entre outros. No início, a moeda ornamental serviu para o comércio interior, e o fato de que diversas tribos utilizavam o mesmo meio de pagamento, fez com que se convertesse em meio de troca (Weber, 1964: 209).

Dinheiro utilitário - foi em princípio, moeda para o tráfico exterior de forma geral. Como meio pelo qual se expressam de um modo ou de outro, uma obrigação de pagamento, ou a valorização de outros bens, aparecem objetos de uso geral como o trigo, o gado, escravos, etc.

Dinheiro indumentário - Pode servir tanto para o comércio exterior como para o interior. Como por exemplo, peles, couro e tecidos que não costumam ser fabricados no local.

Dinheiro-signo - Em circunstâncias que todavia não tem a menor afinidade com o sistema monetário atual, uma vez introduzido o costume de considerar socialmente como objetos de propriedade, determinadas coisas, ou de efetuar por meio delas determinados pagamentos, a função monetária se associa a simples signos, que em si não representam nenhum valor. Nesta etapa o normal é que não exista somente um meio de pagamento, mas que circulem vários ao mesmo tempo, e resulta ser indispensável estabelecer equivalências entre eles (Weber, 1964: 209-210).

Para Weber, neste contexto, a base de valorações escalonadas não se constitui através de qualidades econômicas, mas sim pelo valor de uso dos bens, a importância social que a tradição lhes atribui e, por último, a necessidade de contar números redondos de fácil manejo. 
Nas sociedades mais antigas, é diferente o grau de racionalismo econômico, ou seja, no princípio encontramos o tradicionalismo que se liga ao velho, aos costumes herdados, e os transfere a outras épocas, ainda quando haja tempo, já que perderam sua significação primitiva. Somente com lentidão chega-se a superar esse estado de coisas. Por esta razão, a história econômica tem que contar também com elementos de caráter extra-econômico. E entre esses fatores estão: fatores mágicos e religiosos - a aspiração de conseguir bens de salvação; políticos - o desejo de poder e melhor posição na hierarquia social - o desejo de conseguir honras (Weber, 1964: 16).

Ao contrário, na atualidade a economia enquanto atividade lucrativa é, em princípio, economicamente autônoma, só se orienta segundo pontos de vista econômicos e é, em alto grau, racional e calculista. Porém, sempre interferem nessa racionalidade formal, fenômenos materiais e irracionais, fatos produzidos, antes de tudo, pela forma de distribuição de rendimentos que, em circunstâncias, provoca uma distribuição materialmente irracional dos bens. Por exemplo, conforme um critério material do 'melhor abastecimento possível com mercadorias'. Além de - por interesse do tipo doméstico e especulativo - que desde o ponto de vista do negócio, são de natureza irracional.

Ao observar as operações com mercadorias e com dinheiro em épocas remotas, Weber observa que nos seus primórdios, o comércio era um fenômeno inter-étnico e se dava entre pessoas de tribos diferentes, o que deu origem à uma especialização inter-étnica da produção (Weber, 1964: 173).

No caso de Weber, há convergências claras com a nossa pesquisa no momento em que é feita a distinção entre economia natural e economia monetária. Pode-se perceber que, da mesma forma que os demais autores utilizados nesta pesquisa de modo geral, há uma forte tendência - por parte de Weber - em distinguir claramente entre os instrumentais teóricos de análise das sociedades antigas e das sociedades modernas. Ou seja, Weber deixa claro que é 
preciso olhar de modo diferente para a dinâmica das economia antigas e que os conceitos usados para o estudo das economias modernas servem somente para as economia de mercado generalizado, e não para todo e qualquer tipo de economia. Concepção que está de acordo com Polanyi quando este diz que é preciso olhar diferentemente para as economias antigas.

Em relação à distinção feita por Weber entre meios de troca, meios de pagamento e dinheiro, é evidente sua proximidade com o caso andino. Ou seja, um determinado objeto pode ser utilizado como um meio de troca em determinadas situações, porém pode não ter a mesma função como meio de pagamento. No antigo Peru, a pimenta do tipo ají era utilizada como meio de troca nas esferas sociais mais baixas, no entanto não era considerada como uma forma de pagamento. Nesse momento, percebe-se novamente a proximidade de Weber com o pensamento de Polanyi, quando este último trabalha com as categorias de General Purpose Money e Special Purpose Money. Para quem, nas sociedades antigas predomina o "dinheiro" com finalidades específicas; e nas sociedades modernas, de modo geral, o dinheiro propriamente dito e tal como o entendemos hoje atua de forma genérica, ou seja, tanto pode servir como meio de troca, quanto como meio de pagamento.

Ao tratar de uma questão fundamental pertinente à nossa pesquisa, que é o grau de autonomia que a esfera econômica exerce em diferentes circunstâncias históricas, o raciocínio weberiano vai ao encontro da linha teórica de nossa pesquisa. Pois, conforme as idéias de Polanyi, enquanto nas sociedades antigas a esfera econômica se encontra encaixada nas demais esferas sociais (e isto é demonstrado de várias formas, como por exemplo - de acordo com o próprio Weber - através dos elementos extra-econômicos que influenciam e, por vezes, até direcionam as trocas), nas sociedades modernas a esfera econômica se apresenta em um grau quase que totalmente autônomo das demais.

Para Weber não há uma linha unívoca e nem um curso objetivamente progressivo no interior da História, e cabe à pesquisa histórica tratar do que é particular, daquilo que permite 
identificar na sua peculiaridade uma configuração cultural, e buscar explicações causais para essas particularidades. Segundo Cohn (1991: 12) "não é possível para Weber, encarar um período histórico como se nele estivesse já configurada a época seguinte, seja em termos de progresso ou de qualquer noção similar, que pressuponha a presença das mesmas causas operando ao longo do tempo em diferentes configurações históricas. Porém, isso não impede que Weber faça um exame comparativo entre traços de um período e traços encontrados em outros, admitindo-se a especificidade de cada um."

Assim sendo, conforme a perspectiva de Weber, não há uma seqüência causal única e abrangente na História, e toda causa apontada para um determinado fenômeno será uma entre múltiplas outras possíveis e igualmente acessíveis ao conhecimento científico.

\subsection{Karl Marx e o dinheiro universal}

Para Marx, é dinheiro a mercadoria que serve para medir o valor e, diretamente ou através de representante, de meio de circulação. Por conseguinte, ouro e prata são dinheiro, e desempenham o papel de dinheiro diretamente, quando tem de estar presente com sua materialidade metálica, como mercadoria dinheiro, portanto, e não idealmente, como sucede em sua função de medida de valor, nem através de representação por símbolos, como ocorre em sua função de meio de circulação. Desempenham o papel de dinheiro diretamente ou por meio de representante, quando configura com exclusividade o valor ou a única existência adequada do valor-de-troca das mercadorias, em oposição à existência delas como valores de uso (Marx, 1968: 144).

Pressupondo que o ouro é a mercadoria dinheiro, Marx diz que a primeira função do ouro consiste em fornecer às mercadorias o material para exprimirem o valor ou em representar os valores das mercadorias como grandezas que têm a mesma denominação, qualitativamente comparáveis. Assim, exerce a função de medida universal dos valores e só 
por meio desta função, o ouro, a mercadoria equivalente específica, se torna dinheiro (Marx, 1968: 105)

O que dá às mercadorias valor não é o dinheiro, mas sim a incorporação do trabalho humano agregado à elas. E é isso que as tornam comensuráveis e as transformam em medida universal de valor, ou seja em dinheiro. O dinheiro como medida de valor, é a forma necessária de manifestar-se a medida imanente do valor das mercadorias, o tempo trabalho (Marx, 1968: 106).

Uma das principais colocações de Marx é a de que os fatores de valor de uso e não valor de uso, são determinantes nas trocas. O processo de troca realiza a circulação social das coisas, ao transferir as mercadorias daqueles para quem são não valores de uso, para aqueles perante quem são valores de uso. E é a utilidade de uma coisa que faz dela um valor de uso (Marx, 1968: 114).

Ao tratar do porquê dos metais preciosos (ouro e prata), serem eleitos como equivalente geral, Marx afirma que esta eleição ocorre no momento em que a troca de mercadorias rompe os laços locais, e se cristaliza cada vez mais trabalho humano, em geral, no valor das mercadorias, passa a forma dinheiro a localizar-se nas mercadorias que, por natureza, se prestam a função social de equivalente universal, os metais preciosos. Sendo que, a forma adequada de manifestar-se o valor, ou seja, o dinheiro, só pode ser uma matéria cujos espécimes isolados possuam idêntica qualidade. O dinheiro deve ser divisível, mas também deve se recompor facilmente. E, por natureza, o ouro e a prata possuem essas propriedades (Marx, 1968: 99-100).

O dinheiro é para o autor apenas o reflexo que adere à uma única mercadoria, das relações existentes entre todas as mercadorias. E o preço é a designação monetária do trabalho corporificado na mercadoria. Ou seja, a troca de mercadoria por mercadoria é igual a circulação do trabalho social materializado, o que pressupõe uma divisão social do trabalho. 
O próprio curso do dinheiro, ao separar o valor real do valor nominal da moeda, a existência metálica desta de sua existência funcional, traz latente a possibilidade de o dinheiro metálico ser substituído, em sua função de moeda, por senhas feitas de outro material, por meros símbolos (Marx, 1968: 139).

Em relação ao marxismo, foi na França onde ocorreu a união entre o estudo da economia das sociedades antigas e as idéias de Karl Marx. Lá, diversos autores utilizaram-se da abordagem marxista para tentar compreender como funcionava a esfera econômica nas sociedades arcaicas. E, mais do que o Marx dos textos fragmentários, provisórios, marginais, relativos às sociedades arcaicas, que ai não são estudadas em si mesmas, cedo dominou o Marx analista em profundidade das leis de uma formação social, o capitalismo, sendo a este título mestre de um método e de um conjunto de questões fundamentais; mostrando igualmente a especificidade e a historicidade das diversas formações sociais, demonstrando assim a necessidade de descobrir para cada uma os conceitos adequados ao esclarecimento do seu funcionamento (Moniot, 1976: 68).

No que se refere à distinção entre meio de troca, meio de pagamento e dinheiro, Weber faz uma distinção como vimos, entre todos eles, enquanto Marx diferencia apenas meio de pagamento e dinheiro, sendo que o dinheiro seria algo muito mais próximo do meio de troca.

Da mesma forma que Weber, Polanyi afirma que a existência da troca não implica no uso do dinheiro, ou seja, é possível calcular em dinheiro e trocar em espécie.

Enquanto Polanyi e Weber trabalham com a idéia de diferentes tipos de dinheiro para diferente funções, Marx não trata dessa questão e concebe o dinheiro como universal, o que é natural já que este autor lida sobretudo com a sociedade capitalista em que impera a economia de mercado e onde o dinheiro é, de fato, universal. 
Weber, Mauss e Polanyi tratam cuidadosamente do caráter extra-econômico das trocas; enquanto que Marx não trabalha com essa questão. Pelo menos não explicitamente.

Weber distingue economia autônoma de economia tradicional. Idéia reforçada e enfatizada por Polanyi. Em seu texto, Marx não faz essa distinção.

Feitas algumas comparações iniciais entre os autores que servem de base para essa pesquisa, fica patente que há uma certa aproximação entre Mauss, Weber e Polanyi, enquanto que Marx estava mais preocupado em sua análise das economias modernas e capitalistas, tratando apenas marginalmente de questões relativas às economias antigas.

Portanto, em relação ao marxismo o que nossa pesquisa nega é a idéia de evolução necessária das instituições sociais. Rejeitamos, simultaneamente, a idéia de um sistema unilinear que vê o destino da humanidade através de estágios determinados: escravismo, feudalismo, capitalismo e socialismo até chegar no comunismo. Cremos que as sociedades têm certamente uma história, mas essa história não segue as leis e etapas de uma evolução obrigatória e necessária. Se fizermos uma análise majoritariamente marxista em nossa pesquisa seríamos levados a crer que devido ao aumento produtivo gerado pelo sistema redistributivo baseado em uma hierarquização social e - mesmo que minimamente - na propriedade privada, a sociedade Inca teria indicativos de classes sociais, e portanto seria précapitalista ou "semi-feudal", como pretende o arqueólogo peruano Lumbreras (1989). Ou mesmo, poderíamos cair na idéia oposta - defendida por outros autores - de que a sociedade Inca seria uma representante de um tipo primitivo de socialismo, como sugerido por Baudin (1943).

É preciso colocar que o que descartamos não é a obra de Marx em si, que sem dúvida nos trouxe enormes e incontáveis contribuições, mas sim os desvios marxistas que, com abordagens simplistas, muitas vezes acarretaram análises distorcidas das sociedades antigas. 
A teoria substantivista dá a impressão de querer distanciar-se a todo custo da teoria marxista - principalmente no que toca o papel dos fatores econômicos e das regras de passagem de uma instituição dominante a outra - para não chegar às mesmas conclusões políticas sobre o caráter efêmero da existência do modo de produção capitalista. Démonio (1976), questiona se esta postura não seria uma conseqüência da situação política da América do norte maccarthista, ambiente em que trabalhou Polanyi. Seguindo este raciocínio, Démonio (1976: 57), afirma que é precisamente na ausência de qualquer explicação quanto ao papel da mudança da economia na História que deve se ver o limite da aproximação substantivista. 


\section{CAPÍTULO 3}

\section{OS CRONISTAS E SEU TEMPO}

"Foram nossas sociedades ocidentais

que, muito recentemente, fizeram

do homem um animal econômico."

Marcel Mauss

Enquanto no início do XVI na área andina, Huascar e Atahualpa disputavam entre si o poder do Império Inca, devido ao vácuo deixado após a morte de Hayna Capac; do outro lado do Atlântico os povos ibéricos davam início ao movimento expansionista que resultaria - em última instância - na colonização, invasão e/ou destruição da América.

Peru e Espanha viviam situações tão distintas há apenas poucas décadas do encontro desses dois universos diferentes. Encontro que marcaria para sempre o destino do Quarto Mundo, Novo Mundo ou do que hoje conhecemos por América espanhola.

A Europa do século XV era uma sociedade que ainda sofria perturbações econômicas e sociais causadas pela Peste Negra. Era pequena a oferta de mão de obra; as rendas da aristocracia haviam caído; os monarcas e os nobres competiam por poder e recursos. Era também uma sociedade que se sentia ameaçada em suas fronteiras orientais pela presença hostil do Islã e pelo avanço dos turcos otomanos. Era uma sociedade intranqüila e relativamente móvel, ao mesmo tempo inquisitiva e aquisitiva - inquisitiva sobre o mundo que estava além de seus horizontes imediatos e aquisitiva em seu desejo de objetos de luxo e iguarias exóticas e de ouro que permitisse comprar esses artigos do Oriente com quem ela tinha um saldo comercial permanentemente desfavorável. Havia, além disso, a questão do fortalecimento político das Coroas peninsulares, fim da Reconquista contra os mouros e presunção de superioridade religiosa e moral (Elliott, 1998: 138-139; Giucci, 1992: 11). 
Após diversas e anteriores viagens da Espanha com destino à América, Francisco Pizarro e seus companheiros chegaram ao Peru em 1532. Antes disso, outros espanhóis já haviam desembarcado na América Central e suas experiências por aquelas terras já indicavam quais eram as aspirações e objetivos que os homens "brancos como giz e montados em seus veados" (apud: Elliott, 1998: 197) desejavam na América do Sul, mais particularmente na região andina .

A expansão dos espanhóis pelo continente americano expressou a vontade de uma constelação de indivíduos que, convencidos de sua superioridade cultural e religiosa, trilharam terras estranhas a serviço da Coroa de Castela e da cristandade, ávidos por poder, ganhos e benefícios econômicos (Giucci, 1992: 12).

Tudo indica que a conquista da América não foi fruto do acaso pois, as expedições necessitavam de autorização dos reis ou de seus representantes, eram comandadas por chefes que assumiam plena responsabilidade e eram controladas por contratos que delimitavam desde as áreas territoriais a serem exploradas até a duração temporal dessas explorações. Ou seja, eram muito bem planejadas e as incursões e expedições européias nos pontos geográficos assinalados pelos documentos reais eram justificadas pela consecução de objetivos específicos, como descobrir, resgatar, povoar e governar. Porém, raramente o cumprimento das metas iniciais indicadas nas cláusulas dos contratos foi o motivo central das expedições. Por trás disso estava o saque dos botins ameríndios.

Segundo Giucci, "...assim como a simples entrada nos domínios territoriais dos indígenas necessitou de uma série de normas legais que autorizassem a invasão, a apropriação do botim integrou-se a uma cosmovisão totalizadora: era concebida como a merecida recompensa ao trabalho dos servidores, ao incremento da monarquia e à difusão do cristianismo em terras infiéis" (1992: 13). 
Os espanhóis prolongaram e vislumbraram no Novo Mundo uma tradição milenar de projetos deslumbrantes que depositava tesouros imensos e inconcebíveis nos espaços inexplorados ou semi-explorados que se consideravam afastados do eixo referencial dos europeus. Assim, a vontade e o desejo de encontrar enormes quantidades de ouro e prata transformaram-se em componentes irredutíveis da conquista. Na América, o maravilhoso e a imagem das riquezas coincidiram. Porém, o fundo do maravilhoso americano foi, quase exclusivamente econômico e o imaginário do europeu estava recheado de ouro, prata e riquezas (Giucci, 1992:13).

No texto de 1534 Verdadera relación de la conquista del Perú y provincia del Cuzco llamada la Nueva Castilla, Francisco Xerez, escrivão de Francisco Pizarro escrevia:

"[...] dicen que hay dos casas hechas de oro, y las pajas de ellas, con que están cubiertas, todas hechas de oro. Con el oro que aquí se trajo del Cuzco trajeron algunas pajas hechas de oro macizo con su espigueta hecha al cabo, propria como nace en el campo. Si hubiera de contar la diversidad de las piezas de oro que se trajeron, sería cosa de nunca acabar. [...] Grandes cosas se cuentan de las riquezas de Atabaliba y su padre." (apud: Giucci, 1992:14).

Outro exemplo muito expressivo a respeito pode ser encontrado no texto Nueva Coronica y buen gobierno, escrito por Felipe Guaman Poma de Ayala em 1615:

"Dom Francisco Pizarro y Don Diego de Almagro, dos capitanes generales y los demás se juntaron trescientos y cincuenta soldados, en todo Castilla hubo grandes alborotos, era de día y de noche entre sueños, todo decía: 
Indias, Indias, oro plata, oro plata del Perú, hasta los músicos cantaban el romance: Indias, oro, plata, y se ajuntaron estos dichos soldados y mensaje del rey nuestro señor católico de España y del santo padre Papa.

De mil quinientos doce años Papa Julio dos, de su pontificado siete, emperador Maximiliano dos, de su imperio diez y siete, reina de España doña Juana, de su reinado cinco, Vascones (Vasco Núñez) de Balboa tuvo noticia de la Mar del Sur. Con esta nueva más se alborotaron la tierra que si la reina les dejara venir me parece que todo Castilla se veniera con tan rica nueva deseada, oro y plata, que la gente andaba vestida toda de oro y plata y todo el suelo lo que pisaban era todo de oro y plata macizo, que como piedra amontonaban oro $y$ plata, aun hasta ahora dura aquel deseo de oro y plata y se matan los españoles y desuellan a los pobres de los indios, y por el oro y plata quedan ya despoblado parte de este reino, los pueblos de los pobres indios, por oro y plata." (Ayala, 1996, 372/374: 281).

No entanto, ter como objetivo da conquista da América apenas o enriquecimento rápido não constituía justificativa suficiente. Era necessário fortalecer o argumento, ou seja, era preciso um fundo moral e oficial para a conquista. A resposta veio por meio do cristianismo, da conversão e salvação das almas distantes, da proteção dos pagãos sem um deus católico. 
Com a autorização papal à Castela para a conquista, a empresa das Índias foi elevada ao nível de um empreendimento sagrado de converter os pagãos à fé católica. Essa empresa missionária deu uma justificativa moral para a conquista e para a colonização dos indígenas do Novo Mundo (Elliott, 1998: 147).

Em 1648 Juan de Solórzano Pereira escreveu que os índios "porque são tão bárbaros [...] precisam de alguém que, assumindo os deveres de governá-los, defendê-los e educá-los, os reduzisse à uma vida humana, civil, social e política, de modo a poderem adquirir a capacidade de receber a fé e a religião cristã" (apud: Elliott, 1998: 300).

Porém, apesar de todas as cautelas, a obsessão dos guerreiros pelos metais preciosos levou-os a deslocar-se pela rota da imprudência, da ousadia e da crítica. E, "pressuposta a condição de representante da raça eleita por parte do viajante castelhano, os combatentes saqueavam, escravizaram e exterminaram inúmeros índios, muitas vezes sem motivos específicos ou justificáveis." (Giucci, 1992:15).

Outro fator que nos oferece dados para a compreensão da mentalidade do espanhol do século XV é o fato de que os homens que atravessaram o Atlântico eram pessoas - a maioria soldados - que pouco tinham a ganhar permanecendo na Espanha; mas na América aceitavam a dura e arriscada travessia do oceano além das diversas dificuldades em solo americano em troca de poder e dinheiro no Novo Mundo. Segundo o frade franciscano Gerónimo de Mendieta, "todos os espanhóis, mesmo o mais miserável e desafortunado, querem ser señores e viver por si sós, não como servos de alguém, mas como servos próprios" (apud: Elliott, 1998:178). E era o ouro e a prata pilhados dos índios e, mais tarde, a exploração do trabalho nativo nas minas que davam acesso aos espanhóis à fama, ao poder e às fortunas acumuladas.

Não foi por acaso que, o explorador do México, Hernán Cortez disse o que qualquer homem na mesma situação que a sua provavelmente diria: "Eu e meus companheiros 


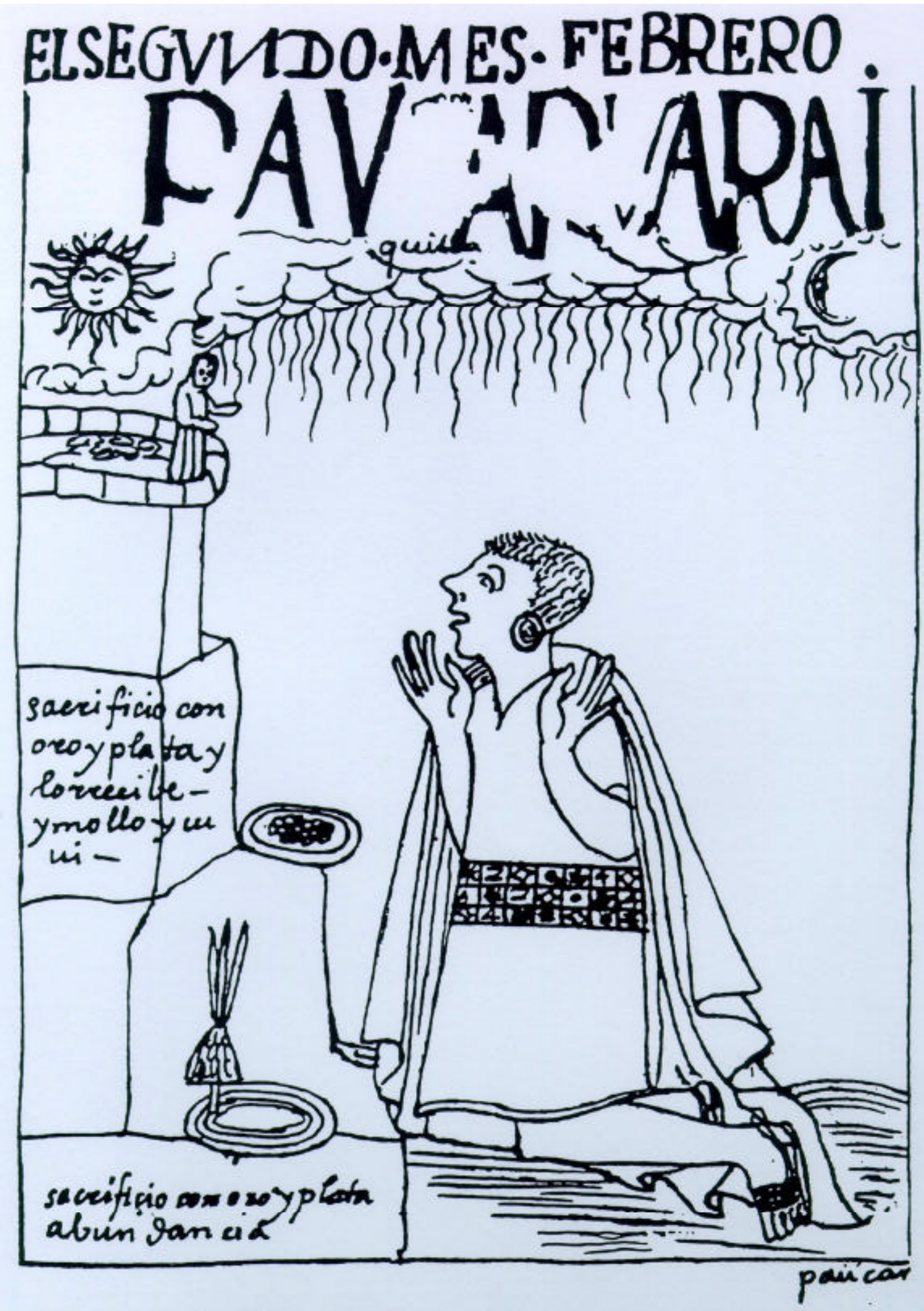

Ilustração de oferenda com ouro.

"El segundo mes, febrero / Paucar Uarai Quilla / sacrificio con oro y plata, y lo recibe, y mollo y uiui, sacrificio con oro y plata, abundancia." Fonte: Avala. F. G. P. Nueva Coronica y Buen Gobierno. Fondo de Cultura Economica, Lima, 1993: 176. 
sofremos de uma doença do coração que somente pode ser curada com ouro" (apud: Elliott, 1998: 167).

No que se refere à coroa espanhola e seus conhecimentos do que se passava em suas novas possessões, pode-se dizer que estava muito bem informada, pois uma vasta quantidade de informações escritas fluía através do Atlântico - informação que sofria atrasos de um ano ou mais, porém refletia o mais amplo leque possível de visões, desde as do grupo mais próximo ao vice-rei até as comunidades indígenas mais humildes. Questionários detalhados sobre o Peru eram enviados aos funcionários nas Índias e, à medida que retornavam à Espanha eram cuidadosamente ordenados e resumidos. Em 1571 foi instituído oficialmente o cargo de cronista das Índias, mas nessa data inúmeras descrições e narrações sobre a vida e os costumes dos índios já haviam sido geradas (Porras Barrenechea, 1986). Assim, em um contexto e com uma mentalidade muito particulares, os cronistas - de todos os níveis produziram textos de diversos tipos. Hoje é, em boa medida, por meio destes materiais que temos acesso ao antigo Peru.

\subsection{A etno-história como uma ferramenta de estudo do Império Inca}

Em 1848, com o livro Historia de la Conquista del Peru, o pesquisador norteamericano Willian Prescott realizou um dos primeiros estudos críticos das crônicas sobre a área andina, ajudando a dar início aos estudos etno-históricos no Peru que, atualmente contam com métodos de análise cada vez mais aprimorados. Porém, foi somente no século seguinte, mais especificamente na década de 80, que a etno-história ganhou um grande impulso e seus pesquisadores começaram a aperfeiçoar mais e mais os métodos de análises desses documentos. Nessa época, foi iniciado um movimento em favor da interdisciplinaridade entre a arqueologia, etnologia e a etno-história para que conjuntamente essas disciplinas pudessem compreender melhor aquelas antigas sociedades. 
A partir desse momento, no entanto, começaram a surgir alguns problemas e questionamentos relativos à metodologia na interpretação e uso desses documentos.

Segundo Trigger (1982: 9), os estudos de etno-história não se limitam em verificar se o autor do texto era mais ou menos etnocêntrico, ou se era mais ou menos amigo dos índios. Para Trigger, estudar a história dos povos não letrados depende dos documentos produzidos por pessoas externas à cultura nativa, o que é diferente de escrever a história de povos letrados que têm abundantes documentos escritos sobre suas próprias atividades. Porém, o autor ressalta que essa perspectiva que diferencia história e etno-história corre paralelamente com a distinção evolucionista entre história e pré-história, entre sociedades primitivas e civilização (Trigger, 1982:3).

Muito freqüentemente, os documentos produzidos pelos europeus tinham, em primeiro lugar, a função específica de servir à Espanha. Somente em um segundo momento, veio a tentativa de entender os nativos, estimulada pela percepção dos espanhóis de que a continuidade e eficácia da dominação dependia desta "compreensão". Portanto, quando se trata de etno-história faz-se necessária a crítica interna e externa do documento, ou seja, devem ser analisados os dados da obra em si e, simultaneamente, quais eram os interesses e a posição do autor.

Particularmente na Espanha, o gênero da crônica surgiu como um ramo dos textos épicos e, sobretudo, a crônica castelhana tinha como uma de suas características próprias uma tendência ascética e moralizadora, buscava ser simultaneamente advertência e conselho de bons governantes, espelho da verdade e exemplo de doutrina (Porras Barrenechea, 1986: 147).

Pode-se dizer que a crônica castelhana foi transportada para as Índias por vontade Real e cada vez mais foram levadas às conquistas na América pessoas que se encarregavam de fazer a descrição detalhada das terras, riquezas, usos e costumes dos habitantes nativos, até então desconhecidos para o Velho Mundo. 
Fontes de diversas pesquisas e estudos sobre as sociedades encontradas pelos espanhóis no Peru nos séculos XVI e XVII, os textos em que a etno-história se apoia podem ser divididos, basicamente, em três categorias: cronistas espanhóis enviados pela coroa como historiadores das Índias; dados administrativos oficiais e, finalmente, trabalhos realizados por autores nativos (Conrad \& Demarest 1984: 5). Obviamente, esta divisão é arbitrária e muitas outras poderiam ser feitas, porém a intenção desta divisão aqui serve apenas para nos ajudar em uma breve caracterização das fontes.

Pode-se dizer que a maioria dos cronistas era representada por conquistadores espanhóis, principalmente aqueles que chegaram cedo ao Peru, ou seja, no momento das primeiras conquistas. Muitos deles participaram das primeiras batalhas entre europeus e nativos como, por exemplo, Miguel de Estete (Pease, 1995).

Nessa primeira categoria de escritores, se encontram os cronistas oficiais do sistema colonial peruano (Polo de Ondegardo), além de alguns padres (José de Acosta e Blas Valera).

O segundo tipo de fonte é representado pelas informações oficiais que consistem em documentos preparados para os administradores civis e religiosos da colônia. Nesta categoria incluem-se os trabalhos de censo (Garci Diez de San Miguel), e também as descrições locais que funcionavam como instrumentos na conversão dos gentios e da extirpação de suas idolatrias genuínas (Franscisco D'Avila). À esta categoria, acrescenta-se ainda os dicionários de línguas nativas compilados para fins oficiais e que também representam informações muito úteis para os etno-historiadores, além dos inúmeros documentos que falam sobre disputas de terra, direitos de irrigação da água, entre muitos outros que podem ser explorados por seus mais diversos aspectos (Conrad \& Demarest, 1984: 6).

Finalmente, a terceira categoria são os textos produzidos por autores nativos, ou seja, aqueles autores que de alguma forma pertenciam e estavam, direta ou indiretamente, ligados aos Incas. Esses trabalhos e textos gerados pelos nativos foram porém, poucos e tardios. O 
texto de Felipe Guaman Poma de Ayala é de 1615, de Juan de Santa Cruz de Pachacuti Yamqui é de 1613 e o de Inca Garcilaso de La Vega de 1609. Ainda assim, é preciso considerar que nenhum deles era genuinamente nativo, pois foram convertidos ao catolicismo e tornaram-se cristãos-novos (Conrad \& Demarest, 1984: 7).

Há ainda quem faça diferenciações entre os textos produzidos por soldados que participaram ativamente das batalhas em solo peruano e os padres e jesuítas. Enquanto estes últimos aumentavam as crueldades e abusos da conquista e diminuíam a "barbárie" indígena, os textos produzidos por soldados ou a crônica soldadesca têm como característica a rudeza e o ascetismo guerreiro. O cronista-soldado simplesmente apontava os fatos e se isentava de qualquer comentário e/ou reflexão. Suas impressões sobre a paisagem, por exemplo, são rápidas e sumárias (Porras Barrenechea, 1986: 149).

Infelizmente, os povos andinos não desenvolveram nenhum tipo de escrita e as informações sobre a época pré-hispânica foram coletadas durante a época colonial e, mesmo assim, tardiamente, como mencionado acima.

As primeiras décadas da conquista do Peru foram recheadas de disputas, assassinatos políticos e brigas entre os conquistadores. Neste tipo de atmosfera violenta e instável, dificilmente alguém estaria interessado em coletar informações sobre o Império Inca. Esses motivos explicam o fato de os primeiros textos sobre o Peru começarem a ser escritos somente cerca de vinte anos após a chegada dos espanhóis em 1535 e durante este intervalo, mesmo pequeno, os sociedades nativas sofreram significativas interrupções e dados importantes foram perdidos. Um trecho da crônica de padre Blas Valera sobre este atraso, especificamente a respeito da religião dos antigos peruanos:

"La demasiada solicitud de buscar oro y plata con que entraron los españoles en el Pirú, fué parte para que ni aún a los principios ni en los años venideros se pudiese 
saber muchas cosas antiguas de la religión falsa de los piruanos; ayudaron mucho a esto las guerras civiles que por más de treinta años tuvieron los españoles entre sí unos con otros, instigados desa solicitud y codicia; y si supieron algo, no fué porque lo quisieron saber, sino porque buscando tesoros, entierros, sepulcros, donde hubiese oro y plata, y teniendo noticia de algunos, preguntaron quién y cómo lo puso allí, con todo lo demás que consecutivamente se podía saber para sacar, si habia, más tesoro." (p. 32)

Por outro lado, dentre todos os autores, mesmo os mais "cuidadosos" e "compreensivos" não chegaram a entender completamente a cultura Inca visto que todos eles carregavam consigo uma visão de mundo europeizada e na maioria das vezes tentavam entender a cultura nativa por meio de conceitos próprios da sociedade européia do século XVI e que não tinham utilidade alguma no mundo peruano (Conrad \& Demarest, 1984: 7). Um exemplo desta postura pode ser percebido quando diversos cronistas (Poma de Ayala, Santa Cruz de Pachacuti e Francisco D'Ávila), comparam a visão andina das quatro idades do mundo que corresponde a uma imagem cíclica do passado, com momentos extraídos da história bíblica e da história européia, ou seja, transportam o passado judaico-cristão para o universo incaico (Pease, 1969: 14).

As informações etno-históricas trazem consigo diversos problemas e devem sempre ser usadas com muito cuidado. Sua interpretação requer constantes comparações com outros tipos de evidências, como a arqueológica. Além disso, quando se trata de etno-história é necessário a crítica interna e externa do documento, ou seja, devem ser analisados os dados da obra em si, mas também e - simultaneamente - os interesses, a época e a posição do autor. 


\subsection{Os cronistas do Peru nos séculos XVI e XVII}

Como mencionado anteriormente, os autores que no século XVI e XVII que escreveram suas impressões e experiências no Peru não podem ser desligados do contexto e mentalidade de seu tempo. Cada um dos autores utilizados nessa pesquisa tinha suas próprias características, porém, de uma forma mais geral, todos eles - uns mais e outros menos - demonstraram que as atividades dos espanhóis em terras peruanas não eram essencialmente benevolentes e que o "estudo" daquelas culturas tinha como objetivo maior o ganho econômico. No caso dos missionários católicos, o objetivo era, principalmente, a conversão dos gentios.

Ao iniciarmos a leitura das fontes, pouco a pouco todos esses aspectos e especificidades dos cronistas foram se revelando.

\subsection{Acosta, Fray José de}

José de Acosta se enquadra na categoria de escritores cultos de seu tempo. Possuidor de ampla formação humanista, se dedicou às tarefas de evangelização, docência, assessoria administrativa colonial e, além disso, Acosta destacou-se particularmente no III Concílio Colonial de 1583 (Pease, 1995: 40).

Seu livro História Natural y Moral de las Indias publicado em Sevilha no ano de 1590 tornou-se - posteriormente - uma das obras históricas mais aproveitadas e lidas por historiadores (O'Gorman, 1995: XII). O autor foi um defensor da Contra-Reforma espanhola empenhado - como tantos contemporâneos seus - em admitir as novas tendências da igreja, até onde a fé religiosa e a imagem do mundo fundada sob seus dogmas, permitia. (O'Gorman, 1995: XXVI). 
Fundamentalmente, o pensamento de Acosta baseava-se no aristotelismo, porém sem exagerada servidão de forma que a experiência e observação pessoais do autor encontraram em Historia Natural y Moral de las Índias, um lugar propício para divulgação de suas posições particulares. $\mathrm{O}$ ecletismo de Acosta lhe permitiu manter-se à margem do imperialismo intelectual, da autoridade das Sagradas Letras e dos padres da igreja, que se exercia em todos os campos da cultura (O'Gorman, 1995: XXIV).

Se por um lado o padre Acosta tinha uma grande dose de tradicionalismo e conservadorismo, representados por seu desconhecimento da revolução intelectual e científica sobre as idéias cosmográficas (o sistema copernicano), por outro lado, o autor compreendeu muito bem os múltiplos problemas para a cultura européia com o surgimento da América e a existência dos habitantes indígenas (O'Gorman, 1995: XXV).

Seu livro Historia Natural y Moral de las Índias, trata de dois aspectos: a natureza e a história, o mundo físico e biológico e o mundo humano e moral. Seu texto contém sete capítulos, sendo os 4 primeiros sobre a natureza e os 3 restantes sobre história (O'Gorman, 1995: XXV).

Acosta tinha uma concepção providencialista da história, segundo a qual, cedo ou tarde, todos os povos da terra teriam conhecimento do evangelho e poderiam se beneficiar dos sacramentos da igreja católica. E foi no entanto, sem se descuidar da leitura atenta dos textos impressos de sua época, escritos por outros cronistas.

O livro do padre Acosta se justifica pela necessidade que existia em seu tempo em explicar sistematicamente como a América se encaixaria no seio da cultura ocidental, dentro de uma concepção de mundo européia e pré-estabelecida (O'Gorman, 1995: LIII).

Acosta aproximou-se de alguns fenômenos da vida natural com curiosidade científica mais moderna do que muitos contemporâneos seus. Administrou de forma distinta as 
informações orais que recebeu, com esta lógica e raciocínio que o padre Acosta situou os índios americanos.

Dentro das naturais limitações de sua época, Acosta mostrou uma atitude mais próxima da compreensão e do equilíbrio no que se refere aos índios, evitando generalizações precipitadas e fazendo distinções entre eles.

\section{4. Ávila, Francisco de}

Nasceu em Cuzco no ano de 1573 e formou-se na Universidade de San Marcos em Lima. Dioses y Hombres de Huarochiri era o único texto em quechua popular e conhecido nos séculos XVI e XVII, além de ser um dos únicos textos que oferece um quadro completo e coerente das mitologias, dos ritos e da sociedade da província de Huarochiri, no Peru préhispânico.

O estilo do texto é predominantemente oral o que nos leva a pensar que, muito provavelmente, a narração foi ditada por mais de um informante (Arguedas, 1966:10).

Seu texto faz parte da missão de colher o máximo de informações possíveis sobre os ritos e idolatrias da região para que - posteriormente - fosse possível a extirpação das crenças indígenas em troca da catequização européia. Porém, vinte anos antes de Ávila, outros sacerdotes já haviam passado pela região e percebido que por ali havia cerca de trinta mil almas sem sacerdotes (Arguedas, 1966: 219).

Dessa forma, voltado especialmente para a vida religiosa pagã dos nativos, o texto de Ávila não dá em nenhum momento atenção à vida econômica dos índios porém, em suas diversas descrições e relatos a respeito dos santuários e ritos locais, o autor não deixa de mencionar objetos e contextos muito interessantes para a nossa pesquisa. 


\subsection{Betanzos, Juan de}

Betanzos foi um dos poucos cronistas que conheceu de muito perto o runa simi ou quechua, pois foi casado com Cusi Rimay Ocllo - ou Angelina, para os espanhóis - uma mulher descendente da nobreza Inca que lhe proporcionou acesso direto à tradição oral andina conservada pela elite dirigente cuzquenha, da mesma forma que o ajudou a aprimomar e compreender melhor a língua usada em tempos incaicos.

Betanzos, dentro dos limites de compreensão de sua época, soube dar a devida importância à reciprocidade andina, mesmo não sabendo explicar detalhadamente essa instituição, destacou sua importância e significado (Pease, 1995).

\subsection{Blas Valera}

Nasceu em Chachapoyas em 1545, viajou para a Espanha em 1590 e lá faleceu em 1596. O padre Blas Valera falava fluentemente o runa simi e tinha grande conhecimento sobre os quipus.

Além de Relaciones Antiguas de los Naturales del Perú, escreveu também Historia de los Incas, porém este texto foi perdido e há a hipótese de que tenha sido destruído no incêndio e saque de Cadiz pelos ingleses.

\subsection{Diez de San Miguel, Garci}

O texto de Diez de San Miguel faz parte dos documentos regionais que têm a vantagem de descrever detalhadamente os grupos étnicos. O autor integra o grupo daqueles que não tinham pretensões literárias, o grupo dos oficiais reais e burocratas enviados pelas autoridades coloniais para relatar e descrever sobre determinadas situações sociais e humanas da área andina. 
O texto estudado aqui faz parte da série de documentos que foram confeccionados antes das reformas de Francisco de Toledo e, principalmente, antes que se extinguissem as gerações de homens andinos que conheceram intimamente e puderam participar da vida incaica.

Para a confecção de Visita hecha a província de Chucuito em 1534, o autor entrevistou os líderes locais, os europeus estabelecidos na região, mercadores e também funcionários. Ao longo de sua visita, recolheu depoimentos sobre diversos aspectos, tais como os recursos da população local para o pagamento de tributos reais, a eficácia da catequização européia, além da prática da medicina e a conveniência de oferecer aos naturais vinho (chicha) a crédito (Murra, 1964: 421).

Não se sabe como, porém os Lupaca - população descrita por Garci Diez no texto em questão - tinham acesso a dinheiro efetivo para pagar seus tributos aos espanhóis. Este fato chama a atenção visto que o peso e a prata eram escassos tanto para os europeus como para os nativos. No entanto, há evidências de que a fonte de riqueza e dinheiro dos Lupaca vinha das grandes quantidades de camelídeos que possuíam (Murra, 1964: 422-423).

Os dados históricos pós-conquista têm grande valor, porém o autor concentra seus estudos - fundamentalmente - nas civilizações e acontecimentos anteriores à chegada e conquista dos espanhóis. Segundo Murra (1964: 425), no que diz respeito à região do Collasuyu (sul do império), o informe de Garci Diez é a fonte mais antiga e detalhada do século XVI (Murra, As etnias de que trata o autor, foram leais ao Inca e a ele prestavam serviços como todas as outras unidades domésticas sob o poder de Tahuantinsuyu.

Como é conhecido, no Estado Inca não havia tributos em espécie, exceto alguns artigos como, por exemplo, pluma e pescado. Os ingressos do Estado consistiam do acesso intenso da energia em forma de trabalho dos mitayos. Com este texto de Garci Diez podemos ter acesso bastante detalhado de como funcionava esse sistema (Murra, 1964: 430). 
O texto reforça a idéia de que as prestações de trabalho para exploração de recursos deveriam ser solicitadas formalmente e sempre eram entendidas dentro do sistema da reciprocidade.

\subsection{Estete, Miguel de}

Chegou em terras peruanas juntamente com Francisco Pizarro e foi testemunha ocular do episódio do seqüestro de Atahualpa em Cajamarca, fato que lhe possibilitou escrever um dos mais interessantes textos a respeito deste acontecimento.

\subsection{Guaman Poma de Ayala, Felipe}

Ayala era descendente de uma antiga dinastia de senhores locais andamarcas, na atual província de Lucanas no Departamento de Ayacucho. Em uma correspondência de 14 de fevereiro de 1615 enviada ao rei da Espanha Ayala dizia ter 80 anos e portanto deveria ter nascido em 1535. No entanto sua data de nascimento ainda hoje é motivo de polêmica entre seus biógrafos. Porém, acreditamos que neste caso, o mais importante é o fato de que o autor nasceu próximo à chegada dos espanhóis ao Peru e que "...qualquer variação não altera nem sua possibilidade de obter informações sobre o passado andino, nem a impressão obtida por meio do processo de colonização e conquista" (Pease, 1969: 10).

Durante muito tempo o autor esteve ligado à administração colonial e desempenhou a função de Tenente do Corregedor da zona de Lucanas. Trabalhou também como ajudante de vários visitadores e foi intérprete o que lhe permitiu mover-se por diversas e distintas regiões andinas. Ou seja, Ayala conheceu de muito perto as condições em que foi implantado o regime vicerreinal e visivelmente utilizou documentos administrativos na confecção de Nueva Coronica, inclusive para trancrevê-los. 
Nueva Coronica y Buen Gobierno foi destinado à Felipe III e escrito - provavelmente durante o período de 1585 a 1615 . O texto é dividido em duas partes sendo que a primeira discorre sobre o passado andino e principalmente sobre os Incas. Já a Segunda parte trata dos acontecimentos posteriores à conquista e relata a situação do indígena frente a conquista espanhola. Segundo Pease, é neste momento em que o texto se aproxima muito da "visão dos vencidos" (Pease, 1969: 13).

Se por um lado Ayala é considerado por muitos pesquisadores como um cronista toledano, ou seja, aqueles que difamavam os Incas para justificarem a conquista; por outro lado - mesmo após ter se convertido ao catolicismo - o autor faz inúmeras críticas à evangelização quando se refere aos doutrinários católicos e aos curas locais. "É conhecido que as autoridades eclesiásticas da colônia e os superiores da maioria das ordens religiosas aceitavam no sacerdócio um grande número de aventureiros que não cumpriam os requisitos mínimos e que agravavam a situação indígena..." (Pease, 1969: 12). Essas práticas e suas consequiências foram os principais motivos das críticas de Ayala e delas salvam-se somente os jesuítas para quem o autor destinava muitos elogios (Pease, 1969: 12). Uma das preocupações centrais de sua crônica foi a denúncia dos maltratos aos nativos, as explorações perpetuadas pelos espanhóis, principalmente contra as mulheres.

Por meio de toda a experiência adquirida ao lado dos europeus, Ayala soube perfeitamente dominar e se apropriar dos códigos lingüísticos espanhóis e deles fazer uso para rebaixar os Incas para justificar a conquista e - ao mesmo tempo - delatar os abusos e explorações contra seus compatriotas nativos. Como vemos, parece-nos que o autor faz simultaneamente dois discursos e esta idéia é reforçada por meio de seus desenhos em contraposição com a parte escrita da crônica pois, para alguns pesquisadores os desenhos não servem apenas como simples ilustrações ao texto mas, ao contrário são um contraponto 
essencial. Ou seja, enquanto o texto faz apologias aos espanhóis, os desenhos contém elementos que elevam os nativos.

Segundo Wachtel (1973: 226 e 228), "Guaman Poma percebe o mundo colonial através da visão do sistema espaço-temporal indígena e sua ideologia legitima o retorno a uma ordem primordial. Os aportes da cultura ocidental estão subordinados ao mecanismo de uma lógica preexistente, que sobrevive aos transtornos da conquista; sem dúvida, os novos elementos modificam o conteúdo do sistema, mas não se submetem aos seus princípios de classificação que os ordenam, fazendo uso das transformações internas. Neste sentido, a reconstrução de Ayala, longe de ser um caos mental como querem alguns, representa uma síntese elaborada segundo a lógica rigorosa do pensamento indígena. Este não funciona em estado puro, mas aceita uma certa dose de domesticação, mas a absorve sem deixar de ser ele mesmo, conduzido ao limite extremo de suas possibilidades. Ayala queria transformar a sociedade em que vivia, restaurá-la dentro de sua ordem; queria, em resumo, abolir a dominação colonial e sua utopia conduz à rebelião."

\subsection{Polo de Ondegardo, Juan}

Natural de Valladolid (Espanha), Polo de Ondegardo foi um fecundo escritor cuja atividade em terras peruanas, diferentemente do que acontecia com a maioria dos cronistas, não se limitou ao estudo das antigüidades peruanas, visto que tratou também de temas jurídicos e políticos de sua época. De 1558 até 1560 o autor ocupou o cargo de corregedor de Cuzco, tempo em que teve a oportunidade de conhecer melhor a cultura Inca e teve também a oportunidade de encontrar corpos mumificados Incas, adoratórios e huacas ao longo dos quatro caminhos de Tahuantinsuyu. Seu posto dentro do sistema colonial the oferecia uma privilegiada posição quanto ao pronunciamento de situações e fatos concretos (Alonso, 1990: 20). Isto permitiu-lhe dedicar muitos anos de sua vida ao estudo da vida incaica, além de seus 
auxílios prestados às ordens religiosas peruanas e também da cópia de seus escritos. Utilizava, como sistema de informação, enquetes que preparava com antecedência e com meticulosidade quase científica (Alonso, 1990: 24-25).

Parece existir nas obras de Polo uma clara finalidade: a melhoria das instituições coloniais partindo do conhecimento que o mundo indígena lhe proporcionava (Alonso, 1990: $19-20)$

\subsection{Vaca de Castro, Cristóbal}

Nasceu por volta de 1492 perto de Maiorca, Espanha porém, os primeiros anos de sua vida são mal conhecidos. Em 1537, foi membro do tribunal de Valladolid quando, em virtude de suas competências jurídicas, foi enviado para o conselho das Índias no Peru, a fim de controlar e de diminuir os poderes de Pizarro. Em 1541, desembarcou em Nombre de Dios, atravessou o istmo e embarcou ao porto de Lima.

Como governador do Peru, pacificou o país, encorajou o casamento de mulheres indígenas da elite incaica com os governadores espanhóis, organizou inspeções nas vilas indígenas e dividiu o país em bispados.

No entanto, por ter sido suspeito por corrupção, sua prisão foi decretada. Com a ajuda de um sobrinho, porém, conseguiu fugir e chegar até o Panamá, e de lá até a Espanha através de Lisboa. Quando se apresentou à corte de Valladolid, em junho de 1545, foi preso e encarcerado em Arévalo, e depois em Simancas, local onde permaneceu por muito anos. Foi reabilitado em 1556 e faleceu em 1562 (Bernand, C.; Gruzinski, S., 1997: 629). 


\section{CAPÍTULO 4}

\section{ANÁliSe do CATÁlogo: O PAPEL DO "DINHEIRO PRIMITIVO" NA ECONOMIA INCA}

A partir da análise dos dados procedentes do catálogo e por meio das tabelas realizadas a partir dele, podem ser feitas dois tipos de leitura na intenção de compreendermos um pouco mais sobre o papel do "dinheiro primitivo" na economia Inca. Em primeiro lugar, por meio dos sete contextos estabelecidos (meio de troca, meio de pagamento, medida de valor, entesouramento, mágico-religioso, reciprocidade e prestígio) Em segundo lugar, por meio de cada um dos objetos estudados nesta pesquisa (coca, ají, conchas, hachitas de cobre, ouro, prata e plumas)

Partindo da análise contextual do catálogo, pode-se observar que entre todos os contextos estabelecidos como uma forma de análise do "dinheiro primitivo" na sociedade e economia Inca, o contexto mágico-religioso foi o que demonstrou maior força e intensidade em número de citações (total de 140). Isto significa que, na maioria das vezes em que foram citados, todos os objetos estudados participavam de trocas com a esfera religiosa, seja por meio de oferendas aos deuses, aos mortos ou em sacrifícios.

Neste caso particular do contexto mágico-religioso, o ouro representou o item mais citado (45 vezes), seguido - respectivamente - da prata (37 vezes) e da coca (31 vezes). Estes números evidenciam que o caráter extra-econômico do "dinheiro primitivo" e suas estreitas ligações entre economia e religião no mundo andino se fazem presentes nas crônicas. Esse dado extraído do catálogo é um dos mais interessantes, visto que demonstra claramente o caráter multifacetado do "dinheiro primitivo" no antigo Peru. Ou seja, esses objetos acionavam diferentes esferas sociais. 
Logo após o contexto mágico-religioso, foi o contexto de prestígio que apareceu com maior quantidade de citações (63 vezes). Neste contexto, todos os objetos foram mencionados, sendo que o ouro ( 23 vezes) e a prata ( 22 vezes) apareceram mais que os outros itens.

No caso do contexto de prestígio, o número de citações de conchas, plumas, cobre, ouro e prata, confirmam a hipótese de que o acesso a esses bens era limitado e altamente controlado pois, esse contexto é definido como objetos que dão ao seu portador prestígio, status social e político e, sobretudo, indicam hierarquia social e política.

Depois dos contextos mágico-religioso (140 citações) e de prestígio (63 citações), foi o contexto de meio de pagamento que surgiu com maior número de citações (38 vezes). Juntamente com os dois primeiros contextos citados acima, formam o conjunto dos casos em que todos os objetos receberam pelo menos uma citação. Isto é, com maior ou menor intensidade todos os itens eram utilizados como uma forma de pagar algo a alguém (pessoa, grupo ou Estado). Neste caso, da mesma maneira que no contexto meio de troca, a coca aparece novamente com maior número de citações sobre os demais objetos.

No entanto, no caso do contexto de meio de pagamento, sabemos que não havia tributo em espécie no império Inca e que o tributo era pago em forma de tempo de trabalho despendido, isto é, a mita. Porém, os cronistas espanhóis provavelmente por desconhecerem em detalhes como funcionava o sistema redistributivo incaico, não faziam essa distinção e, talvez por isto, mencionem freqüentemente a tributação em espécie desses bens.

Por outro lado, deve ser considerado o fato de que os artigos mais importantes e de maior valor no império Inca eram enviados diretamente para Cuzco, ao contrário dos bens mais comuns que poderiam ficar em depósitos locais. Fato que demonstra a maior atenção e interesse por parte do Estado por esses artigos especiais e mais valorizados em relação aosoutros objetos. O trecho abaixo, extraído do catálogo e de autoria de José de Acosta (ver 
ficha $\mathrm{N}^{\circ}$ 7), demonstra melhor como, no caso da coca, o Estado exercia o controle direto e intenso:

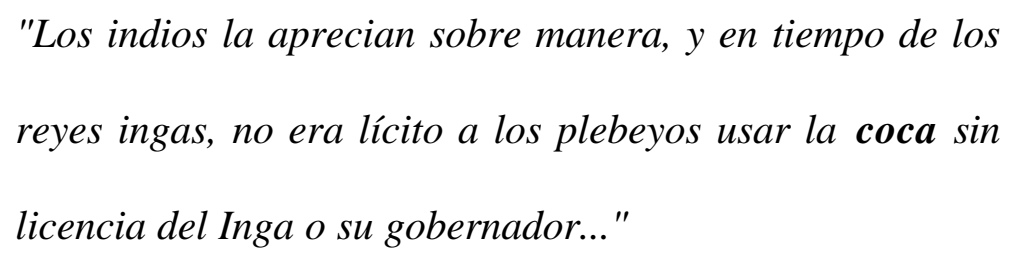

No contexto meio de troca somente a coca, o ají, o cobre e a prata mereceram 12 citações no total. Destes itens, a folha de coca foi o que mais apareceu ( 7 vezes), desempenhando a função de meio de troca, ou seja, participava diretamente no sistema de intercâmbio como uma forma de obtenção de produtos. Os demais objetos citados neste contexto (ají, cobre e prata), também desempenhavam esta função porém, de forma mais restrita e sem a mesma intensidade observada no caso específico da coca.

Durante o processo de execução do catálogo, o contexto da reciprocidade era acusado quando determinado objeto atuava nas trocas não relacionadas a esfera de subsistência, mas sim ao prestígio das pessoas e grupo envolvidos. E também quando participava das trocas de presentes entre chefes.

No entanto, sabemos que a reciprocidade - em muitos casos - poderia estar diretamente relacionada com o controle político. Os dados procedentes do catálogo parecem reforçar essa idéia como, por exemplo, nos seguintes trechos escritos por Betanzos em seu texto, Suma y narración de los Incas:

"...y guardando en todo y por todos los mandamientos y cosas ordenadas por su padre ansi mismo entendía en enviar muchas cosas y dádivas a los señores caciques naturales de toda la tierra enviando a unos ropa preciada y a otros mujeres de la nación del Cuzco en quien viniesen sus descendientes y sus sucesores y a otros vasos y joyas 
de oro y plata según que a él mejor le parescía todo lo cual hacía Topa Ynga Yupangue por tenerlos y conservarlos en su amistad porque no se le rebelasen y le inquietasen..." (p. 139)

"...Guayna Capac juntamente con los gobernadores entendieron en mirar las cosas de su ciudad y república della todo lo cual hecho y acabado de proveer ansi por los visitadores que a las provincias fueron como por Guayna Capac y los gobernadores ya que fueron vueltos los señores visitadores Guayna Capac y los gobernadores ordenaron de enviar grandes dones y dádivas de ropa ovejas vasos de oro y plata y mujeres de la nación del Cuzco a todos los caciques señores de toda la tierra y como ansi lo ordenasen luego lo pusieron por obra y enviaron lo cual ordenaron e hicieron por conservar sus vasallos y súbditos en su amistad y amor y tenerlos siempre en contentamiento lo cual siempre hicieron los gobernadores por tenerlos quietos y pacíficos todo el tiempo que ellos gobernasen..." (p. 142)

No contexto entesouramento não houve nenhuma citação em nenhum dos objetos estudados. No entanto, no caso específico do cobre, diversas escavações arqueológicas evidenciam a sua utilização como entesouramento. Como, por exemplo, as 13 mil hachitas encontradas em um único enterramento ou os 20 mil exemplares achados em sepultamentos de nobres, ambos no norte do Peru. Como sabemos, esses dados só foram evidenciados no 
século passado por meio de escavações arqueológicas, ou seja, provavelmente os espanhóis tiveram pouco contato com os enterramentos contendo esse tipo de material. Talvez esse dado possa explicar o pouco número de menções sobre o cobre nas crônicas.

Além disso, os tambos - depósitos estatais ao longo de todo o império - podem ser compreendidos também como uma forma de entesouramento, já que o Estado se valia desse recurso para acumular e retirar de circulação mercadorias de todos os tipos (incluindo as estudadas aqui), como uma forma de tornar estável o seu poder e de controlar o vasto território imperial. O episódio do resgate do seqüestro de Atahualpa pelos espanhóis em 1532 em Cajamarca (norte do Peru), ilustra muito bem a importância e grandiosidade desses depósitos. Pizarro e seus homens seqüestraram Atahualpa - irmão de Huascar e filho de Hayna Capac - e em troca pediram ouro. Rapidamente, enormes quantidades de ouro e outras mercadorias valiosas começaram a chegar na cidade, vindas em sua maioria, dos depósitos estatais (Bernand, C.; Gruzinski, S. 1997: 516).

No que se refere ao contexto de medida de valor, este recebeu poucas citações e somente de alguns objetos (coca, cobre, ouro e prata). O total de menções referentes ao contexto de medida de valor totaliza 5 e é o contexto com menor número de citações, só ficando atrás do contexto de entesouramento que não recebeu nenhuma citação. A coca, mais uma vez, com mais intensidade em relação aos outros itens o que fortalece a tese de que o seu uso era amplo e intenso na área andina.

Observando os dados da tabela 1 do ponto de vista dos objetos, o ouro e a prata foram os dois itens que mereceram o maior número de citações, respectivamente, com 77 e 70 menções. Porém, cuidado especial deve ser dado quando se trata desses metais, pois como é exaustivamente conhecido, a obsessão espanhola pelo ouro e pela prata faz com que esses 


\section{DEPOCITODEILIVGA}

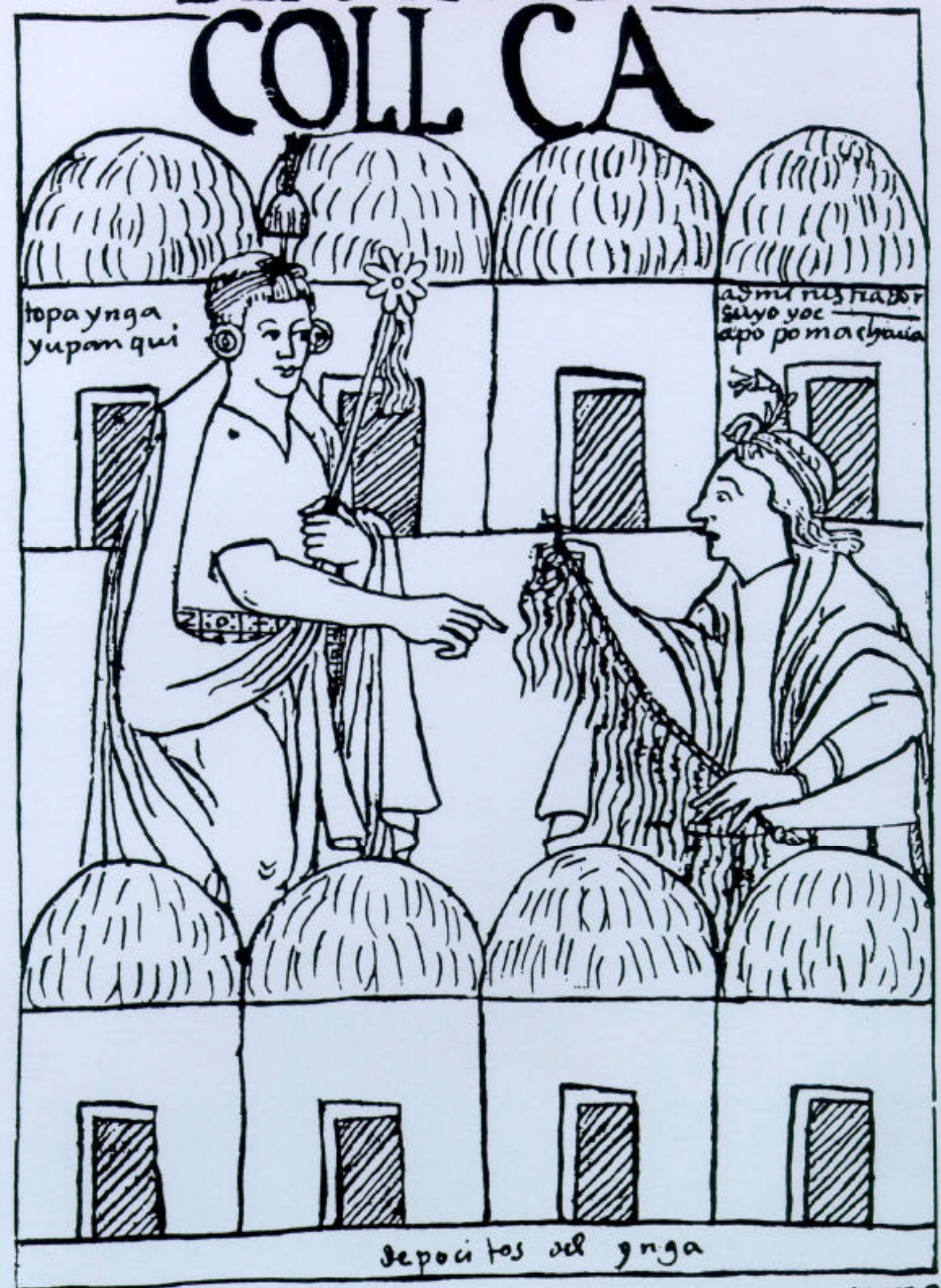

Depósitos incaicos.

"Depósito del Inga / Collca / Topa Inga Yupanqui / Depósitos del Inga."

Fonte: Ayala, F.G.P. Nueva Coronica y Buen Gobierno.

Fondo de Cultura Economica, Lima, 1993: 253. 
dois itens apareçam nas crônicas escritas pelos espanhóis de forma expressiva e com maior presença em relação aos demais objetos.

Obviamente, ouro e prata tinham muita importância e significado ao longo da antigüidade andina e também para o império Inca, no entanto, nada comparado ao desejo intenso e insaciável dos conquistadores espanhóis por esses metais. Se por um lado, esses dois artigos em especial foram exaltados e mereceram maior atenção nas crônicas, por outro lado, pode-se supor que exatamente o contrário aconteceu com os demais objetos que podem ter tido sua importância minimizada graças a já mencionada obsessão pelo ouro e pela prata À essa questão pode-se acrescentar a falta de compreensão por parte dos europeus em relação ao mundo andino e à noção de valor que encontraram entre os nativos da América do Sul, mais especificamente entre os Incas. A ausência de entendimento e de conhecimento dos povos andinos por parte dos conquistadores, adicionado ao desejo por metais, não permitiu que os europeus percebessem com maior clareza o valor (econômico, simbólico e ideológico) dos demais objetos no interior da economia e sociedade Inca.

Em terceiro lugar, após o ouro e a prata, a coca surge com 64 citações em todos os sete contextos estabelecidos, exceto o de entesouramento. Este objeto é mais citado no contexto mágico-religioso (31 menções), seguido do contexto de meio de pagamento (13 menções).

Considerando que o ouro e a prata têm maior expressividade por motivos já mencionados, a coca foi o item que mais chamou a atenção de alguns cronistas, provavelmente devido à sua grande circulação na área andina e nas mais diversas esferas e níveis sociais e também pelo grande uso que os nativos faziam dela, mascando, oferecendo aos deuses, em rituais e nas trocas. 
Efetivamente, sabe-se por meio da bibliografia, sobre a importância das folhas de coca em todo o âmbito andino e em todas as esferas e hierarquias sociais, suas propriedades medicinais e sua estreita relação com a esfera religiosa.

Parece que tamanha importância chamou também à atenção dos cronistas dos séculos XV e XVI que mesmo por meio de uma noção de valor européia e etnocêntrica, não cansam de citar e descrever sua grande circulação e significado e, algumas vezes, dão à coca o caráter de dinheiro:

"...A ellos les sabe bien y dicen les hace provecho, y dan su dinero de buena gana por ella, e con ella rescatan como si fuese moneda, cuanto quierem."

(Acosta, Libro Cuarto, Capítulo 22: 181-182).

A coca, como pode ser visto na bibliografia e reforçado pelo catálogo, tinha uma circulação bastante ampla tanto no que se refere às hierarquias sociais, quanto às mais diferentes áreas geográficas. Além de que, sua importância e valor não se limitaram aos tempos incaicos, mas entenderam-se a períodos anteriores. A coca talvez tenha sido, entre todos os objetos estudados, aquele que mais se destacou em intensidade, amplitude de circulação e atuação na área andina.

Como pode ser visto nos trechos abaixo, os cestos de coca representavam medidas de valor e podem ter servido como um equivalente de preços em determinadas situações:

"En tiempo de fiesta y pascua les repartían en la plaza pública unos cestos grandísimos de coca llamados auan cari, y unos carneros grandísimos de la plaza, se los llevaban unos cayua con el hato, otros le derribaba los carneros; esta fiesta el Inga y los demás señores se reían y 
se entretenían en esta fiesta en las ciudades." (Ayala, 337

/339: 254).

"Vale un cesto de coca en el Cuzco, de dos pesos y seis tomines, y a cinco pesos ensayados; y es el género sobre que se hacen cuasi todas las baratas o mohatras, porque es mercadería de que hay gran expedición."

(Acosta, Libro Cuarto, Capítulo 22: 181).

A bibliografia está de acordo com a idéia de que a coca efetivamente tinha funções de medida de valor: "o Runcu, medida de capacidade, era utilizada sobretudo para medir a coca e o ají e deve ter sido empregado como unidade nos inventários dos depósitos reais." (Rostworowsky, 1958: 107). A autora acrescenta que no texto Relaciones Geográficas de Indias, há a menção de cestos de coca cestos que serviam como medida de valor e como referência para a troca com outros artigos (Rostworowsky, 1958: 107).

Pesquisas arqueológicas recentes realizadas em Arequipa (litoral sul do Peru), têm demonstrado - por meio de análises físicas e químicas de restos encontrados em múmias - que a coca era utilizada em sacrifícios humanos para dopar as vítimas que eram sacrificadas em favor dos deuses andinos ${ }^{10}$.

Como visto, a coca, tinha ampla circulação em todos os níveis sociais e simultaneamente - alta expressividade em todos os contextos estabelecidos nesta pesquisa, como pode ser observado na tabela geral. Por esses motivos, a coca pode ser interpretada como "dinheiro primitivo" de longo alcance e grande intensidade de uso.

As conchas - Spondylus ou mullu - receberam 19 citações no total, sendo que se destacaram mais no contexto mágico-religioso (13 citações).

\footnotetext{
${ }^{10}$ France Presse em Arequipa, Peru de 01/08/2001 (http://www.afp.com).
} 


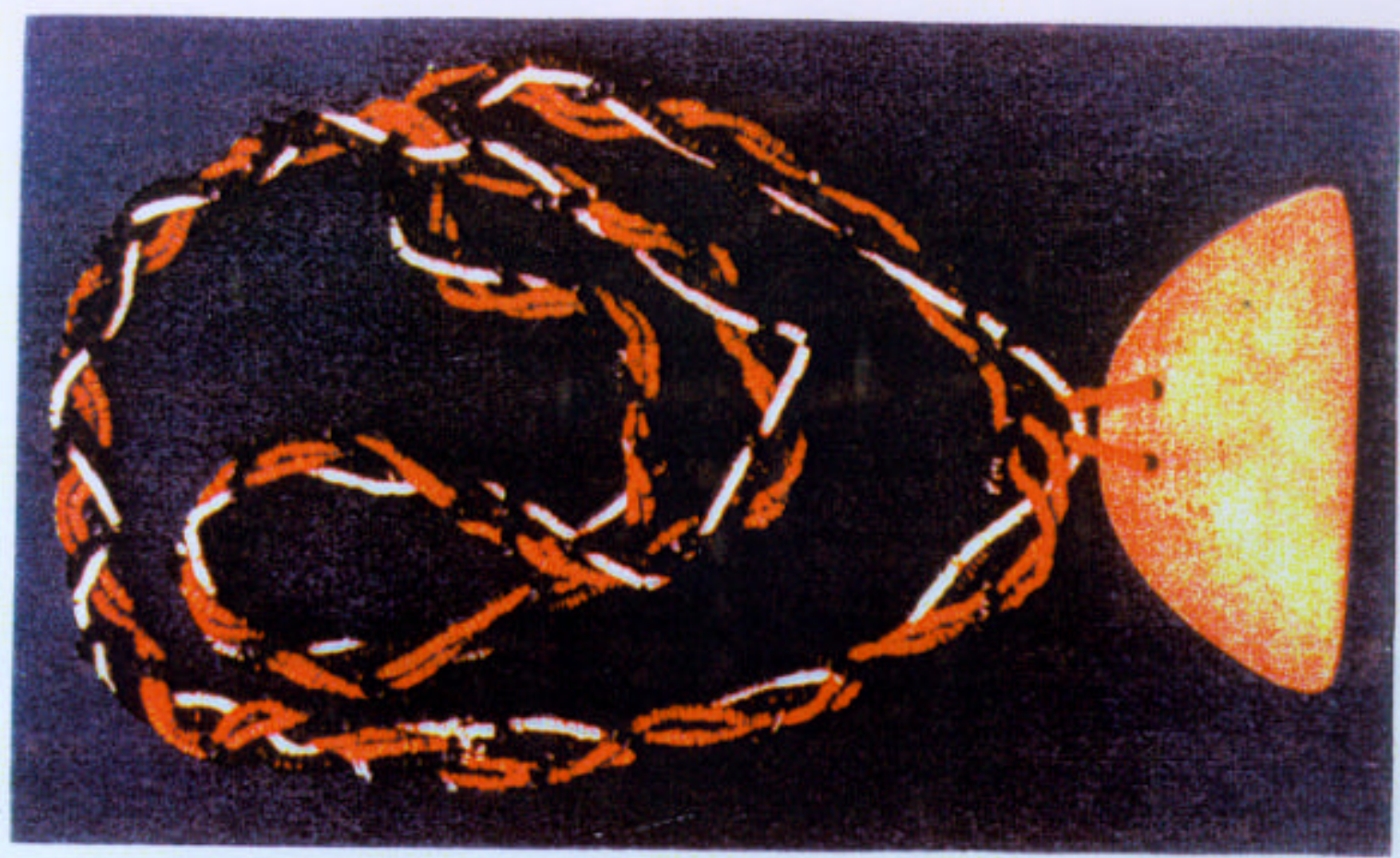

Colar de chaquiras rosas e brancas, procedentes do norte do Peru.

Fonte: Espinoza Soriano, W. Artesanos, transacciones, monedas y formas de pago en el mundo andino. Siglos XV y XVI. Banco Central de Reserva del Peru. Lima, 1987. Tomo II. 96.

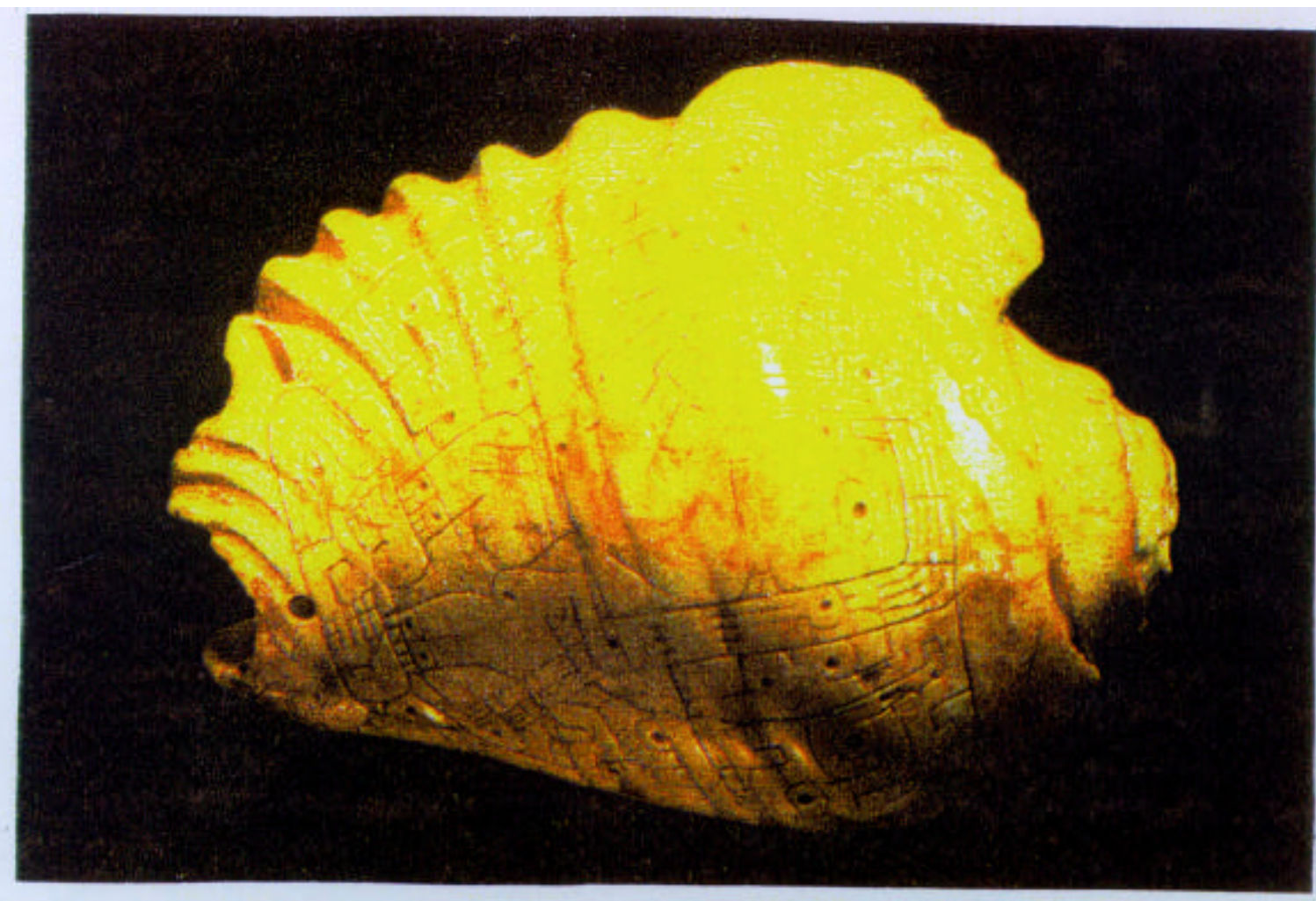

Exemplar de Strombus galeatus. (3.000 a. c.)

Fonte: Le Grand Atlas de L Archéologie. Encyclopedia Universalis. 
Além do contexto citado acima, as conchas apareceram somente como meio de pagamento (2 vezes), e como objeto de prestígio (4 vezes). Nos demais contextos, esse objeto não foi mencionado.

Nos textos, quando os cronistas europeus falam das conchas, sempre dão maior atenção às características rituais e simbólicas desse objeto, enfatizando o seu uso como oferenda aos deuses em troca de boa colheita, chuva ou da ausência de catástrofes ambientais.

Por meio das fontes arqueológicas podemos evidenciar o seu uso principalmente, em contextos de enterramentos e santuários. Considerando que também receberam um número significativo de citações no contexto de prestígio (4 vezes), tudo indica que as conchas, em particular, circulavam de forma restrita, ou seja, não foram mencionadas em todos os contextos estabelecidos pela pesquisa e - freqüentemente - tinham um destino: os sepultamentos de elite e santuários.

No caso da importância desses objetos, há uma contraposição entre a fonte escrita, contaminada pela cultura européia e a arqueologia que nos demonstra por meio dos seus vestígios, o alto valor e significado desse objeto no mundo andino.

As plumas, com total de 19 citações, apareceram no contexto de meio de pagamento, mágico-religioso e prestígio. Sendo que neste último surgiu com mais intensidade, com 11 referências.

Particularmente, no caso da pimenta do tipo ají, foi identificada 11 vezes: 2 vezes como meio de troca, 5 como meio de pagamento, 2 no contexto mágico-religioso e, finalmente, 2 vezes no contexto de prestígio.

Sua maior expressividade como meio de pagamento está de acordo com a tese de Martel (1983), segundo o qual o ají, circulava em níveis sociais baixos como uma espécie de troco miúdo. Por certo, devido ao baixo valor e estima por parte dos espanhóis que não lhe deram atenção ou não perceberam o significado, esse item é pouco mencionado nas crônicas. 
O cobre, foi o item que teve o menor número de identificações, com apenas 6 citações. Porém, as menções apareceram de forma equilibrada e bem distribuídas em todos os contextos, exceto o de entesouramento.

No que se refere ao cobre (hachitas e naipes), ao contrário de todos os outros artigos, não há evidências, arqueológicas ou etno-históricas, se havia controle por parte do Estado. Pode ser compreendido como "dinheiro primitivo" que circulava com mais intensidade em uma região restrita (norte do Peru e Equador onde são frequentemente encontradas), e em níveis sociais altos, visto que somente são achadas arqueológicamente em enterramento de pessoas da elite.

O cobre, com valor menor - para os espanhóis - do que o ouro e a prata, passou quase despercebido e raramente é mencionado ou é motivo de descrições mais cuidadosas nas fontes etno-históricas. Tanto as escavações arqueológicas quanto o trabalho clandestino e ilegal dos huaqueros peruanos demonstram que o principal destino do cobre eram os enterramentos. Ali, as hachitas de cobre foram encontradas em abundância.

Sua borda grossa e fragilidade física, adicionado aos fatos de que - na maioria das vezes - são encontradas arqueológicamente juntas em 'paquetes', e de possuir pesos e tamanhos que seguem um determinado padrão (Hosler et all, 1990), fortalecem a tese de que as hachitas atuavam como "dinheiro primitivo" e não como instrumento ou ferramenta de trabalho.

Por meio da análise geral das informações procedentes do catálogo, salta aos olhos que - exceto em relação ao cobre - em relação a todos os objetos o contexto mágico-religioso aparece em quantidade proporcionalmente muito maior que os demais contextos. Ou seja, todos os objetos aqui estudados e que desempenhavam a função de "dinheiro primitivo" no império Inca tinham um caráter ritual e mágico muito significativo. 
O fato de os três contextos mais expressivos em número de citações serem representados, respectivamente, pelo contexto mágico-religioso (esfera religiosa), prestígio (relacionado à esfera política e à ideologia), e - finalmente - meio de pagamento (esfera econômica propriamente dita), demonstra que todos os objetos pesquisados circulavam e tinham relevância em diferentes esferas sociais. Ou seja, a circulação e importância desses itens ultrapassam os limites de uma ou de outra esfera social. A esfera política, por sua vez, passa a fazer parte desse sistema se adicionarmos o uso político que o Estado fazia desses bens para alcançar objetivos de controle social e político de etnias locais que faziam parte do império.

Tudo indica que o Estado Inca controlava o acesso e a distribuição desses artigos e, além disso, como visto acima, não somente administrava, mas como também fazia uso político e também ideológico deles.

Segundo Goldstein (2000: 335), esses objetos considerados como "dinheiro primitivo" ou como artigos de luxo, tinham características míticas e religiosas, estruturavam a integração política entre elites geográficas e politicamente distintas. Isto significa que por meio desses objetos - entre outros fatores - o centro imperial Inca subvertia as hierarquias e políticas locais, convertendo os líderes regionais para o sistema de valores da cultura central.

Esses artigos, ao mesmo tempo em que diferenciavam a elite imperial, funcionavam como um vínculo de identificação das elites locais para com a elite central (Goldstein, 2000: 337). Portanto, como dito, além das características propriamente econômicas e do aspecto mítico, esses objetos desempenhavam também um papel fundamental no controle, estabilidade e manutenção do Estado Inca.

Segundo Earle (1990: 67), os especialistas (como, por exemplo, os mergulhadores que buscavam as conchas marinhas - o Spondylus - em profundidades relativamente altas de 15 a 50 metros), estavam ligados à elite ou à instituições do governo para quem eles produziam 
serviços especiais ou provinham artigos de luxo. Estes especialista existiam por causa das vantagens que ofereciam aos seus governadores.

Quanto maior o controle estatal sobre os artigos de subsistência como, por exemplo, a água e a terra, maior a complexidade social. Por outro lado, quanto mais o Estado controlava os artigos de luxo, mais garantia sua supremacia sobre todo o império.

No império Inca, cada região - dentro do sistema redistributivo - tinha o seu centro administrativo controlado por curacas que, por sua vez, representavam diretamente o Estado. Devido os altos custos em mover mercadorias por longas distâncias - visto as enormes extensões do império e dos quatro suyus - esses centros mantinham para si mesmos a produção local e somente os artigos mais valorizados eram enviados diretamente para a capital em Cuzco (Earle, 1990: 68).

Porém, esse sistema - de certa forma 'descentralizado' - poderia gerar revoltas e/ou rebeliões locais devido a fragilidade e/ou suscetibilidade dos recursos produzidos localmente, ou seja, as etnias locais poderiam se aproveitar do acesso aos próprios recursos produzidos para se rebelarem contra o governo central. Para solucionar esse problema o Estado fazia uso da 'wealth finance', política que consistia em obtenção, controle e utilização de objetos com alto valor de prestígio para pagamentos pessoais. Ou seja, o controle estatal desses objetos fortalecia os vínculos de dependência e inibia o crescimento de coalizões com a oposição (Earle, 1990: 68).

Nesse processo, a reciprocidade competitiva - tal como definida por Mauss desempenhava um papel fundamental na sedução de seguidores do império por meio dos objetos aqui pesquisados.

O indivíduo que possuía esses objetos, além do status e do prestígio, passava a ter direitos explícitos na economia de subsistência, já que no antigo Peru os artigos de luxo não eram facilmente conversíveis em artigos de subsistência (Earle, 1990: 69). 


\section{CONCLUSÃO}

Acreditamos que somente uma abordagem que leve em consideração e aprofunde o conhecimento sobre o aspecto multifacetado do "dinheiro primitivo" poderá contribuir para a compreensão da natureza do dinheiro como fenômeno social. Partindo do princípio de que a economia na região andina estava embedded/engastada nas demais esferas da sociedade, pudemos - com essa pesquisa - entender um pouco mais sobre quais objetos cumpriam quais papéis nas diferentes modalidades de interação social.

Por diversas razões e pela complexidade que representa o "dinheiro primitivo" é um assunto complicado, pois não existe um uso comum de categorias analíticas designadas para revelar distintas características em diferentes sistemas (Dalton, 1967: 255). Por isso, cada objeto deve ser tratado como único pois, desempenha funções especificas para finalidades também específicas.

O "dinheiro primitivo" desempenha muitas das funções do dinheiro que usamos atualmente, porém raramente todas elas.

$\mathrm{Na}$ sociedade Inca diferentes objetos exerciam diferentes funções, ou seja, não havia um determinado objeto que tivesse desempenhado todas as funções necessárias para ser considerado dinheiro, segundo a concepção moderna. Pode-se dizer que de todos os objetos que circularam e intermediavam as trocas entre os homens e os deuses no antigo Peru, nenhum se encaixa na categoria de dinheiro como o entendemos hoje. Isso, no entanto, não significa que a economia no império Inca era mais ou menos desenvolvida, mas simplesmente - era regida por um raciocínio diferente do nosso.

Tratamos nesta pesquisa apenas de salientar que o dinheiro na economia Inca existia, porém dentro de uma lógica totalmente diferente e com nuances e especificidades que 
ultrapassam nossa concepção atual do dinheiro como, por exemplo, o caráter mítico e religioso dos objetos estudados aqui.

Enquanto que o dinheiro atual é racional, positivo e impessoal; o "dinheiro primitivo" no antigo Peru tinha personalidade, usos sagrados e morais.

Nas economia de mercado, o dinheiro, sob uma forma única e universal, tem uma multiplicidade de funções: serve de meio de troca e de circulação dos bens, de meio de pagamento, de padrão de valor, constitui uma forma de armazenagem das riquezas. Nas sociedades não capitalistas, estas funções, no seu conjunto, não têm nenhuma razão especial para estarem associadas.

Como observado por Moniot (1976: 248), o "dinheiro primitivo" não constitui, em geral, um equivalente universal (a terra e o trabalho, em particular, não são, na maior parte das vezes, bens permutáveis), nem mesmo um equivalente geral: as trocas nas sociedades antigas estão encerradas em diferentes esferas mais ou menos estanques.

Ao ativar e/ou acionar diferentes esferas sociais, o "dinheiro primitivo", representado pelos objetos pesquisados, faz parte do que Marcel Mauss denominou 'fato social total'. Ou seja, cada um dos itens que desempenhavam o papel de "dinheiro primitivo" no antigo Peru detinham importância - simultaneamente - econômica, política, religiosa e também ideológica. Isto significa que as esferas sociais se sobrepõem atuando conjuntamente. O estudo desses objetos e da forma como funcionavam internamente na sociedade Inca, parece ser um microcosmo de como funcionava o mundo andino onde tudo estava mesclado e misturado. Para o cientista social, faz-se necessário entender o todo mesmo que por meio do particular, como no caso do "dinheiro primitivo" que representa apenas um dos aspectos da esfera econômica.

Enfim, é preciso dar à economia Inca e - consequentemente - ao "dinheiro primitivo" o caráter histórico, particular, específico e contextualizado para que possamos compreendê-lo e 
assim, a economia nas sociedades antigas. Pois, os princípios que governavam o império Inca não permitem que a economia seja isolada das relações sociais, políticas, religiosas e ideológicas. 


\section{PARTE II}

\section{METODOLOGIA PARA EXECUÇÃo DO CATÁLOGO}

Em primeiro lugar, foi realizada a leitura sistemática e criteriosa das fontes documentais selecionadas e, simultaneamente, a cópia literal de todas as passagens que citam diretamente os objetos de nosso interesse, ou seja, aqueles que serviam como "dinheiro primitivo".

O critério utilizado para a seleção dos objetos considerados relevantes para esta pesquisa, pautou-se pelos preceitos expostos no capítulo 2. Simultaneamente, foi levada em conta a bibliografia acerca do tema que - por meio de análises arqueológicas, etno-históricas e antropológicas - vem estudando essa categoria de objetos.

Foram selecionados os objetos que de alguma forma participavam e/ou desempenhavam um papel importante na vida econômica do antigo Peru.

Foi considerado que o uso de critérios rígidos e inflexíveis para determinar quais seriam os objetos que são considerados "dinheiro primitivo" não nos traria resultados claros, visto que a definição e conceituação desses objetos no antigo Peru depende de diversos e variados fatores.

Além dos quatro contextos e/ou funções do dinheiro, foram inseridos também no catálogo os itens reciprocidade e contexto mágico-religioso e objetos de prestígio, devido a dois motivos: 1. a grande freqüência que estes contextos aparecem nas crônicas em associação a algum objeto categorizado como "dinheiro primitivo"; e 2. a conhecida conotação e expressão extra-econômica do "dinheiro primitivo".

No processo de criação do catálogo, foi preciso extrema clareza nas definições de cada contexto específico em que o "dinheiro primitivo" circulava, portanto todos eles foram intensamente avaliados, até chegarmos às seguintes conclusões: 
1. Meio de Troca: quando determinado objeto participa diretamente nas trocas, como um meio de obtenção de produtos relacionados à esfera da sobrevivência. É uma troca comercial.

2. Meio de pagamento: quando determinado objeto é utilizado para pagar algo (uma dívida, um serviço ou um bem) a alguém, seja uma pessoa, um grupo ou o Estado.

3. Medida de valor: quando determinado objeto desempenha o papel de medida padronizada ou como referência mental de valor.

4. Entesouramento: quando determinado objeto é retirado de circulação e guardado sem conotações religiosas.

5. Reciprocidade: quando determinado objeto participa de trocas não relacionadas à sobrevivência, mas sim ao prestígio das pessoas ou grupos envolvidos nela. Neste caso inserimos os contextos de reciprocidade e troca de presentes entre chefes.

6. Contexto mágico-religioso: quando determinado objeto participa de trocas com a esfera religiosa como, por exemplo, oferenda aos mortos, sacrifícios e oferendas aos deuses.

7. Objetos de prestígio: quando determinado objeto ganha características externas e especiais e, dá ao seu portador maior prestígio. Indica hierarquia social.

Não obstante a divisão das categorias e/ou contextos estabelecidos, há vários deles que se sobrepõem.

No caso específico e particular desta pesquisa, no momento de decidir se o ouro e a prata seriam ou não incluídos em nossas análises, o fato de os espanhóis darem demasiada ênfase a esses metais colaborou inicialmente para a não inclusão. Porém, a decisão final foi a favor da inclusão pois, o ouro e a prata representavam itens importantes e de valor - mesmo que diferenciado - na cultura indígena. Há de se notar uma grande quantidade de citações desses objetos, no entanto, deve-se considerar simultaneamente, que a sede por metais por 
parte dos europeus faz com que esses objetos aparecessem muito mais do que deveriam de acordo com a concepção indígena de riqueza.

No caso das hachitas de cobre, foi considerado que todas vez que aparecesse a palavra cobre seria considerado como hachitas, visto esta palavra foi cunhada somente muito tempo depois da conquista espanhola. 


\section{CATÁl OGO}

\section{$\underline{\text { Ficha } N^{\circ} 1}$}

Autor: José de Acosta

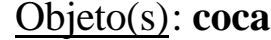

"En los Andes...da-se la yerba o árbol que llaman coca, que tan estimada es de los indios y tanto dinero vale su trato." (Libro Tercero, Capítulo 20:127)

\begin{tabular}{|c|c|c|c|c|c|c|}
\hline Meio de Troca & $\begin{array}{c}\text { Meio de } \\
\text { Pagamento }\end{array}$ & $\begin{array}{c}\text { Medida de } \\
\text { Valor }\end{array}$ & Entesouramento & Reciprocidade & $\begin{array}{c}\text { Mágico- } \\
\text { Religioso }\end{array}$ & $\begin{array}{c}\text { Objeto de } \\
\text { Prestígio }\end{array}$ \\
\hline & & & & & & $\mathrm{x}$ \\
\hline
\end{tabular}

\section{Ficha $\mathrm{N}^{\circ} 2$}

Autor: José de Acosta

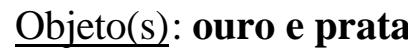

"Pero sobre todos estos usos, que son sencillos y naturales, halló la comunicación de los hombres el uso del dinero, el cual (como dijo el filósofo [Aristóteles]) es medida de todas las cosas; y siendo una cosa sola en la naturaleza, es todas en virtud, porque el dinero es comidas, y vestido y casa, y cabalgadura y cuanto los hombres han menester. Y así obedece todo al dinero, como dice el Sabio ${ }^{11}$. Para esta invención de hacer que una cosa fuese todas las cosas, guiados de natural instinto, eligiram los hombres la cosa más durable y más tratable, que es el metal, y entre los metales quisieron que aquéllos tuviesen principado en esta invención de ser dinero, que por su naturaleza eram más durables e incorruptibles, que son la plata y el oro. Los cuales no sólo entre los hebreos y asirios, y griegos y romanos, y otras naciones de Europa y Asia tuvieron estima, sino también entre las más remotas y bárbaras naciones del universo, como son los indios, así orientales como occidentales, donde el oro y plata fué tenida en precio y estima, y como tal usada en los templos y palacios, y ornato de reyes y nobles. Porque aunque se han hallado algunos bárbaros que no conocían la plata ni el oro, como cuentan los floridos, que tomaban las talegas o sacos en que iba el dinero, y al mismo dinero le dejaban echado por allé en la playa como a cosa inútil. Y Plínio refiere de los babitacos, que aborrecían el oro y por eso lo sepultavan donde nadie pudiesse servirse de él. Pero de estos floridos y de aquellos babitacos, há habido y hay dia pocos, y de los que estiman

\footnotetext{
${ }^{11}$ Eclesiastés, 10, $1^{\text {a }}$ : "Por el placer se hace el convite, y en vino alegra los vivos: y el dinero responde a todo". Nota do Autor.
} 
y buscan, y guardan el oro y la plata hay muchos, sin que tengan necessidad de aprender esto de los que han ido a Europa." (Libro Cuarto, Capítulo 2:142)

\begin{tabular}{|c|c|c|c|c|c|c|}
\hline Meio de Troca & $\begin{array}{c}\text { Meio de } \\
\text { Pagamento }\end{array}$ & $\begin{array}{c}\text { Medida de } \\
\text { Valor }\end{array}$ & Entesouramento & Reciprocidade & $\begin{array}{c}\text { Mágico- } \\
\text { Religioso }\end{array}$ & $\begin{array}{c}\text { Objeto de } \\
\text { Prestígio }\end{array}$ \\
\hline & & & & & $\mathrm{x}$ & $\mathrm{x}$ \\
\hline
\end{tabular}

Ficha $\mathrm{N}^{\circ} 3$

Autor: José de Acosta

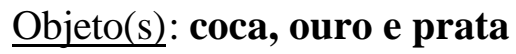

"No se halla que los indios usasen oro, ni plata, ni metal para moneda, ni para precio de las cosas; usábanlo para ornamento, como está dicho. Y así tenían en templos, y palacios, y sepulturas, grande suma y mil generos de vasijas de oro y plata. Para contratar y comprar, no tenían dinero sino trocaban unas cosas con otras, como de los antiguos refiere Homero y cuenta Plínio. Habia algunas cosas de más estima que corrían por precio en lugar de dinero, y hasta el día de hoy dura entre los indios esta costumbre, como en las provincias de Mexico usan del cacao, que es una frutilla, en lugar de dinero, y con ela rescatan lo que quieren. En el Pirú sirve lo mismo la coca, que es una hoja que los indios precian mucho, como en el Paraguay usan cuños de hierro por moneda, y en Santa Cruz de la Sierra, algodón tejido. Finalmente su modo de contratar de los indios, su comprar y vender, fué cambiar y rescatar cosa por cosa; y con ser los mercados grandíssimos y frecuentissímos, no les hizo falta el dinero ni habían menester terceros, porque todos estavan muy diestros en saber cuánto de qué cosa era justo dar por tanto de outra cosa." (Libro Cuarto, Capítulo 3:144)

\begin{tabular}{|c|c|c|c|c|c|c|}
\hline Meio de Troca & $\begin{array}{c}\text { Meio de } \\
\text { Pagamento }\end{array}$ & $\begin{array}{c}\text { Medida de } \\
\text { Valor }\end{array}$ & Entesouramento & Reciprocidade & $\begin{array}{c}\text { Mágico- } \\
\text { Religioso }\end{array}$ & $\begin{array}{c}\text { Objeto de } \\
\text { Prestígio }\end{array}$ \\
\hline $\mathrm{x}$ & & $\mathrm{x}$ & & & $\mathrm{x}$ & $\mathrm{x}$ \\
\hline
\end{tabular}

OBS: Neste caso, os contextos mágico-religioso e objetos de prestígio referem-se ao ouro e a prata. Meio de troca e medida de valor referem-se somente à coca.

\section{$\underline{\text { Ficha } N^{\circ} 4}$}

Autor: José de Acosta

\section{Objeto(s): ají}

"Pero la natural especería que dí dios a las Indias de Occidente, es la que en Castilla llaman pimienta de las Indias, y en Indias por vocablo general tomado de la primera tierra de islas que conquistaron, nombran ají, y en lengua del Cuzco se dice uchu, y en la de México chili. Esta es cosa ya bien conocida, y así hay poco de tratar de ella; sólo es de saber que cerca de 
los antiguos indios fué preciada y la llevaban a las partes donde no se da, por mercadería importante." (Libro Cuarto, Capítulo 20:177)

\begin{tabular}{|c|c|c|c|c|c|c|}
\hline Meio de Troca & $\begin{array}{c}\text { Meio de } \\
\text { Pagamento }\end{array}$ & $\begin{array}{c}\text { Medida de } \\
\text { Valor }\end{array}$ & Entesouramento & Reciprocidade & $\begin{array}{c}\text { Mágico- } \\
\text { Religioso }\end{array}$ & $\begin{array}{c}\text { Objeto de } \\
\text { Prestígio }\end{array}$ \\
\hline & & & & & & $\mathrm{x}$ \\
\hline
\end{tabular}

\section{Ficha $\mathrm{N}^{\circ} 5$}

Autor: José de Acosta

\section{Objeto(s): coca}

"Aunque el plátano es más provechoso, es más estimado el cacao en México, y la coca en el Pirú, y ambos a dos árboles son de no poca superstición." (Libro Cuarto, Capítulo 22:180)

\begin{tabular}{|c|c|c|c|c|c|c|}
\hline Meio de Troca & $\begin{array}{c}\text { Meio de } \\
\text { Pagamento }\end{array}$ & $\begin{array}{c}\text { Medida de } \\
\text { Valor }\end{array}$ & Entesouramento & Reciprocidade & $\begin{array}{c}\text { Mágico- } \\
\text { Religioso }\end{array}$ & $\begin{array}{c}\text { Objeto de } \\
\text { Prestígio }\end{array}$ \\
\hline & & & & & $\mathrm{x}$ & \\
\hline
\end{tabular}

\section{Ficha $N^{\circ} 6$}

Autor: José de Acosta

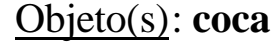

"En el Pirú no se da ${ }^{12}$, mas dáse la coca, que es otra superstición harto mayor y parece cosa de fábula. En realidad de verdad en sólo Potosi monta más de medio millión de pesos cada año la contratación de la coca, por gastarse de noventa a noventa y cinco mil cestos della, y aún el año de ochenta y tres, fueron cien mil. Vale un cesto de coca en el Cuzco, de dos pesos y seis tomines, y a cinco pesos ensayados; y es el género sobre que se hacen cuasi todas las baratas o mohatras, porque es mercadería de que hay gran expedición. Es pues la coca tan preciada, una hoja verde pequeña que nace en unos arbolillos de obra de un estado de alto; críase en tierras calidíssimas y muy húmedas; da este árbol cada cuatro meses esta hoja, que llaman allá tresmitas....Métenla con mucho orden en unos cestos largos u angostos, y cargan los carneros de la tierra, que van con esta mercadería a manadas, con mil, y dos mil y tres mil cestos." (Libro Cuarto, Capítulo 22:181)

\begin{tabular}{|l|l|l|l|l|l|l|}
\hline Meio de Troca & $\begin{array}{l}\text { Meio de } \\
\text { Pagamento }\end{array}$ & $\begin{array}{l}\text { Medida de } \\
\text { Valor }\end{array}$ & Entesouramento & Reciprocidade & $\begin{array}{l}\text { Mágico- } \\
\text { Religioso }\end{array}$ & $\begin{array}{l}\text { Objeto de } \\
\text { Prestígio }\end{array}$ \\
\hline & \multicolumn{2}{|c|}{$\mathrm{x}$} & & & $\mathrm{x}$ & \\
\hline
\end{tabular}




\section{Ficha $\mathrm{N}^{\circ} 7$}

Autor: José de Acosta

\section{Objeto(s): coca}

"Los indios la aprecian sobre manera, y en tiempo de los reyes ingas, no era lícito a los plebeyos usar la coca sin licencia del Inga o su gobernador. El uso es traerla en la boca y mascarla, chupándola; no la tragan; dicen que les da gran esfuerzo, y es singular regalo para ellos. Muchos hombres graves lo tienen por superstición y cosa de pura imaginación....A ellos les sabe bien y dicen les hace provecho, y dan su dinero de buena gana por ella, y con ella rescatan como si fuese moneda, cuanto quieren. Todo podría bien pasar si no fuese el beneficio y trato de ella con riesgo suyo y ocupación de tanta gente. Los señores ingas usaban la coca por cosa real y regalada, y en sus sacrificios era la cosa que más ofrecían, quemándola en honor de sus ídolos." (Libro Cuarto, Capítulo 22:181-182)

\begin{tabular}{|c|c|c|c|c|c|c|}
\hline Meio de Troca & $\begin{array}{c}\text { Meio de } \\
\text { Pagamento }\end{array}$ & $\begin{array}{c}\text { Medida de } \\
\text { Valor }\end{array}$ & Entesouramento & Reciprocidade & $\begin{array}{c}\text { Mágico- } \\
\text { Religioso }\end{array}$ & $\begin{array}{c}\text { Objeto de } \\
\text { Prestígio }\end{array}$ \\
\hline $\mathrm{x}$ & $\mathrm{x}$ & & & $\mathrm{x}$ & $\mathrm{x}$ & $\mathrm{x}$ \\
\hline
\end{tabular}

\section{Ficha $N^{\circ} 8$}

Autor: José de Acosta

\section{Objeto(s): plumas}

"Toman estas plumas tan chiquitas y delicadas de aquellos pajarillos que llaman en el Pirú tominejos, o de otros semejantes, que tienen perfectíssimas colores en su pluma. Fuera de imaginería, usaron los indios otras muchas obras de pluma muy preciosas, especialmente para ornato de los reyes y señores, y de los templos e ídolos. Porque hay otros pájaros y aves grandes de excelentes plumas y muy finas, de que hacían bizarros plumajes y penachos, especialmente cuando iban a la guerra, y con oro y plata concertaban estas obras de plumería rica, que era cosa de mucho precio....De manera que de los pájaros no sólo la carne para comer y el canto para deleite, y la pluma para ornato y gala..." (Libro Cuarto, Capítulo 37:204-205)

\begin{tabular}{|c|c|c|c|c|c|c|}
\hline Meio de Troca & $\begin{array}{c}\text { Meio de } \\
\text { Pagamento }\end{array}$ & $\begin{array}{c}\text { Medida de } \\
\text { Valor }\end{array}$ & Entesouramento & Reciprocidade & $\begin{array}{c}\text { Mágico- } \\
\text { Religioso }\end{array}$ & $\begin{array}{c}\text { Objeto de } \\
\text { Prestígio }\end{array}$ \\
\hline & & & & & $\mathrm{x}$ & $\mathrm{x}$ \\
\hline
\end{tabular}

\footnotetext{
12 Não há o cacau.
} 


\section{Ficha $\mathrm{N}^{\circ} 9$}

Autor: José de Acosta

Objeto(s): coca, plumas

"A este tono cualquier cosa que tenga extrañeza entre las de su género, les parecía que tenía divindad, ya hasta hacer esto con pedrezuelas y metales, y aún raíces y frutos de la tierra, como en las raíces que llaman papas hay unas extrañas, a quien ellos ponen nombre llallahuas, y las besan y las adoran. Adoran también osos, leones, tigres y culebras, porque no les hagan mal. Y como son tales sus dioses, así son danosas las cosas que les ofrecen cuando los adoran. Usan cuando van camino, echar en los mismos caminos o encrucijadas, en los cerros, y principalmente en las cumbres que llaman Apachitas, Calzados viejos y plumas, coca mascada, que es una yerba que muchu usan, u cuando no pueden, más siquiera una piedra, y todo esto es como ofrenda para que les dejen pasar y les den fuerzas, y dicen que las cobran con esto, como se refiere en un Concilo Provincial del Pirú." (Libro Quinto, Capítulo 5:224)

\begin{tabular}{|c|c|c|c|c|c|c|}
\hline Meio de Troca & $\begin{array}{c}\text { Meio de } \\
\text { Pagamento }\end{array}$ & $\begin{array}{c}\text { Medida de } \\
\text { Valor }\end{array}$ & Entesouramento & Reciprocidade & $\begin{array}{c}\text { Mágico- } \\
\text { Religioso }\end{array}$ & $\begin{array}{c}\text { Objeto de } \\
\text { Prestígio }\end{array}$ \\
\hline & & & & & $\mathrm{x}$ & \\
\hline
\end{tabular}

\section{$\underline{\text { Ficha } \mathrm{N}^{\circ} 10}$}

Autor: José de Acosta

\section{Objeto(s): coca, plumas, conchas, ouro e prata}

"En el Pirú usaron sacrificar coca, que es una yerba que mucho estiman, y maíz, que es su trigo, y plumas de colores y chaquira, que ellos llaman mollo, y conchas de la mar, y a veces oro y plata, figurando de ello animalejos; también ropa fina de Cumbi y madera labrada y olorosa, y muy ordinariamente cebo quemado. Eran estas ofrendas o sacrificios para alcanzar buenos temporales o salud, o librarse de peligros y males." (Libro Quinto, Capítulo $18: 246)$

\begin{tabular}{|c|c|c|c|c|c|c|}
\hline Meio de Troca & $\begin{array}{c}\text { Meio de } \\
\text { Pagamento }\end{array}$ & $\begin{array}{c}\text { Medida de } \\
\text { Valor }\end{array}$ & Entesouramento & Reciprocidade & $\begin{array}{c}\text { Mágico- } \\
\text { Religioso }\end{array}$ & $\begin{array}{c}\text { Objeto de } \\
\text { Prestígio }\end{array}$ \\
\hline & & & & & $x$ & \\
\hline
\end{tabular}

\section{Ficha $N^{\circ} 11$}

Autor: José de Acosta

\section{Objeto(s): conchas}

"...también sacrificaban u ofrecian conchas de la mar, que llamabán mollo, y ofrecíanlas a las fuentes y manantiales, diciendo que las conchas eran hijas de la mar, madre de todas las 
aguas. Tienen diferentes nombres según la color, y así sirven a diferentes efectos. Usan de estas conchas cuasi en todas las maneras de sacrifícios, y aún el día de hoy echan algunos el mollo molido en la chicha por superstición." (Libro Quinto, Capítulo 18:247-248).

\begin{tabular}{|c|c|c|c|c|c|c|}
\hline Meio de Troca & $\begin{array}{c}\text { Meio de } \\
\text { Pagamento }\end{array}$ & $\begin{array}{c}\text { Medida de } \\
\text { Valor }\end{array}$ & Entesouramento & Reciprocidade & $\begin{array}{c}\text { Mágico- } \\
\text { Religioso }\end{array}$ & $\begin{array}{c}\text { Objeto de } \\
\text { Prestígio }\end{array}$ \\
\hline & & & & & $\mathrm{x}$ & \\
\hline
\end{tabular}

Ficha $N^{\circ} 12$

Autor: José de Acosta

\section{Objeto(s): conchas, plumas, ouro e prata}

"...luego se hacían fiestas muy solenes y gran multitud de sacrificios, con gran cuantidad de vasos de oro, y plata, y muchas ovejuelas pequeñas hechas de lo mismo, y gran suma de ropa de cumbi, muy bien obrada, grande y pequeña, y muchas conchas de la mar de todas maneras, y muchas plumas ricas, y mil carneros que habían de ser de diferentes colores, y de todo esto se hacia sacrificio." (Libro Sexto, Capítulo 12:295)

\begin{tabular}{|c|c|c|c|c|c|c|}
\hline Meio de Troca & $\begin{array}{c}\text { Meio de } \\
\text { Pagamento }\end{array}$ & $\begin{array}{c}\text { Medida de } \\
\text { Valor }\end{array}$ & Entesouramento & Reciprocidade & $\begin{array}{c}\text { Mágico- } \\
\text { Religioso }\end{array}$ & $\begin{array}{c}\text { Objeto de } \\
\text { Prestígio }\end{array}$ \\
\hline & & & & & $\mathrm{x}$ & \\
\hline
\end{tabular}

$\underline{\text { Ficha } \mathrm{N}^{\circ} 13}$

Autor: Francisco de Ávila

\section{Objeto(s): coca}

"Y cuando debían empezar algún trabajo difícil, a él adoraban, arrojando hojas de coca al suelo: 'has que recuerde esto, que lo adivine Cuniraya Viracocha', diciendo, y sin que pudieran ver a Viracocha, los muy antiguos le hablaban y adoraban." (Capítulo I, p. 21)

\begin{tabular}{|c|c|c|c|c|c|c|}
\hline Meio de Troca & $\begin{array}{c}\text { Meio de } \\
\text { Pagamento }\end{array}$ & $\begin{array}{c}\text { Medida de } \\
\text { Valor }\end{array}$ & Entesouramento & Reciprocidade & $\begin{array}{c}\text { Mágico- } \\
\text { Religioso }\end{array}$ & $\begin{array}{c}\text { Objeto de } \\
\text { Prestígio }\end{array}$ \\
\hline & & & & & $\mathrm{x}$ & \\
\hline
\end{tabular}

$\underline{\text { Ficha } \mathrm{N}^{\circ} 14}$

Autor: Francisco de Ávila

\section{Objeto(s): coca}

"Y hasta ahora está allí, con sus piernas humanas y su sexo visibles; está sobre el camino, tal como Huatyacuri la puso. Y le ofrendan coca, hoy mismo, sí, por cualquier motivo." (Capítulo V, p. 43) 


\begin{tabular}{|c|c|c|c|c|c|c|}
\hline Meio de Troca & $\begin{array}{c}\text { Meio de } \\
\text { Pagamento }\end{array}$ & $\begin{array}{c}\text { Medida de } \\
\text { Valor }\end{array}$ & Entesouramento & Reciprocidade & $\begin{array}{c}\text { Mágico- } \\
\text { Religioso }\end{array}$ & $\begin{array}{c}\text { Objeto de } \\
\text { Prestígio }\end{array}$ \\
\hline & & & & & $\mathrm{x}$ & \\
\hline
\end{tabular}

$\underline{\text { Ficha } \mathrm{N}^{\circ} 15}$

Autor: Francisco de Ávila

\section{Objeto(s): coca, mullu}

"En esse momento, vino un hombre llorando intensamente; traía a su hijo; llevaba tambiém mullo, coca y un potaje selecto llamado ticti, 'Para que los tome Huallallo', decía. Uno de los cuerpos de Pariacaca le preguntó: 'Hijo, ¿adonde vas llorando tan tristemente?' entonces el hombre contestó: 'Padre: llevo este hijo mío, tan amado, para servírselo a Huallallo'. Luego de oírlo, Pariacaca le dijo: 'No le lleves, hijo. Vuelve a tu pueblo. Dame a mí las otras ofrendas y vuelve con tu hijo a tu pueblo." (Capítulo VIII, p. 57)

\begin{tabular}{|c|c|c|l|l|c|c|}
\hline Meio de Troca & $\begin{array}{c}\text { Meio de } \\
\text { Pagamento }\end{array}$ & $\begin{array}{c}\text { Medida de } \\
\text { Valor }\end{array}$ & Entesouramento & Reciprocidade & $\begin{array}{c}\text { Mágico- } \\
\text { Religioso }\end{array}$ & $\begin{array}{c}\text { Objeto de } \\
\text { Prestígio }\end{array}$ \\
\hline & & & & & $\mathrm{x}$ & \\
\hline
\end{tabular}

$\underline{\text { Ficha } \mathrm{N}^{\circ} 16}$

Autor: Francisco de Ávila

\section{Objeto(s): coca}

"Adoraban ofreciendo una cría de llama, y si no la tenían, llevando una gran bolsa de coca." (capítulo IX, p. 67)

\begin{tabular}{|c|c|c|c|c|c|c|}
\hline Meio de Troca & $\begin{array}{c}\text { Meio de } \\
\text { Pagamento }\end{array}$ & $\begin{array}{c}\text { Medida de } \\
\text { Valor }\end{array}$ & Entesouramento & Reciprocidade & $\begin{array}{c}\text { Mágico- } \\
\text { Religioso }\end{array}$ & $\begin{array}{c}\text { Objeto de } \\
\text { Prestígio }\end{array}$ \\
\hline & & & & & $\mathrm{x}$ & \\
\hline
\end{tabular}

Ficha $\mathrm{N}^{\circ} 17$

Autor: Francisco de Ávila

\section{Objeto(s): coca}

"...de sitios muy lejanos, de unas y otras zonas yuncas, de todas, venían, con su ticti (potaje de comida), con su coca, con todas las cosas que debían ofrendarse durante la adoracíon..." (Capítulo IX, p. 71)

\begin{tabular}{|c|c|c|c|c|c|c|}
\hline Meio de Troca & $\begin{array}{c}\text { Meio de } \\
\text { Pagamento }\end{array}$ & $\begin{array}{c}\text { Medida de } \\
\text { Valor }\end{array}$ & Entesouramento & Reciprocidade & $\begin{array}{c}\text { Mágico- } \\
\text { Religioso }\end{array}$ & $\begin{array}{c}\text { Objeto de } \\
\text { Prestígio }\end{array}$ \\
\hline & & & & & $\mathrm{x}$ & \\
\hline
\end{tabular}


$\underline{\text { Ficha } \mathrm{N}^{\circ} 18}$

Autor: Francisco de Ávila

Objeto(s): coca

"...luego, iban a saludar al agua donde está Anchicara, y al tiempo saludarlo, le ofrendan un poco de coca." (Capítulo XXX, p. 167)

\begin{tabular}{|c|c|c|c|c|c|c|}
\hline Meio de Troca & $\begin{array}{c}\text { Meio de } \\
\text { Pagamento }\end{array}$ & $\begin{array}{c}\text { Medida de } \\
\text { Valor }\end{array}$ & Entesouramento & Reciprocidade & $\begin{array}{c}\text { Mágico- } \\
\text { Religioso }\end{array}$ & $\begin{array}{c}\text { Objeto de } \\
\text { Prestígio }\end{array}$ \\
\hline & & & & & $\mathrm{x}$ & \\
\hline
\end{tabular}

$\underline{\text { Ficha } \mathrm{N}^{\circ} 19}$

Autor: Francisco de Ávila

Objeto(s): coca

"Pero no dejaba de ir ninguna persona, hombre o mujer; salía la gente de todas partes y ofrendaba cada quien, a solas, coca u chicha durante el acto de cerrar la boca del estanque." (Capítulo XXXI, p. 181)

\begin{tabular}{|c|c|c|c|c|c|c|}
\hline Meio de Troca & $\begin{array}{c}\text { Meio de } \\
\text { Pagamento }\end{array}$ & $\begin{array}{c}\text { Medida de } \\
\text { Valor }\end{array}$ & Entesouramento & Reciprocidade & $\begin{array}{c}\text { Mágico- } \\
\text { Religioso }\end{array}$ & $\begin{array}{c}\text { Objeto de } \\
\text { Prestígio }\end{array}$ \\
\hline & & & & & $\mathrm{x}$ & \\
\hline
\end{tabular}

Ficha $N^{\circ} 20$

Autor: Francisco de Ávila

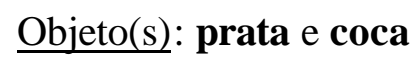

"Y tambiém, muchísima gente possedora de plata, cuando todavía ¡ay!, no habían aprendido lo amandado por la voz del verdadero Dios, entonces, en la fiesta de Pariacaca o en otros turnos de fiesta, cuando todas sus fuerzas, todo cuanto obsequiaban a cambio de la coca, y buscando dinero, también por la misma causa, aún cuando tuvieran que esperar tres o cuatro anõs y los pobres penando durante todos estos años, clamando: ¿Adónde encontraré la coca?." (p. 191-193)

\begin{tabular}{|c|c|c|c|c|c|c|}
\hline Meio de Troca & $\begin{array}{c}\text { Meio de } \\
\text { Pagamento }\end{array}$ & $\begin{array}{c}\text { Medida de } \\
\text { Valor }\end{array}$ & Entesouramento & Reciprocidade & $\begin{array}{c}\text { Mágico- } \\
\text { Religioso }\end{array}$ & $\begin{array}{c}\text { Objeto de } \\
\text { Prestígio }\end{array}$ \\
\hline $\mathrm{x}$ & & & & & & \\
\hline
\end{tabular}

\section{Ficha $\mathrm{N}^{\circ} 21$}

Autor: Blas Valera

\section{Objeto (s): ouro e prata}


"Y por esta via comenzaron los ídolos de piedra, de madera, de oro, plata, etc., que decían ellos representar a los dioses que estaban en el cielo; aunque después dijeron que tambiém aquellos eran las mismas ideas". (p. 8).

\begin{tabular}{|c|c|c|c|c|c|c|}
\hline Meio de Troca & $\begin{array}{c}\text { Meio de } \\
\text { Pagamento }\end{array}$ & $\begin{array}{c}\text { Medida de } \\
\text { Valor }\end{array}$ & Entesouramento & Reciprocidade & $\begin{array}{c}\text { Mágico- } \\
\text { Religioso }\end{array}$ & $\begin{array}{c}\text { Objeto de } \\
\text { Prestígio }\end{array}$ \\
\hline & & & & & $\mathrm{x}$ & $\mathrm{x}$ \\
\hline
\end{tabular}

Ficha $\mathrm{N}^{\circ} 22$

Autor: Blas Valera

Objeto (s): coca, plumas, conchas, ouro e prata

"Mieses, raíces, hierbas medicinales, en especial las dos que llaman coca y sayre sacrificaban;

- sayre es la que por outro nombre dicen tabaco; - plumas de aves, conchas de la mar, o granos hechos destas conchas, llamadas mollo; ropa de lana, oro, plata, metal, madera olorosa, aunque esta madera olorosa no se hacía por via de sacrificio, sino para serviese de leña para quemar todo lo dicho; sino que era superstición en que la leña fuese olorosa, como lo era también en escoger las cabezas de ganado que fuesen de tal edad y de tal color, y no de outra manera". (p. 9).

\begin{tabular}{|c|c|c|c|c|c|c|}
\hline Meio de Troca & $\begin{array}{c}\text { Meio de } \\
\text { Pagamento }\end{array}$ & $\begin{array}{c}\text { Medida de } \\
\text { Valor }\end{array}$ & Entesouramento & Reciprocidade & $\begin{array}{c}\text { Mágico- } \\
\text { Religioso }\end{array}$ & $\begin{array}{c}\text { Objeto de } \\
\text { Prestígio }\end{array}$ \\
\hline & & & & & $\mathrm{x}$ & \\
\hline
\end{tabular}

\section{Ficha $\mathrm{N}^{\circ} 23$}

Autor: Blas Valera

Objeto (s): ouro e prata.

"Sus templos eran siempre de una nave, capaces, y modo de capilla mayor, y en la pared hacían los altares de piedra para poner el ídolo de oro o de plata, y conforme era el ídolo, tal ornato tenía el templo y altar." (p. 13).

\begin{tabular}{|c|c|c|c|c|c|c|}
\hline Meio de Troca & $\begin{array}{c}\text { Meio de } \\
\text { Pagamento }\end{array}$ & $\begin{array}{c}\text { Medida de } \\
\text { Valor }\end{array}$ & Entesouramento & Reciprocidade & $\begin{array}{c}\text { Mágico- } \\
\text { Religioso }\end{array}$ & $\begin{array}{c}\text { Objeto de } \\
\text { Prestígio }\end{array}$ \\
\hline & & & & & $\mathrm{x}$ & \\
\hline
\end{tabular}

\section{Ficha $\mathrm{N}^{\circ} 24$}

Autor: Blas Valera

Objeto (s): ouro 
"El templo del sol, que agora es la iglesia de Santo Domingo, había outro altar, y en el hueco de la pared un ídolo de oro pintado como sol con sus rayos, por lo cual el altar y las paredes estaban cubiertas de chapas de oro, y aún el betún del edificio es de oro derretido". (p. 13).

\begin{tabular}{|c|c|c|c|c|c|c|}
\hline Meio de Troca & $\begin{array}{c}\text { Meio de } \\
\text { Pagamento }\end{array}$ & $\begin{array}{c}\text { Medida de } \\
\text { Valor }\end{array}$ & Entesouramento & Reciprocidade & $\begin{array}{c}\text { Mágico- } \\
\text { Religioso }\end{array}$ & $\begin{array}{c}\text { Objeto de } \\
\text { Prestígio }\end{array}$ \\
\hline & & & & & $\mathrm{x}$ & $\mathrm{x}$ \\
\hline
\end{tabular}

\section{$\underline{\text { Ficha } \mathrm{N}^{\circ} 25}$}

Autor: Blas Valera

\section{Objeto(s): coca, ouro, prata e conchas}

"Estos eran como siervos y ministros de los de la primera y segunda diferencia. Su oficio principal era aderezar los templos, limpiarlos y proveer de todo lo necesario para los sacrificios: leña, flores, ramos, animales, ropa, coca, sebo, conchas, pan, vino, mieses, frutas, ollas, asadores, platos, tazas de oro y de plata." (p. 29)

\begin{tabular}{|c|c|c|c|c|c|c|}
\hline Meio de Troca & $\begin{array}{c}\text { Meio de } \\
\text { Pagamento }\end{array}$ & $\begin{array}{c}\text { Medida de } \\
\text { Valor }\end{array}$ & Entesouramento & Reciprocidade & $\begin{array}{c}\text { Mágico- } \\
\text { Religioso }\end{array}$ & $\begin{array}{c}\text { Objeto de } \\
\text { Prestígio }\end{array}$ \\
\hline & & & & & $\mathrm{x}$ & \\
\hline
\end{tabular}

$\underline{\text { Ficha } \mathrm{N}^{\circ} 26}$

Autor: Polo de Ondegardo

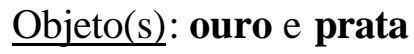

"...porque en la gente común solo se tenía respecto a que no padesçiezen neçeszidad. Lo mismo hacían en el tributo de oro y plata, que en las prouinçias donde auía minas echavan a sacallo cierta cantidad de indios y todo lo que se hallava se enviava cada un año al inga..."

(p. 137)

\begin{tabular}{|c|c|c|c|c|c|c|}
\hline Meio de Troca & $\begin{array}{c}\text { Meio de } \\
\text { Pagamento }\end{array}$ & $\begin{array}{c}\text { Medida de } \\
\text { Valor }\end{array}$ & Entesouramento & Reciprocidade & $\begin{array}{c}\text { Mágico- } \\
\text { Religioso }\end{array}$ & $\begin{array}{c}\text { Objeto de } \\
\text { Prestígio }\end{array}$ \\
\hline & $\mathrm{x}$ & & & & & \\
\hline
\end{tabular}

\section{$\underline{\text { Ficha } \mathrm{N}^{\circ} 27}$}

Autor: Polo de Ondegardo

\section{Objeto(s): ouro e prata}

"Lo que el inga hazía de todo este tributo también está averiguado, porque si era oro y plata, todo lo hazía vasos y ornatos de las cosas de su religión, y enterrávanse con ello..." (p. 150) 


\begin{tabular}{|c|c|c|c|c|c|c|}
\hline Meio de Troca & $\begin{array}{c}\text { Meio de } \\
\text { Pagamento }\end{array}$ & $\begin{array}{c}\text { Medida de } \\
\text { Valor }\end{array}$ & Entesouramento & Reciprocidade & $\begin{array}{c}\text { Mágico- } \\
\text { Religioso }\end{array}$ & $\begin{array}{c}\text { Objeto de } \\
\text { Prestígio }\end{array}$ \\
\hline & $\mathrm{x}$ & & & & $\mathrm{x}$ & \\
\hline
\end{tabular}

\section{$\underline{\text { Ficha } \mathrm{N}^{\circ} 28}$}

Autor: Betanzos

\section{Objeto(s): coca}

"...agradesció a todos ellos y luego mandó sacar muchas cosas como fueron ondas y petacas de coca y ciertas piezas de ropa fina y otras muy muchas cosas que entre ellos son muy preciadas todas las cuales fueron traídas delante del y siendo allí él mismo por sus manos las dio e repartió a aquellos señores y esto hecho mandóles dar a beber y que ansi mismo les fuese repartido cierta cantidad de coca y esto hecho Viracocha Ynga se levantó en pie y les agradesció la voluntad e amor que a él y a su hijo le mostraban y tenían y díjoles el mes y tiempo en que habían de enviarle sus indios e gentes para que edificasen su pueblo e ansi los señores se levantaron en pie y quedando con él de se los enviar como dicho tenían le hicieron su acatamiento e ansi se despidieron del donde le dejaremos e hablaremos de Ynga Yupangue." (p. 42)13

\begin{tabular}{|c|c|c|c|c|c|c|}
\hline Meio de Troca & $\begin{array}{c}\text { Meio de } \\
\text { Pagamento }\end{array}$ & $\begin{array}{c}\text { Medida de } \\
\text { Valor }\end{array}$ & Entesouramento & Reciprocidade & $\begin{array}{c}\text { Mágico- } \\
\text { Religioso }\end{array}$ & $\begin{array}{c}\text { Objeto de } \\
\text { Prestígio }\end{array}$ \\
\hline & & & & $\mathrm{x}$ & & $\mathrm{x}$ \\
\hline
\end{tabular}

\section{$\underline{\text { Ficha } \mathrm{N}^{\circ} 29}$}

\section{Autor: Betanzos}

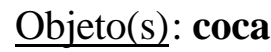

"...y allí luego mandó que todos los de la ciudad ansi hombres como mujeres viniesen a hacer sus sacrificios allí a la casa del sol los cuales sacrificios que ansi la gente común hizo fue quemar cierto maiz y coca en aquel fuego que ansi era hecho entrando cada uno destos uno a uno y descalzos los ojos bajos y al salir que ansi salían después de haber hecho su sacrificio cada uno destos por sí mandó Ynga Yupangue." (p. 45)

\begin{tabular}{|c|c|c|c|c|c|c|}
\hline Meio de Troca & $\begin{array}{c}\text { Meio de } \\
\text { Pagamento }\end{array}$ & $\begin{array}{c}\text { Medida de } \\
\text { Valor }\end{array}$ & Entesouramento & Reciprocidade & $\begin{array}{c}\text { Mágico- } \\
\text { Religioso }\end{array}$ & $\begin{array}{c}\text { Objeto de } \\
\text { Prestígio }\end{array}$ \\
\hline & & & & & $\mathrm{x}$ & \\
\hline
\end{tabular}

\footnotetext{
13 A numeração de páginas do texto de Betanzos corresponde à uma versão extraída da Internet (http://www.cervantesvirtual.org). Caso a formatação original seja modificada consequentemente, a paginação será diferente.
} 


\section{$\underline{\text { Ficha } \mathrm{N}^{\circ} 30}$}

Autor: Betanzos

\section{Objeto(s): pluma e ouro}

"...él había de estar en la cual casa estaba puesto un escaño hecho de madera y muy bien cubierto de una pluma de pájaros tornasoles de diversos colores de las cuales y con las cuales era muy vistosamente labrado en el cual escaño puso Ynga Yupanga el bulto del ídolo y siendo allí puesto hizo traer un brasero de oro e siendo encendido en el fuego mandóle poner delante del ídolo en el cual fuego e brasero hizo hechar ciertos pajaricos e ciertos granos de maiz e derramar encima del tal fuego cierta chicha." (p. 46)

\begin{tabular}{|c|c|c|c|c|c|c|}
\hline Meio de Troca & $\begin{array}{c}\text { Meio de } \\
\text { Pagamento }\end{array}$ & $\begin{array}{c}\text { Medida de } \\
\text { Valor }\end{array}$ & Entesouramento & Reciprocidade & $\begin{array}{c}\text { Mágico- } \\
\text { Religioso }\end{array}$ & $\begin{array}{c}\text { Objeto de } \\
\text { Prestígio }\end{array}$ \\
\hline & & & & & $\mathrm{x}$ & \\
\hline
\end{tabular}

\section{Ficha $\mathrm{N}^{\circ} 31$}

Autor: Betanzos

\section{Objeto(s): ouro}

"...era en aquella solenidad como que hacían sacrificio a sus ídolos y al poner que la piedra se puso enmedio de la plaza del Cuzco hízose en ella un gran hoyo primero donde todos los de la ciudad chicos y grandes ofrescieron al sol las piezas de oro que les pareció y esto ofrescido cerraron el hoyo encima del cual hicieron y edificaron una pila de cantería de altor de medio estado y en la redondez de la pila enterraron unos bultos de oro de largor de un dedo y del mismo gordor cada uno y estos bulticos que ansi enterraron en torno de la pila antes que los metiesen debajo de tierra..." (p. 47)

\begin{tabular}{|c|c|c|c|c|c|c|}
\hline Meio de Troca & $\begin{array}{c}\text { Meio de } \\
\text { Pagamento }\end{array}$ & $\begin{array}{c}\text { Medida de } \\
\text { Valor }\end{array}$ & Entesouramento & Reciprocidade & $\begin{array}{c}\text { Mágico- } \\
\text { Religioso }\end{array}$ & $\begin{array}{c}\text { Objeto de } \\
\text { Prestígio }\end{array}$ \\
\hline & & & & & $\mathrm{x}$ & \\
\hline
\end{tabular}

\section{$\underline{\text { Ficha } \mathrm{N}^{\circ} 32}$}

\section{Autor: Betanzos}

\section{Objeto(s): coca}

"Ynga Yupangue saludándole como a hijo del sol se tornaron a sentar e ansi mismo comenzaron a beber de la chicha que a según ellos dícen había muy mucha y en muy gran cantidad y luego les fue traído allí muy mucha coca y repartida entre todos ellos y esto ansi hecho se tornaron a levantar e hicieron ansi mismo como habeis oído su canto y baile la cual fiesta duró seis días en fín de los cuales el Ynga les dijo..." (p. 53) 


\begin{tabular}{|c|c|c|c|c|c|c|}
\hline Meio de Troca & $\begin{array}{c}\text { Meio de } \\
\text { Pagamento }\end{array}$ & $\begin{array}{c}\text { Medida de } \\
\text { Valor }\end{array}$ & Entesouramento & Reciprocidade & $\begin{array}{c}\text { Mágico- } \\
\text { Religioso }\end{array}$ & $\begin{array}{c}\text { Objeto de } \\
\text { Prestígio }\end{array}$ \\
\hline & & & & $\mathrm{x}$ & & \\
\hline
\end{tabular}

$\underline{\text { Ficha } N^{\circ} 33}$

Autor: Betanzos

\section{Objeto(s): coca, ouro e prata}

"...y llegados allí hagan su sacrificio ofreciéndole cierta chicha y haciendo delante della un fuego en el cual fuego le ofrezcan algún maiz y coca y sebo y cuando ansi allí fueren lleven los parientes deste novel que casi querían imitar a padrinos unas alabardas grandes y altas de oro y plata y siendo ya el sacrificio..." (p. 58)

\begin{tabular}{|c|c|c|c|c|c|c|}
\hline Meio de Troca & $\begin{array}{c}\text { Meio de } \\
\text { Pagamento }\end{array}$ & $\begin{array}{c}\text { Medida de } \\
\text { Valor }\end{array}$ & Entesouramento & Reciprocidade & $\begin{array}{c}\text { Mágico- } \\
\text { Religioso }\end{array}$ & $\begin{array}{c}\text { Objeto de } \\
\text { Prestígio }\end{array}$ \\
\hline & & & & & $\mathrm{x}$ & \\
\hline
\end{tabular}

\section{Ficha $N^{\circ} 34$}

Autor: Betanzos

\section{Objeto(s): coca}

"...ofrezcan a esta guaca y al sol estas ovejas y corderos degollándolos primero con la sangre de los cuales les sea hecha una raya con mucha reverencia por los rostros que les tome de oreja y ofrezcan ansimismo en este fuego mucha maíz y coca todo lo cual sea hecho con gran reverencia y acatamiento..." (p. 59)

\begin{tabular}{|c|c|c|c|c|c|c|}
\hline Meio de Troca & $\begin{array}{c}\text { Meio de } \\
\text { Pagamento }\end{array}$ & $\begin{array}{c}\text { Medida de } \\
\text { Valor }\end{array}$ & Entesouramento & Reciprocidade & $\begin{array}{c}\text { Mágico- } \\
\text { Religioso }\end{array}$ & $\begin{array}{c}\text { Objeto de } \\
\text { Prestígio }\end{array}$ \\
\hline & & & & & $\mathrm{x}$ & \\
\hline
\end{tabular}

\section{Ficha $N^{\circ} 35$}

Autor: Betanzos

\section{Objeto(s): coca}

"...y en este sacrificio mandó que se ofresciese mucha ropa y ovejas y coca y que de todas cuantas hierbas y plantas que había en los campos..." (p. 62)

\begin{tabular}{|c|c|c|c|c|c|c|}
\hline Meio de Troca & $\begin{array}{c}\text { Meio de } \\
\text { Pagamento }\end{array}$ & $\begin{array}{c}\text { Medida de } \\
\text { Valor }\end{array}$ & Entesouramento & Reciprocidade & $\begin{array}{c}\text { Mágico- } \\
\text { Religioso }\end{array}$ & $\begin{array}{c}\text { Objeto de } \\
\text { Prestígio }\end{array}$ \\
\hline & & & & & $\mathrm{x}$ & \\
\hline
\end{tabular}




\section{Ficha $\mathrm{N}^{\circ} 36$}

Autor: Betanzos

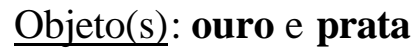

"...en la cual fiesta mandó que se hiciesen grandes sacrificios a los ídolos y se les quemase y sacrificase mucho ganado y comidas y ropa y en las tales guacas fuesen ofrecidas muchas joyas de oro y plata..." (p. 62)

\begin{tabular}{|c|c|c|c|c|c|c|}
\hline Meio de Troca & $\begin{array}{c}\text { Meio de } \\
\text { Pagamento }\end{array}$ & $\begin{array}{c}\text { Medida de } \\
\text { Valor }\end{array}$ & Entesouramento & Reciprocidade & $\begin{array}{c}\text { Mágico- } \\
\text { Religioso }\end{array}$ & $\begin{array}{c}\text { Objeto de } \\
\text { Prestígio }\end{array}$ \\
\hline & & & & & $\mathrm{x}$ & \\
\hline
\end{tabular}

\section{Ficha $\mathrm{N}^{\circ} 37$}

Autor: Betanzos

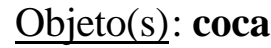

"...y que luego tras esto lanzasen en el río las flores que ya habeis oído y tras esto mandó que echasen en la agua mucha coca molida y desmenuzada..." (p. 62)

\begin{tabular}{|c|c|c|c|c|c|c|}
\hline Meio de Troca & $\begin{array}{c}\text { Meio de } \\
\text { Pagamento }\end{array}$ & $\begin{array}{c}\text { Medida de } \\
\text { Valor }\end{array}$ & Entesouramento & Reciprocidade & $\begin{array}{c}\text { Mágico- } \\
\text { Religioso }\end{array}$ & $\begin{array}{c}\text { Objeto de } \\
\text { Prestígio }\end{array}$ \\
\hline & & & & & $\mathrm{x}$ & \\
\hline
\end{tabular}

Ficha $\mathrm{N}^{\circ} 38$

Autor: Betanzos

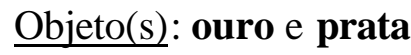

"...hacer estos sacrificios lo tienen por mal agüero ansi mismo fueron sacrificados en este sacrificio muchos niños y niñas de los cuales enterraban vivos muy bien vestidos y aderezados los cuales enterraban de dos en dos macho y hembra en cada dos destos enterraban servicio de oro y plata como eran platos escudillas y cántaron ollas y vasos para beber con todos los demás menesteres que un indio casado suele tener todo lo cual era de oro y plata e ansi enterraban estos niños con todos estos ajuares los cuales eran hijos de caciques y principales y mientras estos sacrificios se hacían todos los de la ciudad estaban en grandes fiestas y regocijos en la plaza de la ciudad..." (págs. 72-73)

\begin{tabular}{|c|c|c|c|c|c|c|}
\hline Meio de Troca & $\begin{array}{c}\text { Meio de } \\
\text { Pagamento }\end{array}$ & $\begin{array}{c}\text { Medida de } \\
\text { Valor }\end{array}$ & Entesouramento & Reciprocidade & $\begin{array}{c}\text { Mágico- } \\
\text { Religioso }\end{array}$ & $\begin{array}{c}\text { Objeto de } \\
\text { Prestígio }\end{array}$ \\
\hline & & & & & $\mathrm{x}$ & $\mathrm{x}$ \\
\hline
\end{tabular}




\section{Ficha $\mathrm{N}^{\circ} 39$}

Autor: Betanzos

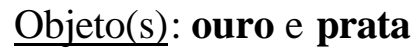

"...sacrificio y el sol la dió y su mayordomo en su nombre otras cincuenta mamaconas y salida de allí y siendo ya en las casas del Ynga los señores de la ciudad la fueron a ofrescer sus dones los cuales le ofrescieron mucho servicio de oro y plata como son cántaros de oro y de plata pequeños y grandes y platos y escudillas e ollas y vasos para su beber y mucho servicio de anaconas que pasaron de más de doscientos y esto ansi hecho y siendo las fiestas acabadas Viracocha Ynga dijo a su hijo que ya era tiempo de volver a su pueblo porque en las fiestas y regocijos que se habían hecho habían tardado tres meses en el cual tiempo él había estado siempre allí el Pachacuti le dijo que se fuese cada y cuando que quisiese y siendo proveído por Ynga Yupangue de todo lo necesario ansi bastimentos como de todo lo demás de que él tuviese necesidad en su pueblo se partió Viracocha Ynga al cual rogó Ynga Yupangue que siempre que hubiese fiestas en el Cuzco (p. 73)

\begin{tabular}{|c|c|c|c|c|c|c|}
\hline Meio de Troca & $\begin{array}{c}\text { Meio de } \\
\text { Pagamento }\end{array}$ & $\begin{array}{c}\text { Medida de } \\
\text { Valor }\end{array}$ & Entesouramento & Reciprocidade & $\begin{array}{c}\text { Mágico- } \\
\text { Religioso }\end{array}$ & $\begin{array}{c}\text { Objeto de } \\
\text { Prestígio }\end{array}$ \\
\hline & & & & & $\mathrm{x}$ & \\
\hline
\end{tabular}

\section{$\underline{\text { Ficha } N^{\circ} 40}$}

Autor: Betanzos

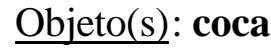

"...a los demás caciques bien ansi como si fuera vivo delante del cual bulto hacía sacrificar y quemar muchas ovejas y corderos y ropa y maiz y coca y derramar mucha chicha diciendo que el tal bulto comía y que era hijo del sol y que estaba con él en el cielo y hizo hacer muy muchos bultos y tantos cuantos señores habían sucedido desde Mango Capac hasta su padre Viracocha Ynga..." (p. 74)

\begin{tabular}{|c|c|c|c|c|c|c|}
\hline Meio de Troca & $\begin{array}{c}\text { Meio de } \\
\text { Pagamento }\end{array}$ & $\begin{array}{c}\text { Medida de } \\
\text { Valor }\end{array}$ & Entesouramento & Reciprocidade & $\begin{array}{c}\text { Mágico- } \\
\text { Religioso }\end{array}$ & $\begin{array}{c}\text { Objeto de } \\
\text { Prestígio }\end{array}$ \\
\hline & & & & & $\mathrm{x}$ & \\
\hline
\end{tabular}

\section{Ficha $\mathrm{N}^{\circ} 41$}

Autor: Betanzos

\section{Objeto(s): ouro}

"...Pachacuti Ynga Yupangu se quedó en la ciudad con los suyos en el cual dicho tiempo de los tres meses no hizo otra cosa sino holgarse él y los suyos e hacer grandes sacrificios al sol y 
a los demás ídolos e guacas haciendo muchos e grandes sacrificios en los cuales sacrificios hizo un ídolo pequeño que un hombre lo llevase en las manos sin pena el cual ídolo era de oro hecho para en que ellos adorasen mediante que la guerra durase y ellos en ella anduviesen al cual ídolo adoraban como al Dios de las batallas..." (p. 76)

\begin{tabular}{|c|c|c|c|c|c|c|}
\hline Meio de Troca & $\begin{array}{c}\text { Meio de } \\
\text { Pagamento }\end{array}$ & $\begin{array}{c}\text { Medida de } \\
\text { Valor }\end{array}$ & Entesouramento & Reciprocidade & $\begin{array}{c}\text { Mágico- } \\
\text { Religioso }\end{array}$ & $\begin{array}{c}\text { Objeto de } \\
\text { Prestígio }\end{array}$ \\
\hline & & & & & $\mathrm{x}$ & \\
\hline
\end{tabular}

\section{$\underline{\text { Ficha } \mathrm{N}^{\circ} 42}$}

Autor: Betanzos

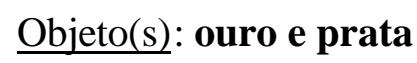

"...y tributaban y siendo allí mandó traer muchos cordeles de lana de diversos colores e tomando cada cacique por sí delante de aquellos señores del Cuzco e haciendo nudos en aquellos cordeles dió y señaló a cada uno dellos memoria de lo que ansi había de traer e tributar a él y a la ciudad de Cuzco y a unos mandó que tributasen maíz y otros ovejas y otros ropa y otros oro y otros plata e ansi de las demás cosas dando e señalando a cada uno tributos moderados..." (p. 84)

\begin{tabular}{|c|c|c|c|c|c|c|}
\hline Meio de Troca & $\begin{array}{c}\text { Meio de } \\
\text { Pagamento }\end{array}$ & $\begin{array}{c}\text { Medida de } \\
\text { Valor }\end{array}$ & Entesouramento & Reciprocidade & $\begin{array}{c}\text { Mágico- } \\
\text { Religioso }\end{array}$ & $\begin{array}{c}\text { Objeto de } \\
\text { Prestígio }\end{array}$ \\
\hline & $\mathrm{x}$ & & & & & \\
\hline
\end{tabular}

\section{Ficha $N^{\circ} 43$}

Autor: Betanzos

Objeto(s): ouro e prata

"...meses a la ciudad del Cuzco las comidas que ansi les era mandado que trujesen para proveimiento de la ciudad y que ansi mismo tuviesen cuidado de mandar hacer traer la ropa y oro y plata y ganados y las demás cosas que habían de traer cada año de tributo..." (p. 84)

\begin{tabular}{|c|c|c|c|c|c|c|}
\hline Meio de Troca & $\begin{array}{c}\text { Meio de } \\
\text { Pagamento }\end{array}$ & $\begin{array}{c}\text { Medida de } \\
\text { Valor }\end{array}$ & Entesouramento & Reciprocidade & $\begin{array}{c}\text { Mágico- } \\
\text { Religioso }\end{array}$ & $\begin{array}{c}\text { Objeto de } \\
\text { Prestígio }\end{array}$ \\
\hline & $\mathrm{x}$ & & & & & \\
\hline
\end{tabular}

\section{Ficha $\mathrm{N}^{\circ} 44$}

Autor: Betanzos

\section{Objeto(s): ouro, prata e coca}

"...y que fuesen ansi todos juntos a sus casas y que preguntasen a las mujeres del Ynga que cuál quería ir con él y lo mismo a sus hijos e hijas y los que quisiesen ir con él ansi mujeres 
como hombres que los vistiesen de ropa y preciada y de joyas de oro y plata según su traje y que estos que ansi habían de ir con él bailasen y cantasen y hiciesen gran fiesta aquel día y bebiesen mucha chicha y en tanta cantidad que se embriagasen y siendo embriagados ansi hombres como mujeres los ahogasen y con todas sus joyas ansi como estaban llevando cada uno dellos las cosas que les servían los enterrasen y habran de saber que las cosas que ansi llevaban estos muertos las mujeres llevaban joyas y cántaros pequeños llenos de chicha y bolsa con coca y maíz tostado y cocido en las ollas y potajes hechos y platos y escudillas y jarros y vasos de servicios todo lo cual era de oro y plata y los hombres llevaban según los cargos que en su casa tenían hasta el portero como quisiese ir con su señor era enterrado a la puerta de su sepultura y ansi todos estos muertos y ahogados eran enterrados con las cosas ya dichas y en la manera ya dicha y mandó que esto hecho que todos los señores del Cuzco se saliesen a la plaza y allí le llorasen..." (p. 118)

\begin{tabular}{|c|c|c|c|c|c|c|}
\hline Meio de Troca & $\begin{array}{c}\text { Meio de } \\
\text { Pagamento }\end{array}$ & $\begin{array}{c}\text { Medida de } \\
\text { Valor }\end{array}$ & Entesouramento & Reciprocidade & $\begin{array}{c}\text { Mágico- } \\
\text { Religioso }\end{array}$ & $\begin{array}{c}\text { Objeto de } \\
\text { Prestígio }\end{array}$ \\
\hline & & & & & $\mathrm{x}$ & $\mathrm{x}$ \\
\hline
\end{tabular}

OBS:. Neste caso, a coca refere-se apenas ao contexto mágico-religioso.

\section{Ficha $\mathrm{N}^{\circ} 45$}

Autor: Betanzos

\section{Objeto(s): ouro}

"...vestido y encima de su sepulcro mandó Ynga Yupangue que fuese puesto un bulto de oro hecho a su semejanza y en su lugar a quien las gentes que allí fuesen adorasen en su nombre y luego fue puesto y de las uñas y cabellos que en su vida se cortaba mandó que fuese hecho un bulto el cual ansi fue hecho..." (p. 122)

\begin{tabular}{|c|c|c|c|c|c|c|}
\hline Meio de Troca & $\begin{array}{c}\text { Meio de } \\
\text { Pagamento }\end{array}$ & $\begin{array}{c}\text { Medida de } \\
\text { Valor }\end{array}$ & Entesouramento & Reciprocidade & $\begin{array}{c}\text { Mágico- } \\
\text { Religioso }\end{array}$ & $\begin{array}{c}\text { Objeto de } \\
\text { Prestígio }\end{array}$ \\
\hline & & & & & $\mathrm{x}$ & \\
\hline
\end{tabular}

\section{$\underline{\text { Ficha } \mathrm{N}^{\circ} 46}$}

Autor: Betanzos

\section{Objeto(s): ouro}

"...y que sería bien dejar en la tal provincia guarnición de gente de guerra para que lo que ansi había ganado y consquistado lo tuviese quieto y pacífico y desde allí le llevasen su tributo de oro a la ciudad del Cuzco..." (p. 131) 


\begin{tabular}{|c|c|c|c|c|c|c|}
\hline Meio de Troca & $\begin{array}{c}\text { Meio de } \\
\text { Pagamento }\end{array}$ & $\begin{array}{c}\text { Medida de } \\
\text { Valor }\end{array}$ & Entesouramento & Reciprocidade & $\begin{array}{c}\text { Mágico- } \\
\text { Religioso }\end{array}$ & $\begin{array}{c}\text { Objeto de } \\
\text { Prestígio }\end{array}$ \\
\hline & $\mathrm{x}$ & & & & & \\
\hline
\end{tabular}

Ficha $\mathrm{N}^{\circ} 47$

Autor: Betanzos

Objeto(s): ouro

"...que había de ser enterrado e ansi mismo halló los de su casa que hacían el sentimiento e ayuno según que había quedado ordenado por su padre y siendo el tiempo llegado de su enterramiento le hizo enterrar según que el cuerpo de su padre e ansí mesmo le hizo hacer un bulto de oro el cual se puso encima de su sepulcro al cual bulto de oro el mismo por sus manos le puso una borla encima de su cabeza según que la que él traía en la suya y de sus uñas y cabellos hizo que le hiciesen un bulto según que el de su padre a quien la gente reverenciase porque habrán de saber que mientras estos señores vivían eran acatados y reverenciados como a hijos del sol y después de muertos sus bultos eran acatados..." (p. 135)

\begin{tabular}{|c|c|c|c|c|c|c|}
\hline Meio de Troca & $\begin{array}{c}\text { Meio de } \\
\text { Pagamento }\end{array}$ & $\begin{array}{c}\text { Medida de } \\
\text { Valor }\end{array}$ & Entesouramento & Reciprocidade & $\begin{array}{c}\text { Mágico- } \\
\text { Religioso }\end{array}$ & $\begin{array}{c}\text { Objeto de } \\
\text { Prestígio }\end{array}$ \\
\hline & & & & & $\mathrm{x}$ & \\
\hline
\end{tabular}

$\underline{\text { Ficha } N^{\circ} 48}$

Autor: Betanzos

\section{Objeto(s): ouro e prata}

"...y guardando en todo y por todos los mandamientos y cosas ordenadas por su padre ansi mismo entendía en enviar muchas cosas y dádivas a los señores caciques naturales de toda la tierra enviando a unos ropa preciada y a otros mujeres de la nación del Cuzco en quien viniesen sus descendientes y sus sucesores y a otros vasos y joyas de oro y plata según que a él mejor le parescía todo lo cual hacía Topa Ynga Yupangue por tenerlos y conservarlos en su amistad porque no se le rebelasen y le inquietasen..." (p. 139)

\begin{tabular}{|c|c|c|c|c|c|c|}
\hline Meio de Troca & $\begin{array}{c}\text { Meio de } \\
\text { Pagamento }\end{array}$ & $\begin{array}{c}\text { Medida de } \\
\text { Valor }\end{array}$ & Entesouramento & Reciprocidade & $\begin{array}{c}\text { Mágico- } \\
\text { Religioso }\end{array}$ & $\begin{array}{c}\text { Objeto de } \\
\text { Prestígio }\end{array}$ \\
\hline & & & & $\mathrm{x}$ & & $\mathrm{x}$ \\
\hline
\end{tabular}

$\underline{\text { Ficha } N^{\circ} 49}$

Autor: Betanzos

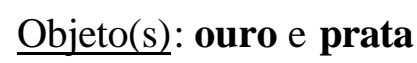


"...Guayna Capac juntamente con los gobernadores entendieron en mirar las cosas de su ciudad y república della todo lo cual hecho y acabado de proveer ansi por los visitadores que a las provincias fueron como por Guayna Capac y los gobernadores ya que fueron vueltos los señores visitadores Guayna Capac y los gobernadores ordenaron de enviar grandes dones y dádivas de ropa ovejas vasos de oro y plata y mujeres de la nación del Cuzco a todos los caciques señores de toda la tierra y como ansi lo ordenasen luego lo pusieron por obra y enviaron lo cual ordenaron e hicieron por conservar sus vasallos y súbditos en su amistad y amor y tenerlos siempre en contentamiento lo cual siempre hicieron los gobernadores por tenerlos quietos y pacíficos todo el tiempo que ellos gobernasen..." (p. 142)

\begin{tabular}{|c|c|c|c|c|c|c|}
\hline Meio de Troca & $\begin{array}{c}\text { Meio de } \\
\text { Pagamento }\end{array}$ & $\begin{array}{c}\text { Medida de } \\
\text { Valor }\end{array}$ & Entesouramento & Reciprocidade & $\begin{array}{c}\text { Mágico- } \\
\text { Religioso }\end{array}$ & $\begin{array}{c}\text { Objeto de } \\
\text { Prestígio }\end{array}$ \\
\hline & & & & $\mathrm{x}$ & & \\
\hline
\end{tabular}

Ficha $\mathrm{N}^{\circ} 50$

Autor: Betanzos

Objeto(s): coca e ají

"...y de allí mandó a los señores del Cuzco que hiciesen los llantos acostumbrados y sacrificios y pasados seis meses después de la muerte de esta señora hizo llamar Guayna Capac secretamente a los señores del Cuzco y díjoles que quería ir a comprar coca y ají a la provincia de Chinchasuyo para de vuelta hacer la fiesta de Purucaya..."(p. 147)

\begin{tabular}{|c|c|c|c|c|c|c|}
\hline Meio de Troca & $\begin{array}{c}\text { Meio de } \\
\text { Pagamento }\end{array}$ & $\begin{array}{c}\text { Medida de } \\
\text { Valor }\end{array}$ & Entesouramento & Reciprocidade & $\begin{array}{c}\text { Mágico- } \\
\text { Religioso }\end{array}$ & $\begin{array}{c}\text { Objeto de } \\
\text { Prestígio }\end{array}$ \\
\hline & & & & & $\mathrm{x}$ & \\
\hline
\end{tabular}

\section{$\underline{\text { Ficha } \mathrm{N}^{\circ} 51}$}

Autor: Betanzos

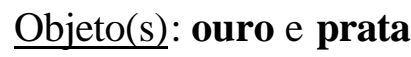

"... y de allí partió a matalle una suntuosa guaca que quiere decir guaca adoratorio ídolo en la cual guaca ofrecieron mucha cantidad de oro y plata a estos y sus descendientes..."

\begin{tabular}{|c|c|c|c|c|c|c|}
\hline Meio de Troca & $\begin{array}{c}\text { Meio de } \\
\text { Pagamento }\end{array}$ & $\begin{array}{c}\text { Medida de } \\
\text { Valor }\end{array}$ & Entesouramento & Reciprocidade & $\begin{array}{c}\text { Mágico- } \\
\text { Religioso }\end{array}$ & $\begin{array}{c}\text { Objeto de } \\
\text { Prestígio }\end{array}$ \\
\hline & & & & & $\mathrm{x}$ & \\
\hline
\end{tabular}

$\underline{\text { Ficha } \mathrm{N}^{\circ} 52}$

Autor: Betanzos

Objeto(s): ouro 
"...y porque este viracocha allí se hubiese sentado le hicieron en aquel lugar una muy rica y suntuosa guaca en la cual guaca porque se sentó en aquel lugar este viracocha pusieron los que la edificaron un escaño de oro fino y el bulto que en lugar deste viracocha pusieron le asentaron en este escaño el cual valió de fino oro en las partes del Cuzco que los xipianos se hicieron cuando le ganaron diez y seis o diez y ocho mil pesos y de allí el viracocha se pertió..."

\begin{tabular}{|c|c|c|c|c|c|c|}
\hline Meio de Troca & $\begin{array}{c}\text { Meio de } \\
\text { Pagamento }\end{array}$ & $\begin{array}{c}\text { Medida de } \\
\text { Valor }\end{array}$ & Entesouramento & Reciprocidade & $\begin{array}{c}\text { Mágico- } \\
\text { Religioso }\end{array}$ & $\begin{array}{c}\text { Objeto de } \\
\text { Prestígio }\end{array}$ \\
\hline & & & & & $\mathrm{x}$ & \\
\hline
\end{tabular}

\section{Ficha $N^{\circ} 53$}

Autor: Vaca de Castro

\section{Objeto(s): coca, ají, conchas}

"Outro si porque es justo que los Indios que llevarem las cargas de los Españoles caminantes lleben alguna gratificacion y visto que en oro, ni en plata no se podria hacer por no haber moneda en estos Reynos ni convenir que se haga Mando que sean pagados en coca que ellos tienen por cosa de mas calidad que oro, ni plata, o en agi, o en chaquira de España que ellos tienen en mucho, o si fuera en coca o agi se de un puñado a cada Indio de carga..." (p. 469)

\begin{tabular}{|c|c|c|c|c|c|c|}
\hline Meio de Troca & $\begin{array}{c}\text { Meio de } \\
\text { Pagamento }\end{array}$ & $\begin{array}{c}\text { Medida de } \\
\text { Valor }\end{array}$ & Entesouramento & Reciprocidade & $\begin{array}{c}\text { Mágico- } \\
\text { Religioso }\end{array}$ & $\begin{array}{c}\text { Objeto de } \\
\text { Prestígio }\end{array}$ \\
\hline & $\mathrm{x}$ & & & & & \\
\hline
\end{tabular}

\section{Ficha $\mathrm{N}^{\circ} 54$}

Autor: Anônimo

\section{Objeto(s): coca, ají}

"Los Indios Yungas, mandaron los visitadores que pagasen de tributo ropa, algodón, coca, agí, pescado y otras cosas de frutas secas, todo en poca cantidad porque no tenían minas de oro y plata en su tierra..." (págs. 170-171)

\begin{tabular}{|c|c|c|c|c|c|c|}
\hline Meio de Troca & $\begin{array}{c}\text { Meio de } \\
\text { Pagamento }\end{array}$ & $\begin{array}{c}\text { Medida de } \\
\text { Valor }\end{array}$ & Entesouramento & Reciprocidade & $\begin{array}{c}\text { Mágico- } \\
\text { Religioso }\end{array}$ & $\begin{array}{c}\text { Objeto de } \\
\text { Prestígio }\end{array}$ \\
\hline & $\mathrm{x}$ & & & & & \\
\hline
\end{tabular}

$\underline{\text { Ficha } \mathrm{N}^{\circ} 55}$

Autor: Anônimo

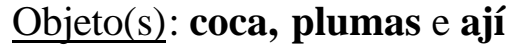


"A los Indios de andesuyu que es la montaña adelante donde sacaban la coca, no pagaban de tributo sino plumas de páxaros y algunos monos, y otros pagaban algún poco de coca y algún agí y dardos de palmas". (p. 170)

\begin{tabular}{|c|c|c|c|c|c|c|}
\hline Meio de Troca & $\begin{array}{c}\text { Meio de } \\
\text { Pagamento }\end{array}$ & $\begin{array}{c}\text { Medida de } \\
\text { Valor }\end{array}$ & Entesouramento & Reciprocidade & $\begin{array}{c}\text { Mágico- } \\
\text { Religioso }\end{array}$ & $\begin{array}{c}\text { Objeto de } \\
\text { Prestígio }\end{array}$ \\
\hline & $\mathrm{x}$ & & & & & \\
\hline
\end{tabular}

\section{Ficha $\mathrm{N}^{\circ} 56$}

Autor: Anônimo

\section{Objeto(s): cobre, ouro e prata}

"Era la gente de Chincha muy atrevida y de mucha razón y policía, porque podemos decir que sólo ellos en este Reyno trataban con moneda, porque entre ellos compraban y véndian con cobre lo que avían de comer y vestir, y tenían puesto lo [que] valía cada marco de cobre; y demás de esto estimaban cada peso de oro en más de diez veces el peso de plata y tenían sus pesos y pesas con que pesaban oro y plata y sus toques con sus puntas..." (p. 171)

\begin{tabular}{|c|c|c|c|c|c|c|}
\hline Meio de Troca & $\begin{array}{c}\text { Meio de } \\
\text { Pagamento }\end{array}$ & $\begin{array}{c}\text { Medida de } \\
\text { Valor }\end{array}$ & Entesouramento & Reciprocidade & $\begin{array}{c}\text { Mágico- } \\
\text { Religioso }\end{array}$ & $\begin{array}{c}\text { Objeto de } \\
\text { Prestígio }\end{array}$ \\
\hline $\mathrm{x}$ & $\mathrm{x}$ & $\mathrm{x}$ & & & & \\
\hline
\end{tabular}

OBS:. Neste caso, ouro e prata referem-se apenas ao contexto de medida de valor.

\section{Ficha $\mathrm{N}^{\circ} 57$}

\section{Autor: Garci Diez}

\section{Objeto(s): coca}

"...y que en Moquegua en los yungas le dan doce indios que le siembram y benefician nueve topos de tierra de maíz y que les da aquellos indios carneros y costales para traer estiércol para el beneficio de maíz porque no se coge de outra manera y les da para ellos coca y ovejas y lana para que se vistan y charqui para que coman ...y que en los yungas de Chicanoma le dan otros dos indios los cuales le cogen allí cada año tres o cuatro cestos de coca y les da de comer como a los demás y de la dicha coca que sacan toman los indios la mitad para sí." (p. 33)

\begin{tabular}{|c|c|c|c|c|c|c|}
\hline Meio de Troca & $\begin{array}{c}\text { Meio de } \\
\text { Pagamento }\end{array}$ & $\begin{array}{c}\text { Medida de } \\
\text { Valor }\end{array}$ & Entesouramento & Reciprocidade & $\begin{array}{c}\text { Mágico- } \\
\text { Religioso }\end{array}$ & $\begin{array}{c}\text { Objeto de } \\
\text { Prestígio }\end{array}$ \\
\hline & $\mathrm{x}$ & & & & & \\
\hline
\end{tabular}




\section{Ficha $\mathrm{N}^{\circ} 58$}

\section{Autor: Garci Diez}

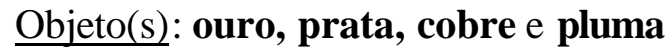

"Preguntando qué tributo daban al ynga en su tiempo y en qué cosas dijo que le daban tres mil indios para la guerra algunas veces otras veces le daban todos los indios que querían para hacer paredes y casas y para su servicio y hijos para sacrificar y doncellas para que le sirviesen y para el Sol y la Luna y los truenos y ropa y le hacían muchas chácaras y le daban oro y plata que sacaban el oro de Chuquiabo y la plata de las minas de Porco y asímismo le daban plomo de tributo y un barniz colorado que llaman limpi y cobre y plumas y todo lo que él queria pedir le daban como a su señor..." (p. 39)

\begin{tabular}{|c|c|c|c|c|c|c|}
\hline Meio de Troca & $\begin{array}{c}\text { Meio de } \\
\text { Pagamento }\end{array}$ & $\begin{array}{c}\text { Medida de } \\
\text { Valor }\end{array}$ & Entesouramento & Reciprocidade & $\begin{array}{c}\text { Mágico- } \\
\text { Religioso }\end{array}$ & $\begin{array}{c}\text { Objeto de } \\
\text { Prestígio }\end{array}$ \\
\hline & $\mathrm{x}$ & & & & & \\
\hline
\end{tabular}

$\underline{\text { Ficha } \mathrm{N}^{\circ} 59}$

Autor: Garci Diez

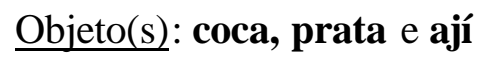

"...la principal hacienda granjería que tienen es mucho ganado de la tierra y que sacan lana de ello y la venden muy bien vendida y rescatan muchos carneros por coca y plata y van con su ganado a los yungas a cargar de maíz y ají y otras cosas y alquilan ellos con españoles a cargar coca de aquí al Cuzco y del Cuzco a Potosi y se alquilan para el puerto de Ilo y Arequipa para sacar merdaderías y hacen mucha cantidad de ropa de la tierra a españoles que les valen mucho dinero..." (p. 54)

\begin{tabular}{|c|c|c|c|c|c|c|}
\hline Meio de Troca & $\begin{array}{c}\text { Meio de } \\
\text { Pagamento }\end{array}$ & $\begin{array}{c}\text { Medida de } \\
\text { Valor }\end{array}$ & Entesouramento & Reciprocidade & $\begin{array}{c}\text { Mágico- } \\
\text { Religioso }\end{array}$ & $\begin{array}{c}\text { Objeto de } \\
\text { Prestígio }\end{array}$ \\
\hline $\mathrm{x}$ & $\mathrm{x}$ & & & & & \\
\hline
\end{tabular}

Ficha $N^{\circ} 60$

Autor: Garci Diez

\section{Objeto(s): conchas}

"Fueron preguntados de qué edad tributaban los indios en tiempo del ynga dijeron que tributaban desde que tomaban mujer y tenían chácara y hacían cada hasta que eran viejos y que los muchachos de diez años arriba le traían al ynga pájaros y caracoles y leña y paja y le iban bailanado delante de él." (p. 94) 


\begin{tabular}{|c|c|c|c|c|c|c|}
\hline Meio de Troca & $\begin{array}{c}\text { Meio de } \\
\text { Pagamento }\end{array}$ & $\begin{array}{c}\text { Medida de } \\
\text { Valor }\end{array}$ & Entesouramento & Reciprocidade & $\begin{array}{c}\text { Mágico- } \\
\text { Religioso }\end{array}$ & $\begin{array}{c}\text { Objeto de } \\
\text { Prestígio }\end{array}$ \\
\hline & $\mathrm{x}$ & & & & & \\
\hline
\end{tabular}

Ficha $\mathrm{N}^{\circ} 61$

Autor: Garci Diez

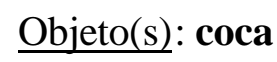

"...y que a unos les dan medio tomín cada día los españoles y a otros un poco de coca y a otros no les dan nada y que en el tiempo que están ocupados en Chucuito dejan de entender en sus haciendas." (p. 96)

\begin{tabular}{|l|l|l|l|l|l|l|}
\hline Meio de Troca & $\begin{array}{l}\text { Meio de } \\
\text { Pagamento }\end{array}$ & $\begin{array}{l}\text { Medida de } \\
\text { Valor }\end{array}$ & Entesouramento & Reciprocidade & $\begin{array}{l}\text { Mágico- } \\
\text { Religioso }\end{array}$ & $\begin{array}{l}\text { Objeto de } \\
\text { Prestígio }\end{array}$ \\
\hline & $\mathrm{x}$ & & & & & \\
\hline
\end{tabular}

Ficha $\mathrm{N}^{\circ} 62$

Autor: Garci Diez

\section{Objeto(s): plumas}

"...y que de toda la provincia le daban unas veces cien indios e indias de servicio y otras doscientas y que le daban indios por sus mitas para que le hiciesen casas en el Cuzco y que a los caciques que los enviaban les daba el ynga mantas y camisetas de las ricas y a los indios que trabajan les daba de comer carne y maíz y chicha y otras cosas y los trataba muy bien y asimismo le daban indios para sacrificar a las guacas y hijas de los caciques...y todo lo demás que les pedía se lo daban hasta sal y plumas y que todo esto que tiene declarado se lo daban entre toda la provincia repartido por ayllos." (p. 106)

\begin{tabular}{|c|c|c|c|c|c|c|}
\hline Meio de Troca & $\begin{array}{c}\text { Meio de } \\
\text { Pagamento }\end{array}$ & $\begin{array}{c}\text { Medida de } \\
\text { Valor }\end{array}$ & Entesouramento & Reciprocidade & $\begin{array}{c}\text { Mágico- } \\
\text { Religioso }\end{array}$ & $\begin{array}{c}\text { Objeto de } \\
\text { Prestígio }\end{array}$ \\
\hline & $\mathrm{x}$ & & & & & \\
\hline
\end{tabular}

\section{Ficha $\mathrm{N}^{\circ} 63$}

\section{Autor: Garci Diez}

\section{Objeto(s): coca}

"...y que no les dan ropa ni outra cosa alguna más de lo que tienen declarado y que podría ser que los cumbicamayos les hiciese algunas piezas de ropa para su vestir y que a los cumbicamayos les dan coca y corderos por este trabajo." (p. 117)

\begin{tabular}{|c|c|c|c|c|c|c|}
\hline Meio de Troca & $\begin{array}{c}\text { Meio de } \\
\text { Pagamento }\end{array}$ & $\begin{array}{c}\text { Medida de } \\
\text { Valor }\end{array}$ & Entesouramento & Reciprocidade & $\begin{array}{c}\text { Mágico- } \\
\text { Religioso }\end{array}$ & $\begin{array}{c}\text { Objeto de } \\
\text { Prestígio }\end{array}$ \\
\hline & $\mathrm{x}$ & & & & & \\
\hline
\end{tabular}




\section{Ficha $\mathrm{N}^{\circ} 64$}

Autor: Garci Diez

\section{Objeto(s): coca}

"...y que a los indios que les sierven les dan de comer y coca y alguna lana de que hagan vestidos para ellos y cuando los envían camino se lo pagan el cual dicho tributo le dan los indios de su parcialidad." (p. 120)

\begin{tabular}{|c|c|c|c|c|c|c|}
\hline Meio de Troca & $\begin{array}{c}\text { Meio de } \\
\text { Pagamento }\end{array}$ & $\begin{array}{c}\text { Medida de } \\
\text { Valor }\end{array}$ & Entesouramento & Reciprocidade & $\begin{array}{c}\text { Mágico- } \\
\text { Religioso }\end{array}$ & $\begin{array}{c}\text { Objeto de } \\
\text { Prestígio }\end{array}$ \\
\hline & $\mathrm{x}$ & & & & & \\
\hline
\end{tabular}

$\underline{\text { Ficha } N^{\circ} 65}$

Autor: Garci Diez

\section{Objeto(s): ají}

"...y lo demás para aprovecharse ellos y que con el maiz y ají rescatan ganado de la tierra que les traen los indios serranos y lana y ropa y plata que les dan por el maiz y trigo y ají que venden..." (p. 124)

\begin{tabular}{|c|c|c|c|c|c|c|}
\hline Meio de Troca & $\begin{array}{c}\text { Meio de } \\
\text { Pagamento }\end{array}$ & $\begin{array}{c}\text { Medida de } \\
\text { Valor }\end{array}$ & Entesouramento & Reciprocidade & $\begin{array}{c}\text { Mágico- } \\
\text { Religioso }\end{array}$ & $\begin{array}{c}\text { Objeto de } \\
\text { Prestígio }\end{array}$ \\
\hline $\mathrm{x}$ & $\mathrm{x}$ & & & & & \\
\hline
\end{tabular}

Ficha $N^{\circ} 66$

Autor: Garci Diez

Objeto(s): coca

"...y que ningunas sementeras se hacen en la provincia que no sean los primeros a trabajar o en la de los caciques y en éstas siempre o en las de otros indios que les dan coca y de beber u outro género de paga..." (p. 140)

\begin{tabular}{|c|c|c|c|c|c|c|}
\hline Meio de Troca & $\begin{array}{c}\text { Meio de } \\
\text { Pagamento }\end{array}$ & $\begin{array}{c}\text { Medida de } \\
\text { Valor }\end{array}$ & Entesouramento & Reciprocidade & $\begin{array}{c}\text { Mágico- } \\
\text { Religioso }\end{array}$ & $\begin{array}{c}\text { Objeto de } \\
\text { Prestígio }\end{array}$ \\
\hline & $\mathrm{x}$ & & & & & \\
\hline
\end{tabular}

\section{Ficha $\mathrm{N}^{\circ} 67$}

\section{Autor: Garci Diez}

\section{Objeto(s): plumas}

"Los tributos que todos los indios en general declaran que daban al ynga en su tiempo eram indios para la guerra todos los que les pedía y dicen que para una guerra que hizo contra los 
de Tomebamba que es en el partido de Quito más de trescientas leguas de la dicha provincia le dieron seis mil indios y que asismismo le daban indios e indias y muchachos para su servicio y para sacar oro y plata en las minas y para que le hiciecen casas en el Cuzco y niños para sacrificar a las guacas y hijas de los caciques más principales del reino para mencebas hacíanle sementereas en sus tieras dábanle carneros y ropa y calzado y caza y plumajes y finalmente le daban todo lo que les pedía..." (p. 204)

\begin{tabular}{|c|c|c|c|c|c|c|}
\hline Meio de Troca & $\begin{array}{c}\text { Meio de } \\
\text { Pagamento }\end{array}$ & $\begin{array}{c}\text { Medida de } \\
\text { Valor }\end{array}$ & Entesouramento & Reciprocidade & $\begin{array}{c}\text { Mágico- } \\
\text { Religioso }\end{array}$ & $\begin{array}{c}\text { Objeto de } \\
\text { Prestígio }\end{array}$ \\
\hline & $\mathrm{x}$ & & & & & \\
\hline
\end{tabular}

Ficha $\mathrm{N}^{\circ} 68$

Autor: Garci Diez

Objeto(s): coca

"...ni contraten con los indios ni les den vino ni coca ni outra cosa alguna que rescatem..."

(p. 241)

\begin{tabular}{|c|c|c|c|c|c|c|}
\hline Meio de Troca & $\begin{array}{c}\text { Meio de } \\
\text { Pagamento }\end{array}$ & $\begin{array}{c}\text { Medida de } \\
\text { Valor }\end{array}$ & Entesouramento & Reciprocidade & $\begin{array}{c}\text { Mágico- } \\
\text { Religioso }\end{array}$ & $\begin{array}{c}\text { Objeto de } \\
\text { Prestígio }\end{array}$ \\
\hline $\mathrm{x}$ & $\mathrm{x}$ & & & & & \\
\hline
\end{tabular}

Ficha $\mathrm{N}^{\circ} 69$

Autor: Garci Diez

Objeto(s): coca

"El tributo que estos indios de Chiacanoma han pagado hasta ahora há sido en coca la cual han recibido y cobrado los caciques de la dicha provincia de Chucuito...y meta lo procedido del ganado de la comunidad para ayuda a pagar los tributos hecha que sea la tasa pagarán estos indios lo que les cupiere en dinero porque dándole en coca como ahora lo dan pagan mucho más de lo que les cabe." (p. 244)

\begin{tabular}{|c|c|c|c|c|c|c|}
\hline Meio de Troca & $\begin{array}{c}\text { Meio de } \\
\text { Pagamento }\end{array}$ & $\begin{array}{c}\text { Medida de } \\
\text { Valor }\end{array}$ & Entesouramento & Reciprocidade & $\begin{array}{c}\text { Mágico- } \\
\text { Religioso }\end{array}$ & $\begin{array}{c}\text { Objeto de } \\
\text { Prestígio }\end{array}$ \\
\hline & $\mathrm{x}$ & & & & & \\
\hline
\end{tabular}

Ficha $\mathrm{N}^{\circ} 70$

Autor: Garci Diez

$\underline{\text { Objeto(s): coca }}$

"Assimismo a causa de coger poca comida los dichos indios de Moquegua van a rescatarla con carne y coca y otras cosas entre los indios comarcanos y algunos encomenderos se lo 
impiden siendo una cosa muy usada en todo este Reino en el tiempo del Ynga y después acá rescatan unos indios con otros..." (p. 247)

\begin{tabular}{|c|c|c|c|c|c|c|}
\hline Meio de Troca & $\begin{array}{c}\text { Meio de } \\
\text { Pagamento }\end{array}$ & $\begin{array}{c}\text { Medida de } \\
\text { Valor }\end{array}$ & Entesouramento & Reciprocidade & $\begin{array}{c}\text { Mágico- } \\
\text { Religioso }\end{array}$ & $\begin{array}{c}\text { Objeto de } \\
\text { Prestígio }\end{array}$ \\
\hline $\mathrm{x}$ & & & & & & \\
\hline
\end{tabular}

Ficha $\mathrm{N}^{\circ} 71$

Autor: Garci Diez

Objeto(s): coca

"Gran desorden hay en la dicha provincia de Chucuito en el comprar de la coca porque como generalmente los indios aymares tienen ganado dan por un cesto de coca un carnero de la tierra que vale siete o ocho pesos y aun dineros encima..." (p. 251)

\begin{tabular}{|c|c|c|c|c|c|c|}
\hline Meio de Troca & $\begin{array}{c}\text { Meio de } \\
\text { Pagamento }\end{array}$ & $\begin{array}{c}\text { Medida de } \\
\text { Valor }\end{array}$ & Entesouramento & Reciprocidade & $\begin{array}{c}\text { Mágico- } \\
\text { Religioso }\end{array}$ & $\begin{array}{c}\text { Objeto de } \\
\text { Prestígio }\end{array}$ \\
\hline $\mathrm{x}$ & & & & & & \\
\hline
\end{tabular}

Ficha $\mathrm{N}^{\circ} 72$

Autor: Garci Diez

Objeto(s): coca

"...que a estos indios de Chicanoma se les lleve por sus caciques más tributo del que les cupiere y debieren pagar conforme a la tasa y si lo cobrasen en coca sea tasado en lo que justamente valiere y el precio por que se vendiere se junte con lo demás por el tributo de manera que los caciques no se queden con ello." (p. 267)

\begin{tabular}{|c|c|c|c|c|c|c|}
\hline Meio de Troca & $\begin{array}{c}\text { Meio de } \\
\text { Pagamento }\end{array}$ & $\begin{array}{c}\text { Medida de } \\
\text { Valor }\end{array}$ & Entesouramento & Reciprocidade & $\begin{array}{c}\text { Mágico- } \\
\text { Religioso }\end{array}$ & $\begin{array}{c}\text { Objeto de } \\
\text { Prestígio }\end{array}$ \\
\hline & $\mathrm{x}$ & & & & & \\
\hline
\end{tabular}

Ficha $\mathrm{N}^{\circ} 73$

Autor: Miguel de Estete

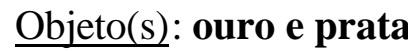

"...y al pie y a la redonda de él muchas cosillas de oro y de plata ofrendadas de muchos tiempos y soterradas por aquella tierra." (p. 283)

\begin{tabular}{|c|c|c|c|c|c|c|}
\hline Meio de Troca & $\begin{array}{c}\text { Meio de } \\
\text { Pagamento }\end{array}$ & $\begin{array}{c}\text { Medida de } \\
\text { Valor }\end{array}$ & Entesouramento & Reciprocidade & $\begin{array}{c}\text { Mágico- } \\
\text { Religioso }\end{array}$ & $\begin{array}{c}\text { Objeto de } \\
\text { Prestígio }\end{array}$ \\
\hline & & & & & $\mathrm{x}$ & \\
\hline
\end{tabular}




\section{Ficha $\mathrm{N}^{\circ} 74$}

Autor: Miguel de Estete

\section{Objeto(s): ouro e prata}

"Sabido esto por Atabalica dijo que pues el gobernador quería enviar a ver la tierra hacia el Cuzco, que poco al través del camino real estaba la gran mezquita de Pachacama, donde iban de toda la tierra a romería y era el principal santuario y adoratorio de ella; que sería bien que la fuesen a ver de camino, que en ella había mucha cantidad de oro y plata; y que allí estaba un sacerdote de ella que iría con la gente..." (p. 381)

\begin{tabular}{|c|c|c|c|c|c|c|}
\hline Meio de Troca & $\begin{array}{c}\text { Meio de } \\
\text { Pagamento }\end{array}$ & $\begin{array}{c}\text { Medida de } \\
\text { Valor }\end{array}$ & Entesouramento & Reciprocidade & $\begin{array}{c}\text { Mágico- } \\
\text { Religioso }\end{array}$ & $\begin{array}{c}\text { Objeto de } \\
\text { Prestígio }\end{array}$ \\
\hline & & & & & $\mathrm{x}$ & \\
\hline
\end{tabular}

\section{Ficha $\mathrm{N}^{\circ} 75$}

Autor: Miguel de Estete

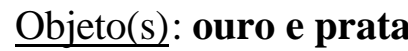

"En este tiempo, a la nueva de lo hecho y a vernos venían todos los pueblos comarcanos y traían presentes de oro y de plata. Esta mezquita estaba entre tierras muy pobladas y ricas, y así se juntó buena cantidad de oro y plata." (p. 384)

\begin{tabular}{|c|c|c|c|c|c|c|}
\hline Meio de Troca & $\begin{array}{c}\text { Meio de } \\
\text { Pagamento }\end{array}$ & $\begin{array}{c}\text { Medida de } \\
\text { Valor }\end{array}$ & Entesouramento & Reciprocidade & $\begin{array}{c}\text { Mágico- } \\
\text { Religioso }\end{array}$ & $\begin{array}{c}\text { Objeto de } \\
\text { Prestígio }\end{array}$ \\
\hline & & & & & $\mathrm{x}$ & \\
\hline
\end{tabular}

\section{Ficha $\mathrm{N}^{\circ} 76$}

\section{Autor: Miguel de Estete}

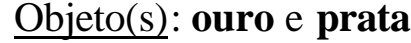

"Halláronse en ella mucha cantidad de oro y plata, aunque no de particulares, sino que se hallaba en aquellos templos y oratorios y cuevas y enterramientos donde estaba echado como cosa no tenida en mucho; y tomáronse muchas vasijas de oro y plata y entre ellas ocho trojes de plata en que tenían el trigo o maíz para el templo; creo que pesaron estas trojes, después de fundidas, veinticinco mil marcos de plata." (p. 392)

\begin{tabular}{|c|c|c|c|c|c|c|}
\hline Meio de Troca & $\begin{array}{c}\text { Meio de } \\
\text { Pagamento }\end{array}$ & $\begin{array}{c}\text { Medida de } \\
\text { Valor }\end{array}$ & Entesouramento & Reciprocidade & $\begin{array}{c}\text { Mágico- } \\
\text { Religioso }\end{array}$ & $\begin{array}{c}\text { Objeto de } \\
\text { Prestígio }\end{array}$ \\
\hline & & & & & $\mathrm{x}$ & \\
\hline
\end{tabular}




\section{$\underline{\text { Ficha } N^{\circ} 77}$}

Autor: Miguel de Estete

\section{Objeto(s): ouro e prata}

"Halláronse en la ciudad en ciertos templos a ella comarcanos, muchas estatuas y figuras de oro y plata enteras, hechas a la forma toda de una mujer y del tamaño de ella..." (p. 393)

\begin{tabular}{|c|c|c|c|c|c|c|}
\hline Meio de Troca & $\begin{array}{c}\text { Meio de } \\
\text { Pagamento }\end{array}$ & $\begin{array}{c}\text { Medida de } \\
\text { Valor }\end{array}$ & Entesouramento & Reciprocidade & $\begin{array}{c}\text { Mágico- } \\
\text { Religioso }\end{array}$ & $\begin{array}{c}\text { Objeto de } \\
\text { Prestígio }\end{array}$ \\
\hline & & & & & $\mathrm{x}$ & \\
\hline
\end{tabular}

\section{$\underline{\text { Ficha } \mathrm{N}^{\circ} 78}$}

Autor: Poma de Ayala

\section{Objeto (s): ouro}

"Fue (Uiracocha Inga) casado con Mama Yunto Cayan Coya y murió en el Cuzco de la edad de ciento y veinte y cuatro años, y dejó el templo del sol todo de oro macizo." (Ayala, 107: 84).

\begin{tabular}{|c|c|c|c|c|c|c|}
\hline Meio de Troca & $\begin{array}{c}\text { Meio de } \\
\text { Pagamento }\end{array}$ & $\begin{array}{c}\text { Medida de } \\
\text { Valor }\end{array}$ & Entesouramento & Reciprocidade & $\begin{array}{c}\text { Mágico- } \\
\text { Religioso }\end{array}$ & $\begin{array}{c}\text { Objeto de } \\
\text { Prestígio }\end{array}$ \\
\hline & & & & & $\mathrm{x}$ & \\
\hline
\end{tabular}

$\underline{\text { Ficha } \mathrm{N}^{\circ} 79}$

Autor: Poma de Ayala

Objeto (s): prata

"Y la dicha Mama Uaco Coya tenía su vestido de rosado y tenía sua topos muy grandes de plata, y que murió en el Cuzco de edad de doscientos años en el tiempo de su hijo Sinche Roca Inga [...]." (Ayala, 121: 96).

\begin{tabular}{|c|c|c|c|c|c|c|}
\hline Meio de Troca & $\begin{array}{c}\text { Meio de } \\
\text { Pagamento }\end{array}$ & $\begin{array}{c}\text { Medida de } \\
\text { Valor }\end{array}$ & Entesouramento & Reciprocidade & $\begin{array}{c}\text { Mágico- } \\
\text { Religioso }\end{array}$ & $\begin{array}{c}\text { Objeto de } \\
\text { Prestígio }\end{array}$ \\
\hline & & & & & & $\mathrm{x}$ \\
\hline
\end{tabular}

\section{Ficha $\mathrm{N}^{\circ} 80$}

Autor: Poma de Ayala

\section{Objeto (s): ouro e prata}

"Y se murió de edad de ciento y veinte años y dejó mucha riqueza, repartió en tres partes en el testamento lo primero para el sol, lo segundo para la luna, lo tercero para sus hijos, que así lo habia y así lo cuentan los dichos viejos que los supieran; e hizo muy grandes vestidos y ropa y 
de cumbe y de auasca y riquezas y vajillas de oro y plata, y de todo lo demás riquezas y ropa que tenía." (Ayala, 131: 105).

\begin{tabular}{|c|c|c|c|c|c|c|}
\hline Meio de Troca & $\begin{array}{c}\text { Meio de } \\
\text { Pagamento }\end{array}$ & $\begin{array}{c}\text { Medida de } \\
\text { Valor }\end{array}$ & Entesouramento & Reciprocidade & $\begin{array}{c}\text { Mágico- } \\
\text { Religioso }\end{array}$ & $\begin{array}{c}\text { Objeto de } \\
\text { Prestígio }\end{array}$ \\
\hline & & & & & & $\mathrm{x}$ \\
\hline
\end{tabular}

\section{Ficha $\mathrm{N}^{\circ} 81$}

Autor: Poma de Ayala

\section{Objeto (s): ouro e prata}

"Tenía grandes riquezas, haciendas y chácaras, y casas y ganado, y mucha criadas y vajillas de oro y plata, y tría lacayos alabardas, y en companía traía señores grandes y principales y caballeros, y traís muy muchas doncellas." (Ayala, 141: 111).

\begin{tabular}{|c|c|c|c|c|c|c|}
\hline Meio de Troca & $\begin{array}{c}\text { Meio de } \\
\text { Pagamento }\end{array}$ & $\begin{array}{c}\text { Medida de } \\
\text { Valor }\end{array}$ & Entesouramento & Reciprocidade & $\begin{array}{c}\text { Mágico- } \\
\text { Religioso }\end{array}$ & $\begin{array}{c}\text { Objeto de } \\
\text { Prestígio }\end{array}$ \\
\hline & & & & & & $\mathrm{x}$ \\
\hline
\end{tabular}

\section{Ficha $\mathrm{N}^{\circ} 82$}

Autor: Poma de Ayala

\section{Objeto (s): ouro e prata}

"En este mes, el Inga y todo el reino sacrificaban gran suma de oro y plata y ganados a las dichas uacas, ídolos principales, primero al sol y a la luna y a la estrella y a los templos y dioses y uacabilca que estaban en lo más altos cerros y nieves." (Ayala, 239 / 241: 177-180).

\begin{tabular}{|c|c|c|c|c|c|c|}
\hline Meio de Troca & $\begin{array}{c}\text { Meio de } \\
\text { Pagamento }\end{array}$ & $\begin{array}{c}\text { Medida de } \\
\text { Valor }\end{array}$ & Entesouramento & Reciprocidade & $\begin{array}{c}\text { Mágico- } \\
\text { Religioso }\end{array}$ & $\begin{array}{c}\text { Objeto de } \\
\text { Prestígio }\end{array}$ \\
\hline & & & & & $\mathrm{x}$ & \\
\hline
\end{tabular}

$\underline{\text { Ficha } \mathrm{N}^{\circ} 83}$

Autor: Poma de Ayala

\section{Objeto (s): ouro, prata e mullu}

"Junio. Cuzqui Quilla. Este mês hacían la moderada fiesta del Inti Raymi, y se gastaba mucho en ello, y sacrificaban al sol, y enterraba al sacrifício llamado cápac ocha, que enterraban a los niños inocentes, quinientos, y mucho oro y plata y mullu y en este dicho mês en todo el reino." (Ayala, 247 / 249: 183).

\begin{tabular}{|c|c|c|c|c|c|c|}
\hline Meio de Troca & $\begin{array}{c}\text { Meio de } \\
\text { Pagamento }\end{array}$ & $\begin{array}{c}\text { Medida de } \\
\text { Valor }\end{array}$ & Entesouramento & Reciprocidade & $\begin{array}{c}\text { Mágico- } \\
\text { Religioso }\end{array}$ & $\begin{array}{c}\text { Objeto de } \\
\text { Prestígio }\end{array}$ \\
\hline & & & & & $\mathrm{x}$ & \\
\hline
\end{tabular}




\section{Ficha $\mathrm{N}^{\circ} 84$}

Autor: Poma de Ayala

\section{Objeto (s): mullu}

"Agosto. Cahcrayapuy quilla. Que este mês entran a trabajar, aran y rompen tierras simples para sembrar maíz, en este mês sacrificaban en los ídolos, uacas, pobres de este reino con lo que podían, con cuyes, y mullu, y zanco, y chicha, y carneros [...]." (Ayala, 251 / 253: 186).

\begin{tabular}{|c|c|c|c|c|c|c|}
\hline Meio de Troca & $\begin{array}{c}\text { Meio de } \\
\text { Pagamento }\end{array}$ & $\begin{array}{c}\text { Medida de } \\
\text { Valor }\end{array}$ & Entesouramento & Reciprocidade & $\begin{array}{c}\text { Mágico- } \\
\text { Religioso }\end{array}$ & $\begin{array}{c}\text { Objeto de } \\
\text { Prestígio }\end{array}$ \\
\hline & & & & & $\mathrm{x}$ & \\
\hline
\end{tabular}

\section{$\underline{\text { Ficha } \mathrm{N}^{\circ} 85}$}

Autor: Poma de Ayala

\section{Objeto (s): plumas, prata e ouro.}

"Este mes fue el mês de los difuntos, aya quiere decir difunto, es la fiesta de los difuntos. En este mes sacan los difuntos de sus bóvedas que llaman pucullo, y le dan de comer y beber, y le visten de sus vestidos ricos, y le ponen plumas en la cabeza, y cantan y danzan con ellos, y le ponen unas andas y anda con ellas en casa en casa y por las calles y por la plaza, y después tornan a meterlos en sus pucullos dándole sus comidas y vajilla, al principal de plata y oro, y al pobre de barro, y le dan sus carneros y ropa y los entierran con ellas y gastan en esta fiesta muy mucho." (Ayala, 255 / 257: 189).

\begin{tabular}{|c|c|c|c|c|c|c|}
\hline Meio de Troca & $\begin{array}{c}\text { Meio de } \\
\text { Pagamento }\end{array}$ & $\begin{array}{c}\text { Medida de } \\
\text { Valor }\end{array}$ & Entesouramento & Reciprocidade & $\begin{array}{c}\text { Mágico- } \\
\text { Religioso }\end{array}$ & $\begin{array}{c}\text { Objeto de } \\
\text { Prestígio }\end{array}$ \\
\hline & & & & & $\mathrm{x}$ & $\mathrm{x}$ \\
\hline
\end{tabular}

\section{Ficha $\mathrm{N}^{\circ} 86$}

Autor: Poma de Ayala

\section{Objeto (s): ouro, prata, mullu}

"Que en este mês hacía grandes sacrifícios al sol, mucho oro y mucha plata y vajillas, que entierran quinientos niños inocentes y niñas, los entierran parados, vivos, con sus vajillas de oro y plata, y mucho mullu y ganados [...]." (Ayala, 259 / 261: 192)

\begin{tabular}{|c|c|c|c|c|c|c|}
\hline Meio de Troca & $\begin{array}{c}\text { Meio de } \\
\text { Pagamento }\end{array}$ & $\begin{array}{c}\text { Medida de } \\
\text { Valor }\end{array}$ & Entesouramento & Reciprocidade & $\begin{array}{c}\text { Mágico- } \\
\text { Religioso }\end{array}$ & $\begin{array}{c}\text { Objeto de } \\
\text { Prestígio }\end{array}$ \\
\hline & & & & & $\mathrm{x}$ & $\mathrm{x}$ \\
\hline
\end{tabular}

Ficha $\mathrm{N}^{\circ} 87$

Autor: Poma de Ayala

Objeto (s): ouro e prata 
"De cómo el Inga sacrificaba a su padre el sol con oro y plata, y con niños y niñas de diez, que no tuviesen señal ni mancha ni lunar y fuesen hermosos; y para ello hacían juntar quinientos niños de todo el reino y sacrificaban en el templo de Coricancha, que todas las paredes altas y bajas estaban guarnecidas de oro finíssimo, y en lo alto del techo estaba colgados muchos cristales, y a los dos lados dos leones apuntando el sol." (Ayala, 262 / 264: 195).

\begin{tabular}{|c|c|c|c|c|c|c|}
\hline Meio de Troca & $\begin{array}{c}\text { Meio de } \\
\text { Pagamento }\end{array}$ & $\begin{array}{c}\text { Medida de } \\
\text { Valor }\end{array}$ & Entesouramento & Reciprocidade & $\begin{array}{c}\text { Mágico- } \\
\text { Religioso }\end{array}$ & $\begin{array}{c}\text { Objeto de } \\
\text { Prestígio }\end{array}$ \\
\hline & & & & & $\mathrm{x}$ & $\mathrm{x}$ \\
\hline
\end{tabular}

Ficha $N^{\circ} 88$

Autor: Poma de Ayala

Objeto (s): ouro, prata, coca, mullu e cobre

"Estas dichas fiestas se hacían con grandes taquies y danzas y sacrificios al dios Uanacauri y a Pacha cámac, dos de los Ingas con diez niños y con otras cosas. Tambiém sacrificaba al Pacaritambo con diez niños y oro y plata, de adonde dicen que salió el dicho Inga. Todo esto ordenó Mango Cápac Inga. [...] De cómo sacrificaban al Illapa, al rayo, que agora les llaman Santiago, quemando coca y conidas, y chicha, ayunando sal y no durmiendo con sus mujeres, ni las dichas mujeres con sus maridos, velando una noche, paraciconmi, zariconmi; y por outro nombre le llaman curi caccha, illapa. De cómo ordenó vestidos y ropa de sus dioses uacas, se llaman Cápac ocha. Lo hacían de cumbi y de auasca, y de su vajilla de oro y plata, y de barro, y mollo y cobre, y donde soterraba."

(Ayala, 265 / 267: 198-199)

\begin{tabular}{|c|c|c|c|c|c|c|}
\hline Meio de Troca & $\begin{array}{c}\text { Meio de } \\
\text { Pagamento }\end{array}$ & $\begin{array}{c}\text { Medida de } \\
\text { Valor }\end{array}$ & Entesouramento & Reciprocidade & $\begin{array}{c}\text { Mágico- } \\
\text { Religioso }\end{array}$ & $\begin{array}{c}\text { Objeto de } \\
\text { Prestígio }\end{array}$ \\
\hline & & & & & $\mathrm{x}$ & $\mathrm{x}$ \\
\hline
\end{tabular}

Ficha $\mathrm{N}^{\circ} 89$

Autor: Poma de Ayala

Objeto (s): coca, mullu, prata, ouro e ají

"Idolos y uacas de los Chinchaysuyuos, que tenían los principales de Uarco, Pacha cámac, aysa vilca. Sacrificaban con criaturas de cinco años, u con colores y algodones, tupa, coca, y fruta y chicha. Y los indios Yauyos al ídolo de Pariacaca sacrificaban con chicha y mollo y uaccri zanco, y comidas y conejos. Los indios Uancas, Xauxa, Hanan Uanca, Lurin Uanca, sacrificaban con perros, porque ellos comían perros, y así sacrificaban con ello y con coca, y 
comidas, y sangre de perro y mollo [...] Aymarais sacrificaban Quichi calla, con plata y oro, y con cinco niños y carneros pacos, y ajy, y lana de colores en cada año." (Ayala, 267 / 269: 199-202)

\begin{tabular}{|c|c|c|c|c|c|c|}
\hline Meio de Troca & $\begin{array}{c}\text { Meio de } \\
\text { Pagamento }\end{array}$ & $\begin{array}{c}\text { Medida de } \\
\text { Valor }\end{array}$ & Entesouramento & Reciprocidade & $\begin{array}{c}\text { Mágico- } \\
\text { Religioso }\end{array}$ & $\begin{array}{c}\text { Objeto de } \\
\text { Prestígio }\end{array}$ \\
\hline & & & & & $\mathrm{x}$ & $\mathrm{x}$ \\
\hline
\end{tabular}

$\underline{\text { Ficha } \mathrm{N}^{\circ} 90}$

Autor: Poma de Ayala

\section{Objeto (s): coca e pluma}

"Idolos y uacas de los Andesuyos. Sacrificaban los indios que estaban fuera de la montaña llamada Haua Anti, adoraban el tigre otorongo [...] y sacrificaban con sebo quemado de culebra, y maíz, y coca, y pluma de pájaros de los Andes, los queman y adoran con ella a los otorongos, así mismo adoran los árboles de la cocaque comen ellos, y así les llaman cocamama, y lo besan, luego lo meten en la boca." (Ayala, 269 / 271: 202)

\begin{tabular}{|c|c|c|c|c|c|c|}
\hline Meio de Troca & $\begin{array}{c}\text { Meio de } \\
\text { Pagamento }\end{array}$ & $\begin{array}{c}\text { Medida de } \\
\text { Valor }\end{array}$ & Entesouramento & Reciprocidade & $\begin{array}{c}\text { Mágico- } \\
\text { Religioso }\end{array}$ & $\begin{array}{c}\text { Objeto de } \\
\text { Prestígio }\end{array}$ \\
\hline & & & & & $\mathrm{x}$ & \\
\hline
\end{tabular}

\section{Ficha $\mathrm{N}^{\circ} 91$}

Autor: Poma de Ayala

\section{Objeto (s): coca, mullu, pluma, ouro e prata}

"Toda la província de Colla suyo, collas, sacrificaban Puquina Urco, Cala Circa, Suri Urco, sacrificaban con carneros negros y cestos de coca y con diez niños de un año, y conejos y mullu y pluma de suri quemandolo, sahumaban a las dichas uacas ídolos y sacrifícios Puquina colla Urco colla sacrificaban con carneros blancos de cuyro y vajilla de barro y mucha chicha de canaua y moraya y mullu comidas y pescado fresco y seco echaban a la laguna de Puquina y lo consumían a la uaca de Titicaca, sacrificaban con mucho oro y plata y vestidos y con veinte niños de dos años." (Ayala, 271 / 273: 202)

\begin{tabular}{|c|c|c|c|c|c|c|}
\hline Meio de Troca & $\begin{array}{c}\text { Meio de } \\
\text { Pagamento }\end{array}$ & $\begin{array}{c}\text { Medida de } \\
\text { Valor }\end{array}$ & Entesouramento & Reciprocidade & $\begin{array}{c}\text { Mágico- } \\
\text { Religioso }\end{array}$ & $\begin{array}{c}\text { Objeto de } \\
\text { Prestígio }\end{array}$ \\
\hline & & & & & $\mathrm{x}$ & \\
\hline
\end{tabular}




\section{Ficha $\mathrm{N}^{\circ} 92$}

Autor: Poma de Ayala

\section{Objeto (s): ouro, prata, coca e mullu}

"Que cada uno tuvieron sus dioses ídolos y uacas puestos de los ingas para el sacrificio; que como sacrificaban la uaca ídolo de Coropona, Urco con oro y plata y con niños de doce años y umas de pariuana y de uachiua y coca y mullu y sanco y carne cruda, y sangre cruda, con ella haciendo sanco, y a esto les llamaban yauar-zanco." (Ayala, 273 / 275: 203)

\begin{tabular}{|c|c|c|c|c|c|c|}
\hline Meio de Troca & $\begin{array}{c}\text { Meio de } \\
\text { Pagamento }\end{array}$ & $\begin{array}{c}\text { Medida de } \\
\text { Valor }\end{array}$ & Entesouramento & Reciprocidade & $\begin{array}{c}\text { Mágico- } \\
\text { Religioso }\end{array}$ & $\begin{array}{c}\text { Objeto de } \\
\text { Prestígio }\end{array}$ \\
\hline & & & & & $\mathrm{x}$ & \\
\hline
\end{tabular}

$\underline{\text { Ficha } N^{\circ} 93}$

Autor: Poma de Ayala

Objeto (s): coca

"Otros hechiceros entrando a dormir a las cuevas y adoran a las dichas cuevas, y dice machay mamam ama micuuanquicho allilla punochiay: cueva, no me comáis, hazme dormir bien y guárdame esta noche. Diciendo esto le dan de comer maíz mascado o coca y le emplasta el dicho cueva; y hasta este tiempo lo usan los indios. (Ayala, 276 / 278: 205).

\begin{tabular}{|c|c|c|c|c|c|c|}
\hline Meio de Troca & $\begin{array}{c}\text { Meio de } \\
\text { Pagamento }\end{array}$ & $\begin{array}{c}\text { Medida de } \\
\text { Valor }\end{array}$ & Entesouramento & Reciprocidade & $\begin{array}{c}\text { Mágico- } \\
\text { Religioso }\end{array}$ & $\begin{array}{c}\text { Objeto de } \\
\text { Prestígio }\end{array}$ \\
\hline & & & & & $\mathrm{x}$ & \\
\hline
\end{tabular}

\section{$\underline{\text { Ficha } N^{\circ} 94}$}

Autor: Poma de Ayala

\section{Objeto (s): coca}

"Otros hichiceros toman sebo de carnero y de culebra y de león y de otros animales, y maíz y sangre y chicha y coca, y lo queman y hacen hablar del fuego a los demonios y les preguntan y les responden, y dicen lo que há de haber y lo que pasa, por ellos lo saben. Todos los que comen coca son hechiceros que hablan con los demonios estando borrachos, no loestando, y se tornan locos los que comen coca. Dios nos guarde. Y así no se le puede dar sacramento al que come coca." (Ayala, 278 / 280: 207).

\begin{tabular}{|c|c|c|c|c|c|c|}
\hline Meio de Troca & $\begin{array}{c}\text { Meio de } \\
\text { Pagamento }\end{array}$ & $\begin{array}{c}\text { Medida de } \\
\text { Valor }\end{array}$ & Entesouramento & Reciprocidade & $\begin{array}{c}\text { Mágico- } \\
\text { Religioso }\end{array}$ & $\begin{array}{c}\text { Objeto de } \\
\text { Prestígio }\end{array}$ \\
\hline & & & & & $\mathrm{x}$ & \\
\hline
\end{tabular}




\section{Ficha $\mathrm{N}^{\circ} 95$}

Autor: Poma de Ayala

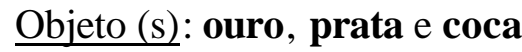

"Entierro del Inga. Cómo fue enterrado el Inga y abalzamaron sin menearle el cuerpo, y le pusieron los ojos y el rostro como si estuviera vivo, y le vestían ricas vestiduras, y al difunto le llamaron yllapa, que todos los demás difuntos les llamaban aya; y le enterraban con mucha vasija de oro y plata, y a los pajes y camareros y mujeres que él quería le matan, y la mujer la más querida la llevaba por señora coya, y para ahogar estos, primeros les emborrachaban y dicen que les hacían abrir la boca y le soplaban con coca molida hecho polvo, todos iban embalsamados y los ponía sus lados, y tenían un mês el cuerpo[...] Todo aquel mês hasta enterrarlo ayunaban sal todo lo acostumbrado, y ofrecen oro o plata y ganados, ropa, comida, en todo el reino." (Ayala, 288 / 290: 216).

\begin{tabular}{|c|c|c|c|c|c|c|}
\hline Meio de Troca & $\begin{array}{c}\text { Meio de } \\
\text { Pagamento }\end{array}$ & $\begin{array}{c}\text { Medida de } \\
\text { Valor }\end{array}$ & Entesouramento & Reciprocidade & $\begin{array}{c}\text { Mágico- } \\
\text { Religioso }\end{array}$ & $\begin{array}{c}\text { Objeto de } \\
\text { Prestígio }\end{array}$ \\
\hline & & & & & $\mathrm{x}$ & $\mathrm{x}$ \\
\hline
\end{tabular}

$\underline{\text { Ficha } N^{\circ} 96}$

Autor: Poma de Ayala

\section{Objeto (s): ouro, prata e coca}

"Y de allí nunca más lo ven en toda su vida, ni se acuerda de ello, ni saben ninguma ceremonia como los indios de la sierra, que al difunto hasta meterle en la boca oro y plata y coca lo hacen y lo enterran con sus ojotas, y vestidos y comidas, con todo ello entierran hasta los topos de plata los entierra, diecen que se la lleva." (Ayala, 292 / 294: 218-221).

\begin{tabular}{|c|c|c|c|c|c|c|}
\hline Meio de Troca & $\begin{array}{c}\text { Meio de } \\
\text { Pagamento }\end{array}$ & $\begin{array}{c}\text { Medida de } \\
\text { Valor }\end{array}$ & Entesouramento & Reciprocidade & $\begin{array}{c}\text { Mágico- } \\
\text { Religioso }\end{array}$ & $\begin{array}{c}\text { Objeto de } \\
\text { Prestígio }\end{array}$ \\
\hline & & & & & $\mathrm{x}$ & $\mathrm{x}$ \\
\hline
\end{tabular}

\section{Ficha $\mathrm{N}^{\circ} 97$}

Autor: Poma de Ayala

Objeto (s): ouro e prata.

"Que los ídolos y Uacas mayores que sacrificaba muy mucho el Inga hacia Chichay suyu: Zupaico, Zupa raura, Quichi calla, Pariacaca, Caruancho, Uallullo, Ayza bilca, Pachacámac, Ancolla, Ancacilla, Caruarazo, Razubilca. De los Andesuyos y del Inga: Uanacauri, Sauasiray, Pitusiray, Achapalla, Canacuay, Apotinya. De los Collasuyos: Ausancata, 
Uillcanota, Ayauire, Pomacanchi. De los Condesuyos: Coropona, Putina. Estos fueron los más estimados y sacrificados con mucho oro y plata." (Ayala, 275 / 277: 204).

\begin{tabular}{|c|c|c|c|c|c|c|}
\hline Meio de Troca & $\begin{array}{c}\text { Meio de } \\
\text { Pagamento }\end{array}$ & $\begin{array}{c}\text { Medida de } \\
\text { Valor }\end{array}$ & Entesouramento & Reciprocidade & $\begin{array}{c}\text { Mágico- } \\
\text { Religioso }\end{array}$ & $\begin{array}{c}\text { Objeto de } \\
\text { Prestígio }\end{array}$ \\
\hline & & & & & $\mathrm{x}$ & $\mathrm{x}$ \\
\hline
\end{tabular}

Ficha $N^{\circ} 98$

Autor: Poma de Ayala

Objeto (s): plumas, prata e ouro.

"Todo son borracheras, y al difunto dicen que le lavan el cuerpo y le visten todos sus vestidos y plumas y joyas de plata o de oro, y le ponen en unas andas y van a la procesión; como dicho es, cantan y van saltando y llorando cada ayllo y parcialidad como su costumbre." (Ayala, 290 / 292: 218).

\begin{tabular}{|c|c|c|c|c|c|c|}
\hline Meio de Troca & $\begin{array}{c}\text { Meio de } \\
\text { Pagamento }\end{array}$ & $\begin{array}{c}\text { Medida de } \\
\text { Valor }\end{array}$ & Entesouramento & Reciprocidade & $\begin{array}{c}\text { Mágico- } \\
\text { Religioso }\end{array}$ & $\begin{array}{c}\text { Objeto de } \\
\text { Prestígio }\end{array}$ \\
\hline & & & & & $\mathrm{x}$ & $\mathrm{x}$ \\
\hline
\end{tabular}

\section{Ficha $\mathrm{N}^{\circ} 99$}

Autor: Poma de Ayala

Objeto (s): ouro e prata

"Cómo fueran enterrados de los indios de Collasuyo. Primero vístenle y luego le lloran en el primer día, y en los cinco les entierran asentado con mucha vestidura y vajillas de oro y de plata, y de barro si es indio pobre; le hacen llevar mucha comida y al difunto le envían otros indios o indias, a otros difuntos, a sus padres o a su madre o a los parientes y hermanos y amigos, le envía de comer o chicha o agua, oro, plata, vajillas y ropa, o de otras cosas, y con ello le entierran al difunto, en los cinco días, como dicho es." (Ayala, 294 / 296: 221).

\begin{tabular}{|c|c|c|c|c|c|c|}
\hline Meio de Troca & $\begin{array}{c}\text { Meio de } \\
\text { Pagamento }\end{array}$ & $\begin{array}{c}\text { Medida de } \\
\text { Valor }\end{array}$ & Entesouramento & Reciprocidade & $\begin{array}{c}\text { Mágico- } \\
\text { Religioso }\end{array}$ & $\begin{array}{c}\text { Objeto de } \\
\text { Prestígio }\end{array}$ \\
\hline & & & & & $\mathrm{x}$ & $\mathrm{x}$ \\
\hline
\end{tabular}

\section{Ficha $\mathrm{N}^{\circ} 100$}

Autor: Poma de Ayala

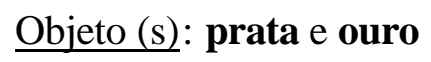

"Y en el ayunar sal y hacer pacarico y comer carne cruda y beber sangre cruda es común del reino desde los ingas hasta ahora pero dicen que sacan las tripas y hacen bálsamo, y le visten muy rica vestidura y luego le lloran; con ello beben mucha chicha y meten en la boca plata, también es común de meter plata u oro en la boca del difunto." (Ayala, 296 / 298: 221). 


\begin{tabular}{|c|c|c|c|c|c|c|}
\hline Meio de Troca & $\begin{array}{c}\text { Meio de } \\
\text { Pagamento }\end{array}$ & $\begin{array}{c}\text { Medida de } \\
\text { Valor }\end{array}$ & Entesouramento & Reciprocidade & $\begin{array}{c}\text { Mágico- } \\
\text { Religioso }\end{array}$ & $\begin{array}{c}\text { Objeto de } \\
\text { Prestígio }\end{array}$ \\
\hline & & & & & $\mathrm{x}$ & $\mathrm{x}$ \\
\hline
\end{tabular}

\section{$\underline{\text { Ficha } \mathrm{N}^{\circ} 101}$}

Autor: Poma de Ayala

\section{Objeto (s): mullu}

"Perlas del Inga y de sus principales que son piedras preciosas se llamaban quispe perlas, piedras preciosas unima, cuychi, uacccri, y collares se llamaba mullo, estas dichas cosas había en tiempo del Inga en este reino." (Ayala, 332 / 334: 250).

\begin{tabular}{|c|c|c|c|c|c|c|}
\hline Meio de Troca & $\begin{array}{c}\text { Meio de } \\
\text { Pagamento }\end{array}$ & $\begin{array}{c}\text { Medida de } \\
\text { Valor }\end{array}$ & Entesouramento & Reciprocidade & $\begin{array}{c}\text { Mágico- } \\
\text { Religioso }\end{array}$ & $\begin{array}{c}\text { Objeto de } \\
\text { Prestígio }\end{array}$ \\
\hline & & & & & & $\mathrm{x}$ \\
\hline
\end{tabular}

$\underline{\text { Ficha } \mathrm{N}^{\circ} 102}$

Autor: Poma de Ayala

\section{Objeto (s): coca}

"En tiempo de fiesta y pascua les repartían en la plaza pública unos cestos grandísimos de coca llamados auan cari, y unos carneros grandísimos de la plaza, se los llevaban unos cayua con el hato, otros le derribaba los carneros; esta fiesta el Inga y los demás señores se reían y se entretenían en esta fiesta en las ciudades." (Ayala, 337 / 339: 254).

\begin{tabular}{|c|c|c|c|c|c|c|}
\hline Meio de Troca & $\begin{array}{c}\text { Meio de } \\
\text { Pagamento }\end{array}$ & $\begin{array}{c}\text { Medida de } \\
\text { Valor }\end{array}$ & Entesouramento & Reciprocidade & $\begin{array}{c}\text { Mágico- } \\
\text { Religioso }\end{array}$ & $\begin{array}{c}\text { Objeto de } \\
\text { Prestígio }\end{array}$ \\
\hline & & & & $\mathrm{x}$ & & \\
\hline
\end{tabular}

$\underline{\text { Ficha } \mathrm{N}^{\circ} 103}$

Autor: Poma de Ayala

\section{Objeto (s): ouro}

"A los dichos señores naturales proprietarios, y principales, y curacas, mandocillos de cada provincia y pueblo de este reino; fue Cápac Apo Topa Inga Yupanqui, rey y señor hijo del sol, tenía su silla llamada tiana, de oro finíssimo, tan alto como un codo, fue rey y Inga en todo este reyno ahora lo es posee." (Ayala, 453 / 455: 349).

\begin{tabular}{|c|c|c|c|c|c|c|}
\hline Meio de Troca & $\begin{array}{c}\text { Meio de } \\
\text { Pagamento }\end{array}$ & $\begin{array}{c}\text { Medida de } \\
\text { Valor }\end{array}$ & Entesouramento & Reciprocidade & $\begin{array}{c}\text { Mágico- } \\
\text { Religioso }\end{array}$ & $\begin{array}{c}\text { Objeto de } \\
\text { Prestígio }\end{array}$ \\
\hline & & & & & & $\mathrm{x}$ \\
\hline
\end{tabular}




\section{Ficha $\mathrm{N}^{\circ} 104$}

Autor: Poma de Ayala

\section{Objeto (s): prata e ouro}

"Santa obra de misericordia; que los dichos padres han de tener cuidado de la santa buena obra de misericordia de todo lo demás que se guarde y del entierro de los cuerpos de los cristianos, de los difuntos, sea amortajado, descubierto la cara y manos y pies, porque los indios suelen poner algo en la cara y boca, plata, oro y comida, y en las manos lo próprio, en los pies ojotas al uso de los Ingas" (Ayala, 620 / 634: 502).

\begin{tabular}{|c|c|c|c|c|c|c|}
\hline Meio de Troca & $\begin{array}{c}\text { Meio de } \\
\text { Pagamento }\end{array}$ & $\begin{array}{c}\text { Medida de } \\
\text { Valor }\end{array}$ & Entesouramento & Reciprocidade & $\begin{array}{c}\text { Mágico- } \\
\text { Religioso }\end{array}$ & $\begin{array}{c}\text { Objeto de } \\
\text { Prestígio }\end{array}$ \\
\hline & & & & & $\mathrm{x}$ & $\mathrm{x}$ \\
\hline
\end{tabular}

\section{$\underline{\text { Ficha } \mathrm{N}^{\circ} 105}$}

Autor: Poma de Ayala

\section{Objeto (s): plumas, prata e ouro}

"Pues que en tiempo de los Ingas idólatras mandado de pontífices hechiceros, uizaconas, hacán a sus difuntos, el día que moría una persona mandaba matar un carnero, guacay, diciendo que se lo lleve cargado el dicho ánima del difunto, y le enterraba con sus vestidos y vajillas, y comidas, y llauto y plumas ojotas; en la boca le metían plata; oro; el dicho carnero lo daban a los que lloraban a comer en aquel día sin probar sal..." (Ayala, 785 / 799: 640-642).

\begin{tabular}{|c|c|c|c|c|c|c|}
\hline Meio de Troca & $\begin{array}{c}\text { Meio de } \\
\text { Pagamento }\end{array}$ & $\begin{array}{c}\text { Medida de } \\
\text { Valor }\end{array}$ & Entesouramento & Reciprocidade & $\begin{array}{c}\text { Mágico- } \\
\text { Religioso }\end{array}$ & $\begin{array}{c}\text { Objeto de } \\
\text { Prestígio }\end{array}$ \\
\hline & & & & & $\mathrm{x}$ & $\mathrm{x}$ \\
\hline
\end{tabular}


Tabela Geral - Número de citações total de cada objeto nos contextos estabelecidos.

\begin{tabular}{|c|c|c|c|c|c|c|c|c|}
\hline & $\begin{array}{l}\text { Mágico- } \\
\text { religioso }\end{array}$ & Prestígio & $\begin{array}{c}\text { Meio de } \\
\text { Pagamento }\end{array}$ & $\begin{array}{l}\text { Meio de } \\
\text { Troca }\end{array}$ & Reciprocidade & $\begin{array}{l}\text { Medida de } \\
\text { Valor }\end{array}$ & $\begin{array}{l}\text { Entesou- } \\
\text { ramento }\end{array}$ & Total \\
\hline Ouro & 45 & 23 & 6 & & 2 & 1 & & 77 \\
\hline Prata & 37 & 22 & 6 & 2 & 2 & 1 & & 70 \\
\hline Conchas & 13 & 4 & 2 & & & & & 19 \\
\hline Plumas & 11 & 4 & 4 & & & & & 19 \\
\hline Cobre & 1 & 1 & 2 & 1 & & 1 & & 6 \\
\hline Total & 140 & 63 & 38 & 12 & 8 & 5 & & 266 \\
\hline
\end{tabular}


Tabela - Número de citações total de cada objeto pelos cronistas.

\begin{tabular}{|c|c|c|c|c|c|c|c|c|c|c|}
\hline & $\begin{array}{c}\text { José de } \\
\text { Acosta }\end{array}$ & Anônimo & Ávila & $\begin{array}{c}\text { Poma de } \\
\text { Ayala }\end{array}$ & Betanzos & $\begin{array}{l}\text { Garci } \\
\text { Diez }\end{array}$ & Estete & Polo & $\begin{array}{c}\text { Vaca de } \\
\text { Castro }\end{array}$ & $\begin{array}{c}\text { Blas } \\
\text { Valera }\end{array}$ \\
\hline Ouro & 4 & 1 & & 21 & 17 & 1 & 5 & 2 & & 5 \\
\hline Prata & 4 & 1 & 1 & 20 & 10 & 2 & 5 & 2 & & 4 \\
\hline Coca & 7 & 2 & 7 & 10 & 10 & 11 & & & 1 & 2 \\
\hline Conchas & 3 & & 1 & 8 & & 1 & & & 1 & 2 \\
\hline Plumas & 4 & 1 & & 5 & 2 & 3 & & & & 1 \\
\hline Ají & 1 & 2 & & 1 & & 2 & & & 1 & \\
\hline Cobre & & 1 & & 1 & & 1 & & & & \\
\hline Total & 23 & 8 & 9 & 66 & 39 & 21 & 10 & 4 & 3 & 14 \\
\hline & & & & & & & & & & Total 197 \\
\hline
\end{tabular}


Gráficos: incidência de citações de ouro, prata e coca.

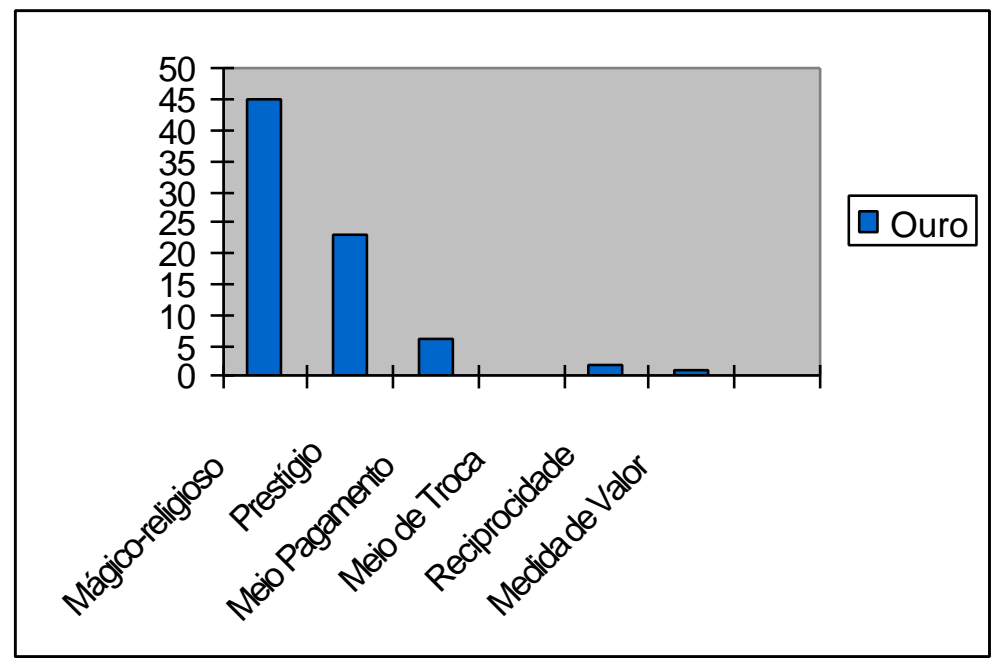

Incidência de citações do ouro.

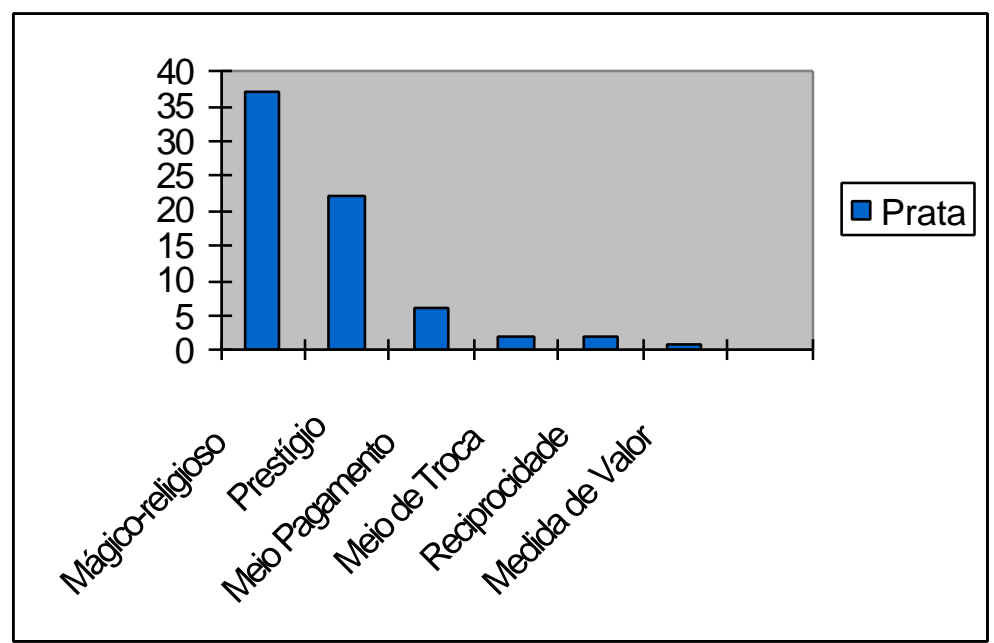

Incidência de citações da prata.

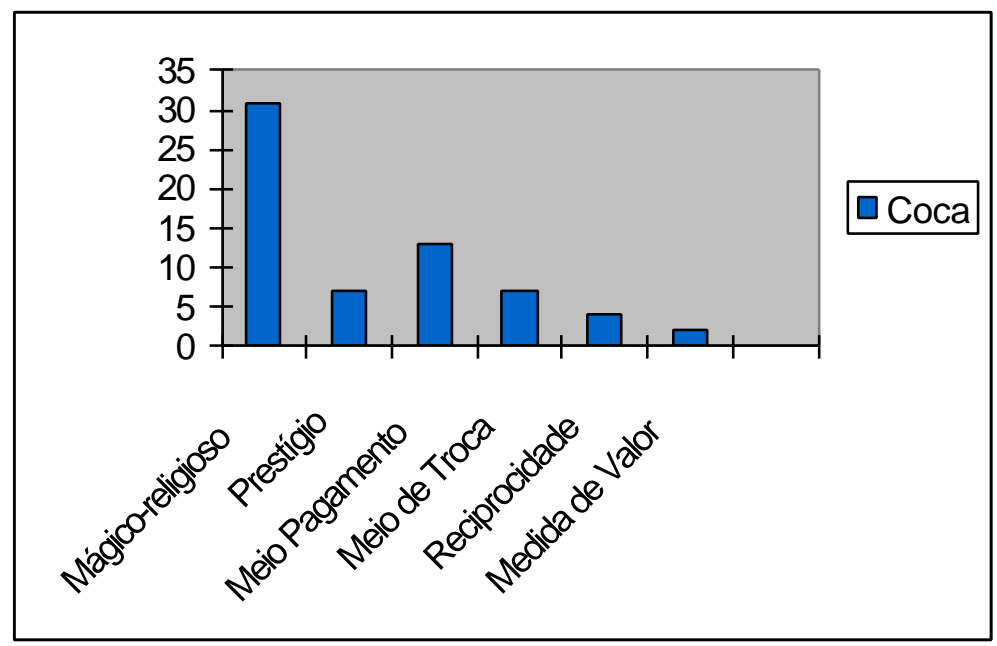

Incidência de citações das folhas de coca. 
Gráficos: incidência de citações das conchas marinhas, plumas e pimenta ají

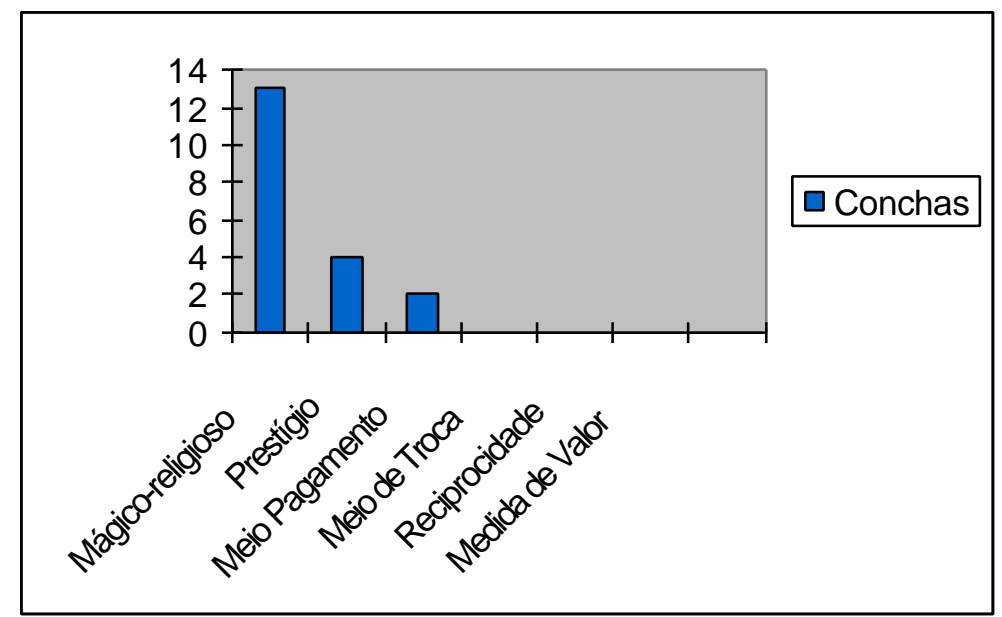

Incidência de citações das conchas marinhas.

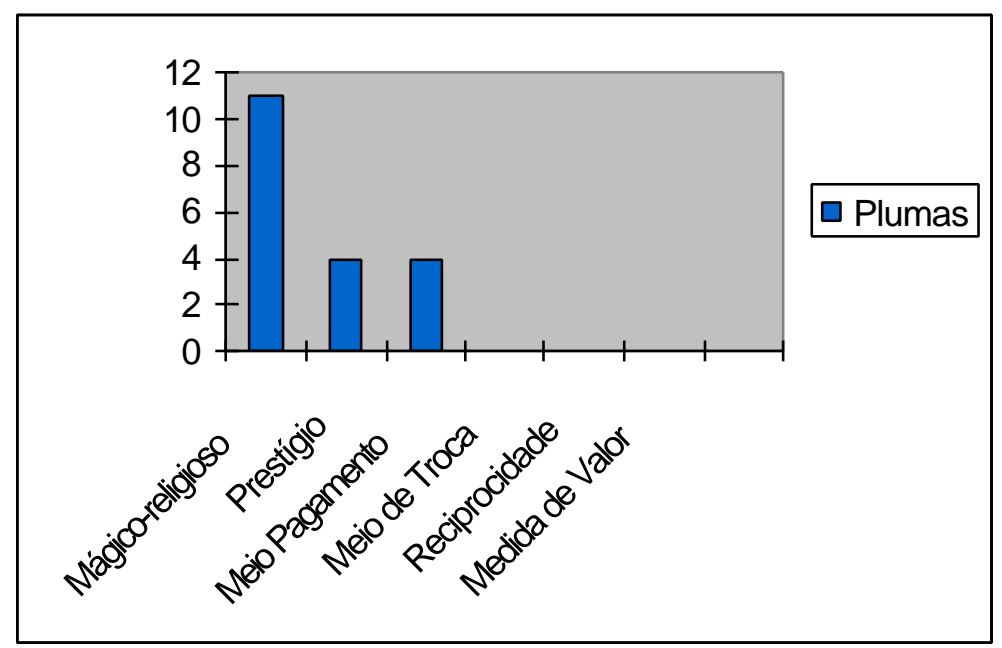

Incidência das citações de plumas.

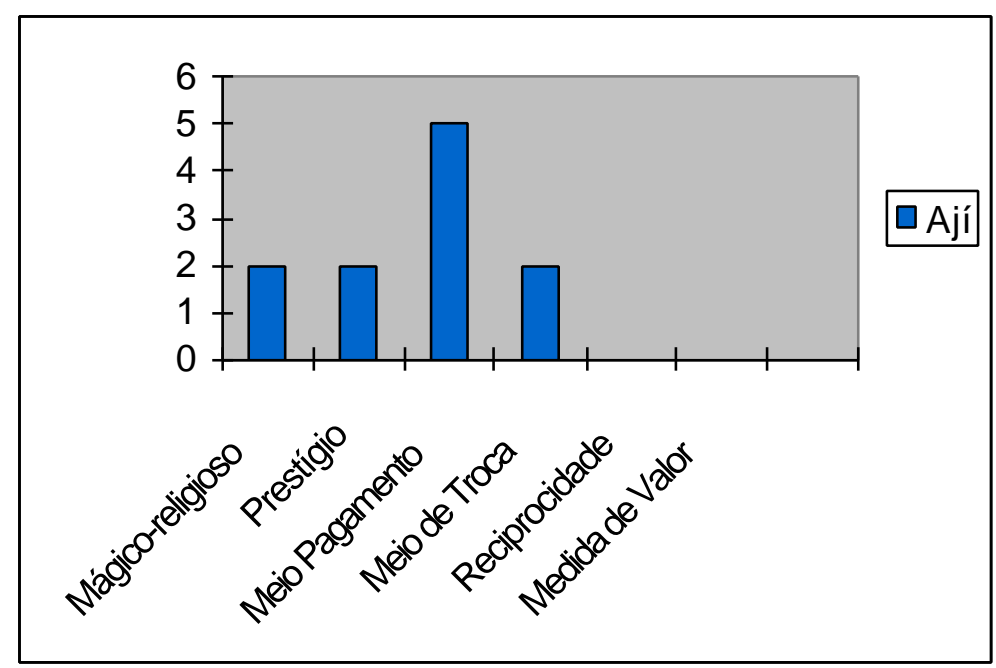

Incidência de citações da pimenta do tipo ají. 
Gráficos: incidência de citações de cobre, de todos objetos e contextos.

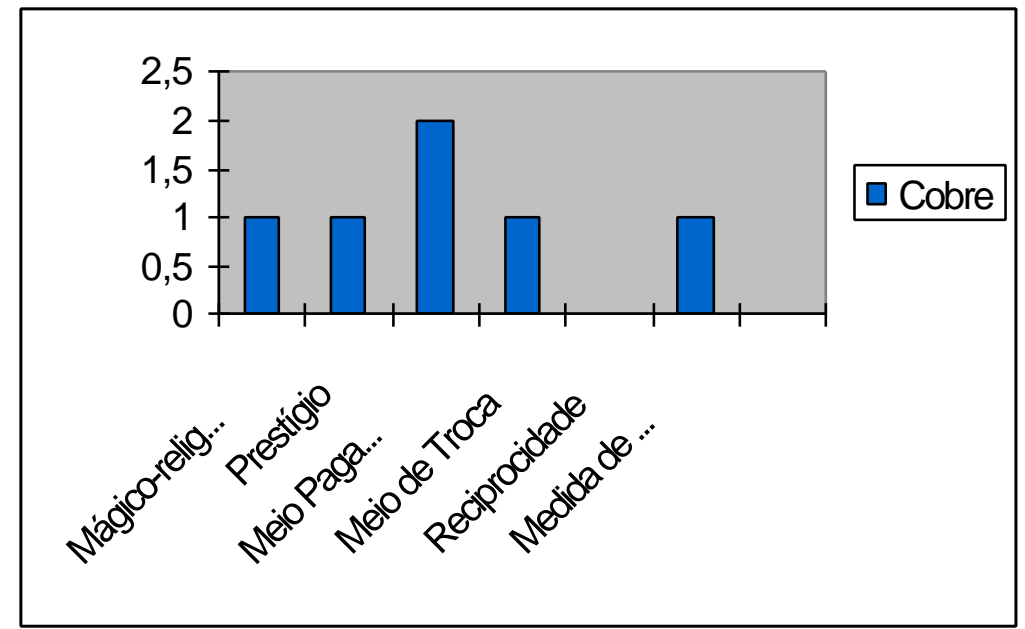

Incidência de citações do cobre (hachitas e naipes).
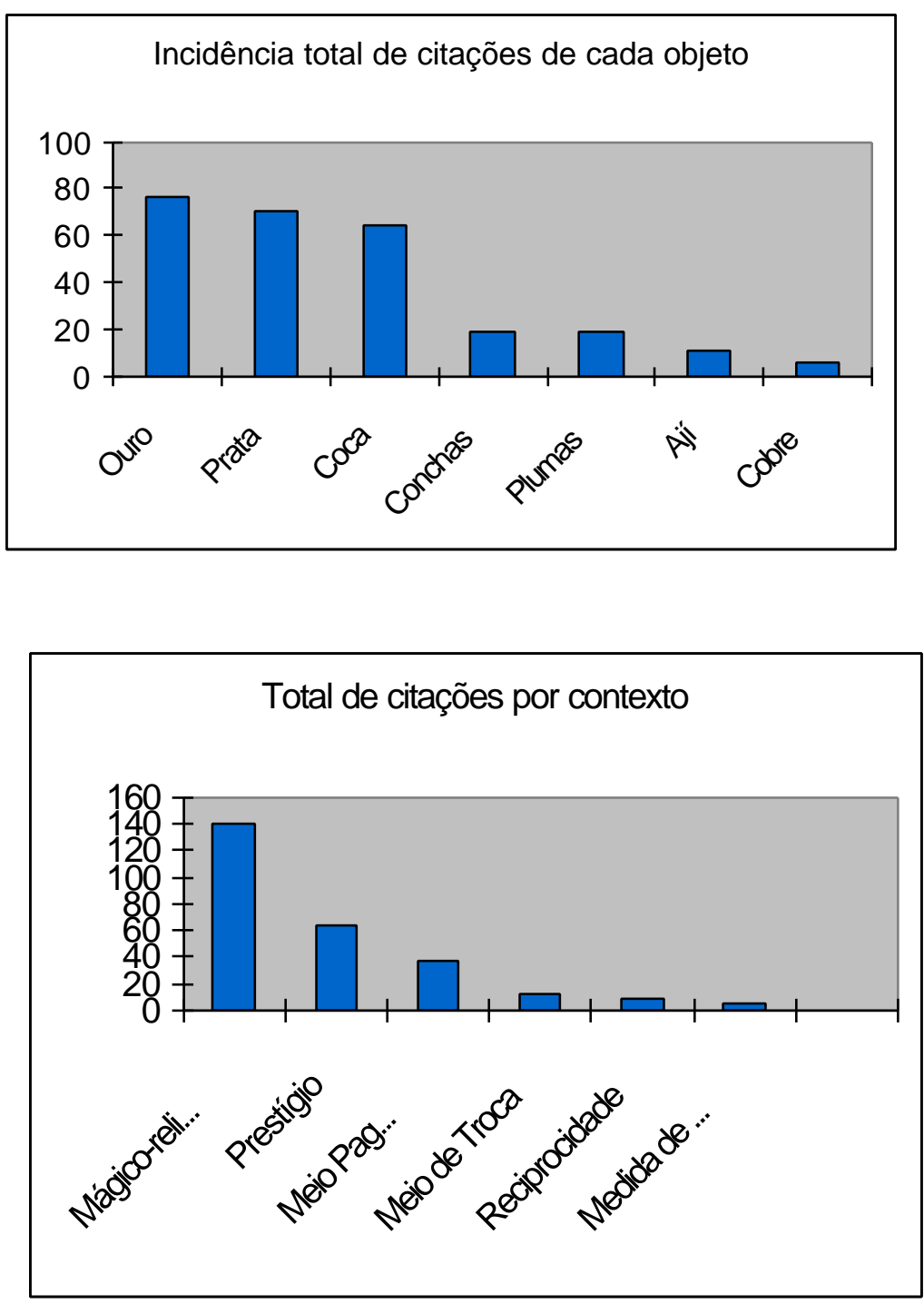


\section{FONTES ETNO-HISTÓRICAS UTILIZADAS NA PESQUISA}

ACOSTA, J. de (1590) História Natural y Moral de las Índias. México, Fondo de Cultura Económica, 1979.

ANÔNIMO DE CHINCHA (Pablo de Castro?) (1577?). "Aviso de el modo que havia en el govierno de los indios en tiempo del Inga y como se repatían las tierras y tributos". Revista Española de Antropología Americana. Madri, 1970. Vol. 5: 163-173.

ÁVILA, F. (1598?) Dioses y hombres de Huarochiri. Instituto de Estudios Peruanos, Lima, 1966.

AYALA, F. G. P. de (1613) Nueva Coronica y Buen Gobierno. Lima, Fondo de Cultura Económica, 1993, vols. I, II e III.

BETANZOS, J. D. de (1551) Suma y Narración de los Incas.

Disponível em: http://www.cervantesvirtual.org

DIEZ DE SAN MIGUEL, G. (1567) Visita hecha a la provincia de Chucuito por Garci Diez de San Miguel en el año de 1567. Lima, Ediciones de la Casa de la Cultura del Perú, 1964.

ESTETE, M. (1535) "Noticia del Perú". Boletín. Quito, Sociedad Ecuatoriana de Estudios Históricos Americanos, 1918, n.3: 347-402.

POLO DE ONDEGARDO, J. (1561) - "Informe del licenciado Juan Polo de Ondergado al licenciado Briviesca de Muñatones sobre la perpetuidad de las encomiendas en el Perú". Revista Histórica, Lima, Tomo XIII: 125-196. 
VACA DE CASTRO - "Ordenanzas de tambos. Distancias de unos a otros, modos de cargar los indios y obligaciones de las justicias respectivas hechas en la ciudad del Cuzco en 31 de mayo de 1543". Revista Histórica, Lima, 1909. Tomo III - IV: 427492.

VALERA, B.(1615?) "Relación de las Costumbres Antiguas de los Naturales del Perú". Revista del Archivo del Cuzco, Cuzo, 1953. 


\section{BIBLIOGRAFIA}

ADRIEN, K. J.; ADORNO, R. Transatlantic Encounters: Europeans and Andeans in the Sixteenth Century. Berkeley: University of California Press, 1991.

ALBERTI, G.; MAYER, E. (eds.) Reciprocidad e intercambio en los Andes peruanos. Instituto de Estudios Peruanos. Peru Problema 12, Lima, 1974.

ALCINA FRANCH, J. "La Vasija Trípode como Rasgo Diagnóstico para la Determinación de Influencias Mesoamericanas en el Área Andina". Primer Simposio de Correlaciones Antropológicas Andino-Mesoamericanas. Guayaquil, Ecuador, 1982: 349-357.

ALONSO, A.; GONZÁLES, L. "Introduccion". Introdução ao texto El mundo de los Incas (1571) de Polo de Ondegardo. Cronicas de America, Historia 16, Madri, 1990: 7-25.

ALVA. W. "Una tumba con máscara funerária de la costa norte del Perú." AVA-Beitrage, 1985, 7: 411-421.

ANDRADE C., "Breve Comentario de la Feria de Incahuasi". Sarasara, 1944, n. 24-26: 49-51.

APPADURAI, A. The Social Life of Things. Commodities in Cultural Perspective. Cambridge University Press, 1988.

ARGUEDAS, J. M. "Prologo". Introdução ao texto Dioses y hombres de Huarochiri de Francisco de Ávila. Instituto de Estudios Peruanos, Lima, 1966.

ASSADOURIAN, C. S. El sistema de la economia colonial. Mercado interno, regiones y espacio económico, Lima, 1982.

ASSADOURIAN, C. S. "Las rentas reales, el buen gobierno y la hacienda de Dios: el parecer de 1568 de fray Francisco de Morales sobre la reformación de las Indias". Histórica, Lima, 1985, vol. IX, n 1: 75-130.

BATE, L. F. "Notas sobre el materialismo historico en el proceso de investigacion arqueológica". Boletin de Antropologia, 1989, 19: 5-29. 
BAUDIN, L. Les Incas du Pérou. Paris, 1942.

BAUDIN, L. El Imperio Socialista de los Incas. Santiago, Ed. Zig-Zag, 1943.

BAUDIN, L. La vida cotidiana en el tiempo de los Incas. Buenos Aires, Nueva Colección Clio, 1955.

BAUER, B. S. The development of the Inca State. University of Texas Press, Austin, 1992.

BAUGHT, T. G.; ERICSON, J. E "Trade and Exchange in a Historical Perspective". The American Southwest and Mesoamerica: Systems of Prehistoric Exchange. Baugh and Ericson (eds.), Plenun Press, N. Y., 1992.

BEALS, R.L.; HOIJER, H. Introdución a la Antropología. Universidad de California, Los Angeles, Aguilar, 1968.

BENNETT, W. C. "Excavations in Bolivia" Anthropological Papers, American Museum of Natural History, New York, 1936, vol. 35.

BERNAD, C.; GRUZINSKI, S. História do Novo Mundo. Da descoberta à conquista, uma experiência européia (1492-1550). Editora da Universidade de São Paulo, São Paulo, 1997.

BERnAD, C.; GRUZINSKI, S. Histoire du Noveau Monde. Les Métissages. Paris, Fayard, 1993

BLAU, P. M. Exchange and Power in Social Life. N. Y., Wiley, 1964.

BLAU, P. M. "Intercambio Social". DAVID, L. (org.), Enciclopedia Internacional de las Ciencias Sociales. Madri, Aguilar, 1974, vol. 6: 185-190.

BOHANNAN, P. "The impact of money on an African Subsistence Economy" DALTON, G. (ed.) Tribal and Peasant Economies. New York, The Natural History Press, 1967: 123-135.

BORAH, W. Early Colonial Trade and Navigation Between Mexico and Peru. Iberoamericana. Berkeley: University of California Press, 1954, vol. 38. 
BRAVO, M. C. "La economia andina del siglo XVI: continuidad y cambio en los mecanismos de producción y distribuición" Revista de la Universidad Complutense. Madri, 1901, n 117: 290-316.

BROMLEY, R. J. "El Intercambio de Productos Agrícolas entre la Sierra y la Costa Ecuatoriana". Revista Geográfica, 1974, n.78.

BRUHNS, K. O . Ancient South American, Cambridge University Press, 1994.

BRUMFIEL, E. M.; EARLE, T. K. Specialization, exchange, and complex societies. Cambridge University Press, Cambridge, 1990.

BURCHARD, R. E. "Coca y trueque de alimentos". ALBERTI, G.; MAYER, E. (orgs.) Reciprocidad y Intercambio en los Andes peruanos. Instituto de Estudios Peruanos, Lima, 1974.

BURCHARD, R. E. "The Role of Coca in andean Peasant Communities". XXXIX Congreso Internacional de Americanistas. Lima, 1970.

BURZIO, H. F. "La primera moneda acuñada en Lima com el signo P (Peru) en vez de L (Lima), al fundarse su Casa de Moneda en 1565". Boletin Ibero Americano de Numismática.

BURZIO, H. F. Diccionario de la moneda hispano-americana. Santiago de Chile, 1956.

BURZIO, H. La Ceca de la villa imperial de Potosi y la moneda colonial. Buenos Aires, 1945.

BURZIO, H. La Ceca de Lima (1565-1824), Madri, 1958.

BUTTER, L.J.C., BARREDA, E.M. "Peruviam Archaeology: Crisis or Development?". Society of American Archaeology, 1995, vol. 13, n 3: 18-20.

CARDENAS M., M. "Presencia de Concha y Hueso en el Antiguo Perú". Boletín del Seminário de Arqueología. PUC, Lima, Abril, 1969, n.2: 1-61.

CARDOSO, C. F. S. América Pré-colombiana. São Paulo, Brasiliense, 1981. 
CARLUCI, M. A. "Recientes investigacines arqueológicas en la Isla de La Plata (Ecuador)". Humanitas. Quito, 1966, n 1: 33-65.

CARO, D. A. "Pastoral Marketing in the Andes". Museo de Etnografía y Folklore de La Paz, 1977, n.473.

CHAPMAN, C. "Ports of Trade Enclaves in Aztec and Maya Civilizations" POLANYI, K. Trade and Market in Early Empires. Economies in History and Theory. N. York, The Free Press, 1957: 114-153.

CHAYANOV, A. V. On the theory of peasant economy. R. D. Irwin, Homewood, 1966.

CIPOLLETI, M. S. "Llamas y Mulas, Trueque y Venta. El Testimonio de un arriero puneño". Revista Andina. Cusco. Año 2, 1984, n. 2: 513-538.

COCK, G. A. "Poder, Riqueza de un Hatun Curaca del Valle del Jequetepeque en el Siglo XVI". Historia y Cultura, Lima, 1984, 17: 55-193

COHN, G. Max Weber. São Paulo, Ática, 1991.

CONKLIN, W. J. "The information system of Middle Horizon quipus". Annals of the New York Academy of Sciences. 1982, 385: 261-281.

CONRAD, G. W.; DEMAREST, A. (eds.) Ideology and pre-columbian civilizations . New Mexico: School Am. Res. Press, Santa Fe, 1992.

CONRAD, G. W.; DEMAREST, A. (eds), Religion and Empire. The dynamics of Aztec and Inca expansionism. Cambridge, England: Cambridge University Press, 1984.

CORDY-COLLINA, A. "Spondylus and the Ecuatorian Connection". Comunicação apresentada em Dumbarton Oaks Symposium. The Northern Dynasties: Kingship and StateCraft in Chimor. Washington D. F., 1985.

COSTIN, C. L.; EARLE, T. "Status distinction in a legitimation of power as reflected changing patterns of consumption in Late Pre-hispanic Peru". American Antiquity, 1989, 54: 691-714. 
COVEY, R. A. "Inka administration of the far South Coast". Latin America Antiquity. 2000, 11(2): 119-138.

CRAIG JR., F. "Coinage of the Viceroyalty of el Perú: an overview". Bischoff, W. The coinage of el Perú (ed.), New York, 1989.

CRIADO, F. "The visibility of archaeological record and the interpretation of social reality". HODDER, I. and alli (eds.) Interpreting Archaeology. Finding meaning in the past. Routledge, 1995: 194-209.

DALTON, G. "Primitive Money". Tribal and Peasant Economies. N. York, Natural History Press, 1967: 254-281.

D'Altroy, T. Provincial power in the Inka empire. Smithsonian Intitution Press, Washington, D. C., 1992.

D'ALTROY, T.; EARLE, T. "Staple finance, wealth finance, and storage in the Inka political economy". Current Anthropology, 1985, 26 (2): 187-206.

DARGENT CHAMOT, E. "Las Curiosas Hachitas-moneda". El Comercio. Lima, 13 de Enero de 1985: E-8.

DARGENT-CHAMOT, E. "Condicionamentos geográficos para el estabelecimento de las Cecas peruanas el siglo XVI". Caceta Numismatica, Barcelona, 1988, n90, III.

DARGENT-CHAMOT, E. "The Early Lima Mint (1568-1572)". Bischoff, W. (ed.) The Coinage of el Perú, New York, 1989.

DAVINDSON, J. R. "El Spondylus en la Cosmología Chimú". Revista del Museo Nacional. Lima. 1981, Tomo XLV: 75-88.

DÉMONIO, L. "A problemática anglo-saxônica: economia política e antropologia". POUILlON, F. (org.) A antropologia econômica. Correntes e problemas. Edições 70, Lisboa, 1976: 9-57.

DEW, E. Politics in the Altiplano. The Dynamicas of Change in rural Peru. University of Texas Press, 1969. 
DILLEHAY, T. "Tawantinsuyu integration of the Chillon Valley, Peru: a case of Inca GeoPolitical Mastery". Journal of Field Archaeology, 1988, 4: 397-405.

DOLLFUS, O "The tropical Andes: a changing mosaic". MURRA, J.; REVEL, J.; WACHTEL, N. Anthropological history of andean polities. Cambridge University Press, 1986: 11-22.

DORSEY, G. "Archaeological investigations on the island of La Plata, Ecuador". Anthropology Series Museum of Natural History, Publication 56, Chicago, 1901, 2(5).

DOUGLAS, M.; FORDE, D. "Primitive economies." SHAPIRO (ed.) Man, Culture and Society, Oxford, 1956: 330-344.

DUPRÉ, G.; REY, P. P. "Réflexions sur la pertinence d'une théorie de l'histoire des échanges". Cahiers Internationaux de Sociologie, 1969, XLVI: 133-162.

DUVIOLS, P. Cultura Andina y Represíon. Cuzco: Centro de Estudios Rurales Andinos, 1986.

EARLE, T. K. "Commodity exchange and markets in the Inca state: recent archaeological evidence". PLATTNER S. (ed.) Markets and marketing. (S.E.A. Monographs in Economic Anthropology, Univesity Press of America, 1985: 369-397.

EARLE, T. K. How chiefs come to power. The political economy in Prehistory. Stanford, Stanford University Press, 1997.

EARLE, T. K. "Specialization and the production of wealth: Hawaiian chiefdoms and the Inka empire." BRUMFIEL, E. M. \& EARLE, T. K. Specialization, exchange, and complex societies. Cambridge University Press, Cambridge, 1990: 64-75.

EARLE, T. K. "Wealth Finance in the Inka Empire: evidence from the Calchaqui Valley, Argentina". American Antiquity, 1995, vol. 59, n³: 443-460.

EARLE, T. K.; D'ALTROY, T. N. "The political economy of the Inka empire: the archaeology of power and finance". LAMBERG-KARLOVSKY (ED.) Archaeological thought in America. 
EINZIG, P. Primitive Money. Glasgow, Blakie and Son, 1966.

ELERA AREVALO, C. "Hallan Monedas prehispánicas en Lambayeque". El Comercio. Lima, 28 de mayo de 1984.

ELLIOT, J. H. "A conquista espanhola e a colonização da América". BETHELL, L. (org.) América Latina colonial. São Paulo, EDUSP. 1998, vol. 1: 135-194.

ELLIOT, J. H. "A Espanha e a América nos séculos XVI e XVII". BETHELL, L. (org.) América Latina colonial. São Paulo, EDUSP. 1998, vol. 1: 283-337.

EQUIPO CCAIJO, A. "Economia Campesina y Espacios de Control desde el Estudio de las Ferias de una Región". Allpanchis. Cusco, 1984, n. 23: 105-122.

ESPINOZA SORIANO, W. "La Moneda Andina". Numismática. Lima. 1981, Tomo XXXII:10-17.

ESPINOZA SORIANO, W. Los Incas, Economia, Sociedad y Estado en la Era del Tahuantinsuyo. La Victoria, Peru: Amaru editores, 1997

ESPINOZA SORIANO, W. (org.) Los modos de produccion en el imperio de los Incas. Amaru Editores, Lima, 1989.

ESPINOZA SORIANO, W. La Destrucción del Imperio de los Incas. Lima: Amaru editores, 1990.

ESPINOZA SORIANO, W. Artesanos, transacciones, monedas y formas de pago en el mundo andino. Siglos XV y XVI. Banco Central de Reserva del Peru. Lima, Peru, 1987. Tomo I e II.

ESTEVA F., C. "Un Mercado en Chinchero, Cusco". Anuario Indigenista. México. 1970, XXX: 213-254.

ESTRADA, E. Arqueología de Manabí Central. Publicaciones del Museo Víctor Emilio Estrada. Guayaquil, 1962, n.7.

FAVRE, H. Os Incas. Coleção Saber Atual, São Paulo, Difel, 1974. 
FINLEY, M. I. "Arqueologia e História". Uso e Abuso da História. São Paulo, Martins Fontes, 1989.

FIRTH, R. "Magnitudes and values in Kula exchange." LEACH, J.; LEACH, E. The Kula. Cambridge University Press, Cambridge, 1983: 89-102.

FIRTH, R. Themes in economic anthropology. Tavistock Publications, London, 1967.

FONSECA MARTEL, C. "La Economia Vertical y la Economia de Mercado en las Comunidades Altinas del Perú". Vide Iñigo Ortiz de Zuñiga: Visita de la Província de León de Huánaco en 1562. Lima. 1972, Tomo II: 315-338.

GÁNDARA, M. "La vieja 'nueva arqueologia'. Primera parte y segunda parte". Reimpresiones de Antropologia Americana, IPGH, México, 1982: 59-159.

GIUCCI, G. Viajantes do Maravilhoso. O Novo Mundo. São Paulo, Companhia das Letras, 1992.

GLAVE, MIGUEL "La producción de los trajines: coca y mercado interno colonial". HISLA, Lima, 1985, n VI: 21-42.

GODELIER, M. Economia, fetichismo y religion en las sociedades primitivas. Madri, Siglo Veinteuno, 1985.

GODELIER, M. "El concepto de formacion economica y social: el ejemplo de los Incas". ESPINOZA SORIANO, W. (org.) Los modos de produccion en el imperio de los Incas. Amaru Editores, Lima, 1989: 265-283.

GOLDSTEIN, P. S. "Exotic goods and everyday chiefs: long-distance exchange and indigenous sociopolitical development in the South Central Andes". Latin American Antiquity, 2000, 11 (4): 335-361.

GOLTE, J. "Algunas Consideraciones acerca de la Producción y Distribución de la Coca en el Estado Inca". XXXVIII Congreso Internacional de Americanistas. Stuttgart, 1970: 78-471.

GREENBLATT, S. Possessões maravilhosas. Editora da Universadade de São Paulo, São Paulo, 1996. 
GRIERSON, P. "The origins of money." Research in Economic Anthropology. 1978, 8: $1-35$.

GROLliG, F. X. "Indians Markets in the Altiplano of Perú". XXXVI Congresso Internacional de Americanistas. Sevilla. 1964, Vol. 3: 403-406.

GUILLÉN GUILLÉN, E. Versión Inca da la Conquista. Lima: editorial Milla Batres, 1974.

HARRIS, O., LARSON, B.; TANDETER, E. La Participación Indígena en los Mercados Surandinos, siglos XVI-XX. La Paz: Centro de Estudios de la Realidad Económica y Social, 1987.

HARTMANN, R. "Comercio y Economía durante la Ocupación Incaica". Historia del Ecuador. Salvat Editores, Navarra, España 1981, vol. 2: 161-164.

HARTMANN, R. "Mercados y Ferias Prehispánicos en el Área Andina". Boletín de la Academia Nacional de Historia, 1971, 54, n. 118: 35-214.

HERCKSCHER, E. La Época Mercantilista. México, Fondo De Cultura Económica, 1983.

HOCQUENGHEM, A. M. "Rutas de entrada del mullu en el extremo norte del Perú". Bulletin du l'Institut Français du Études Andines, 1993, 22(3), 701-719.

HODDER, I. "Archaeology in 1984". Antiquity, 1984, 43: 25-32.

HODGES, R. Primitive and peasant markets. Blackwell, Cambridge, 1988.

HOLM, O . Monedas primitivas del Equador prehistórico. La pieza del mes. 3. Exposición presentada por la Sección Antropología Cultural. Núcleo del Guayas de la Casa de la Cultura Equatoriana. Guayaquil, 1975.

HOLM, O . "Hachas monedas del Equador". Cultura, 1978, vol. 1, nº1: 11-25.

HOLM, O. "Hachas Monedas del Ecuador". III Congresso Peruano. El Hombre y la Cultura Andina, Actas y Trabajos. Universidad Nacional Mayor de San Marcos, Lima, 1978, tomo I: 347-361. 
HOLM, O. Monedas primitivas del Equador. Discurso de incorporación como miembro de número del Centro de Investigaciones de Guayaquil, 1966.

HOSLER, D.; HESTHER, L.; HOLM, O. Axe-Monies and their Relatives. Washington D. C., Dumbarton Oaks, 1990.

HUMPHREY, C.; HUGH-JONES, S. (eds.) Barter, Exchange and Value. An anthropological approach Cambridge University Press, 1992.

JACOME, N. "La Tributación Indígena en el Ecuador". Bulletin de l'Institut Français d'Études Andines, 1974, 3, n.1: 449-80.

JULIEN, C. "How Inca decimal organization worked." Ethnohistory, 1988, 35: 257-279.

JULIEN, C. "Finding a fit: archaeology and ethnohistory of the Incas". MALPASS, M. (ed.) Provincial Inca. University of Iowa Press, iowa city, 1993: 177-233.

LALONE, D. "The Inka as a nonmarket economy: supply on command versus and demand". ERICSON, J.; EARLE, T. Contexts for prehistoric exchange. New York, Academic Press, 1982: 291-316.

LANDÁZURI, C. Los curacazgos pastos prehispanicos: agricultura y comércio, siglo XVI. Ediciones Banco Central del Ecuador, Quito, 1995.

LANNING, E. P. Peru before the Incas. Prentice-Hall. Inc., Englewood Cliffs, New Jersey, 1967.

LAVALlÉE, D. "Contacts et échanges dans les Andes". Le Grand Atlas de L’Archéologie. Encycloaedia Universalis, 1985.

LEATHERMAN, T. L., CAREY, J. W.; THOMAS R. B. "Socioeconomic Change and Patterns of Growth in the Andes". American Journal of Physical Anthropology. 1995, vol. 97, n. 3: 307-322.

LEFORT, C. "A troca e a luta dos Homens". LEFORT, C. et all. O Método Estruturalista. Rio de Janeiro, Zahar, 1967: 64-79. 
LEHMANN, D. Ecology and Exchange in the Andes. Cambridge, Cambridge University Press, 1982.

LEÓn PORTILHA, M. A conquista da América vista pelos índios. Relatos Astecas, Incas e Maias. Petrópolis, Vozes, 1984.

LEVELLIER, R. Don Francisco de Toledo supremo organizador del Peru. Su vida, su obra (1515-1582), anos de andanzas y de guerras. Editora Espasa-Calpe, Madri, 1935.

LE VINE, T. Y. "Inka labor service at the regional level: the functional reality". Ethnohistory, 1987, 34 (I): 14-46.

LEVI-STRAUSS, C. "The Principle of Reciprocity". Lewis A. Coser \& Bernard Rosenberg (eds.), Sociological Theory. N. Y., Macmillan, 1969: 84-94.

LUMBrerAS, L. G. La Arqueología como Ciencia Social. Promoción Ed. Inca, Lima, 1981.

LUMBrerAS, L. G. Arqueología de la América Andina. Editorial Milla Batres. Lima, 1981.

LUMBRERAS, L. G. Pueblos, las culturas y artes del antiguo Perú, Lima, 1969.

LUMBRERAS, L. G. "Organización y economia Inka". ESPINOZA SORIANO, W. (org.) Los modos de produccion en el imperio de los Incas. Amaru Editores, Lima, 1989: 89-93.

MALINOWSKI, B. "Principales características del Kula". Los Argonautas del Pacífico Occidental. Barcelona, Ed. 62, 1975: 95-116.

MANN, M. Sources of social power. Cambridge University Press, Cambridge, 1986.

MARCOS, J. G "Intercambio a Larga Distancia en América. El Caso del Spondylus". Boletín de Antropología Americana. México, 1980, n.1: 124-128.

MARCOS, J. G.; NORTON, P. "Interpretación sobre la Arqueología de la Isla de La Plata". Miscelánea Antropológica Ecuatoriana. Quito, 1981, n.1: 136-154. 
MARKY, D. C. "Objetos de Concha". Boletin del Seminário de Arqueologia. Lima, 1970, $\mathrm{n}^{\circ}$ 6: 36-37.

MARQUES, M. G. Introdução à Numismática. Lisboa, Dom Quixote,1984: 9-31.

MARTEL, C. F. Sistemas Económicos Andinos. Biblioteca Andina. Lima.

MARTEL, C. F. "El modelo andino de la complementaridad ecológica". Revista del Museu Nacional, Lima, 1983-85, Tomo XLVII: 291.

MARX, K. O capital. Civilização Brasileira, Rio de Janeiro, 1968, Livro 1, vol. 1.

MASON, J.A. Antiguas Culturas del Peru. Mexico, Fondo de Cultura.

MASUCCI, M.A. "Marine shell bead and the role of domestic craft activities en the economy of the Guangala phase, southwest Equador". Latin American Antiquity. 1995, vol. 6, n 1: 70-84.

MASUDA, SHOZO. "Nueva técnica de investigación etnográfica andina: informaciones acerca de la coca referidas en las crónicas". Contribuiciones a los Estudios de los Andes Centrales. Universidad de Tokio, 1984: 1-58.

MATIENZO, J. de Gobierno del Perú (1567), Paris-Lima, 1967.

MAUSS, M. "Ensaio sobre a dádiva. Forma e razão da troca nas sociedades arcaicas." Sociologia e Antropologia, EDUSP, São Paulo, 1974.

MAYER, E. "Un Carnero por un saco de papas: aspectos del trueque en la zona de Chaupiwaranga, Pasco". XXXIX Congresso Internacional de Americanistas. Lima, 1970, vol. 3.

MEDINA, J. T. "Monedas Usadas por los Indios de América al Tiempo del Descubrimiento, según los Antiguos Documentos y Cronistas Espanholes". Actas del XVII Congresso Internacional de Americanistas. Buenos Aires, 1912: 556-567.

MEILLASSOUX, C. "Essai d'interprétation du phénomène économique dans les sociétés traditionelles d'auto subsistance". Cahiers d'Etudes Africaines. 1960, I (4): 38-67. 
MELLAFE, R. Evoluzione del salario nel viceregno del Perú. Napoli, 1966.

MENESES, U.T.B. "A cultura material no estudo das sociedades antigas". Revista de História, 1983, n¹15: 103-117.

MENZEL, D. "The Inca occupation of the South Coast of Peru". South Western Journal of Anthropology. 1959: 125-142.

MERKEL, J. F.; VELARDE, M. I. "Naipes. Pre-hispanic axe money currency of Peru". Minerva. The international Review of ancient art \& archaeology, Britain, 2000, vol. 11, n. 1: 52-55.

MEUNIER, R. "Formas de circulação". POUILLON, F. (org.) A antropologia econômica. Correntes e problemas. Edições 70, Lisboa, 1976: 203-252.

MONIOT, H. "Em França: uma antropologia de inspiração marxista". POUILLON, F. (org.) A antropologia econômica. Correntes e problemas. Edições 70, Lisboa, 1976: 59-100.

MOORIS, C. "From principles of ecological complementarity to the organization and administration of Tawantinsuyu". MASUDA, S., SHIMADA, I.; MORRIS, C. (eds.) Andean Ecology and Civilization. University of Tokio Press, Tokio, 1985: 477-490.

MORRIS, C. "Inka strategies of incorporation and governance". FEINMAN, G.; MARCUS, J. Archaic States. School of American Research Press, Santa Fé, 1998: 293-309.

MORRIS, C. "Storage, supply and redistribution in the economy of the Inka state". MURRA, J.; REVEL, J.; WACHTEL, N. Anthropological history of andean polities. Cambridge University Press, 1986: 59-68.

MOSELEY, M. E. "Prehistoric principles of labor organizationin the Moche Valley, Peru". American Antiquity, 1975, vol. 40, n²: 191-196.

MOSELEY, M. E. Power and property in Inca Peru. Columbia Press University, N. Y., 1958. 
MOSELEY, M. E. "Structure and history in the dynastic: Lord of Chimor". MOSELEY, M.; CORDY-COLLINS, A. Norther dynasties: kingship and statecraft in Chimor. Dumbarton Oaks, Washington, DC, 1990.

MURRA, J. "Una apreciacion etnologica de la visita ". Visita hecha a la provincia de Chucuito por Garci Diez de San Miguel en el año de 1567. Lima, Ediciones de la Casa de la Cultura del Perú, 1964.

MURRA, J. "Temas de estructura social y economica en la etnohistoria y el antiguo folklore andino". Folklore Americano, Lima, 1962, año X, n. 10: 226-238.

MURRA, J. Formaciones Económicas y Políticas del Mundo Andino. Lima, Instituto de Estudios Peruanos, 1975.

MURRA, J. "Consideraciones historicas acerca del cultivo de la hoja de coca a inicios de la colonia." Revista del Museo e Instituto de Arqueologia. Universidad Nacional de San Antonio Abad, 1991, n. 24: 105-121.

MURRA, J. La organizacion Economica del Estado Inca. México, Siglo Veintuino, América Nuestra, 1978.

MURRA, J. "La mit'a al Tawuantinsuyu: prestaciones de los grupos étnicos". Revista Chungará. Universidad de Tarapacá, Arica, Chile, 1983, n. 10: 77-94.

MURRA, J. "As sociedades andinas anteriores a 1532". BETHELL, L. (org.) América Latina colonial. São Paulo, EDUSP. 1998, vol. 1: 63-99.

MURRA, J. "The expansion of the Inka state: armies, war and rebellions". MURRA, J.; REVEL, J.; WACHTEL, N. Anthropological history of andean polities. Cambridge University Press, 1986: 49-58.

MURRA, J. V. "La función del tejido en varios contextos sociales en el Estado Inca". Actas y Trabajos del Segundo Congreso Nacional de Historia del Perú. Lima, 1958: 40-215.

MURRA, J. Visitas de los cocales en los yunka de La Paz. Instituto de Estudios Fiscales del Ministerio de Hacienda. Madri, 1988. 
NEVES, W. A. "A Primeira Descoberta da América". Ciência Hoje, vol. 15, no 86: 38-89.

NETHERLY, P. Local level Lords on the north coast of Peru. Ph.D. Dissertation, Department of Anthropology, Cornell University, 1978.

NEWMAN, E. P.; DOTY, R. G. (eds.) Studies on money in early America. The American Numismatic Society, N. Y., 1976.

NOEJOVICH, H. O. "El Régimen de Bienes en la America Precolombina y el hecho Colonial". VII Simpósio Internacional de História Económica, Lima, Junio de 1986.

NORTON, P. "Excavaciones en la Isla Sagrada de La Plata". Ecuador a la Sombra de los Volcanes. Venezia. 1981: 34-36.

O’NEALE, L M. "Pequeñas Prendas Cerimoniales de Paracas". Revista del Museo Nacional. Lima, 1935, tomo IV: 66-245.

OCHOA, J. A. F. "Pastoreo, tejido e intercambio". Pastores de Puna. Uywamichip Punarunakuna. Instituto de Estudios Peruanos. Lima, 1977: 133-154

O'GORMAN, E. A invenção da América, México, Fondo de Cultura Econômica, 1978.

O'GORMAN, E. "Prologo y Introdução". Introdução ao texto História Natural y Moral de las Índias de José de Acosta. México, Fondo de Cultura Económica, 1979.

OLAYA, B. "Hachas monedas en el caserio de cristales, Tumbes". Revista del Museo de Arqueologia. Universidad Nacional de Trujillo, 1993, 4: 105-113.

OLIVEIRA, R. C. (org.) Marcel Mauss. São Paulo, Ática, 1979.

PARKERSON, P. T. "The Inca Coca Monopoly: Fact or Legal Fiction?". Proceedings of the American Philosophical Society. 1983, n.1. 127: 23-107.

PARRY, J.; BLOCH, M. (eds.) Money and the morality of exchange. Cambridge University Press, 1989. 
PATTERSON, T. C. "Ideology, class formation and resistence in the Inca State". Crit. Anthrpol. 1986, 6: 75-85.

PATTERSON, T. C. The inca empire, the formation and desintegration of a precapitalist State. Oxford, England, 1991.

PAULSEN, A. C. "The thorny oyster and the voice of god: Spondylus and Strombus in Andean Pre-history". American Antiquity, 1974, vol. 39, n 4.

PAULSEN, A. C. "Patterns of maritime trade between south coastal Ecuador and western Mesoamerica, 1500 B.C.-A.D. 600." BENSON, E. (ed.) The sea in the pre-columbian world. Dumbarton Oaks, Washington D.C., 1977: 141-160.

PEASE, F. G. Y. Las Crónicas y los Andes. Fondo de Cultura Económica, Lima, 1995.

PEASE, F. G. Y. "Version paleográfica y prólogo de Nueva Coronica y Buen Gobierno." Casa de Cultura del Peru, Lima, 1969: 9-22.

PEASE, F. "The formation of Tawantnsuyu: mechanismis of colonization and relationship with ethnics groups". COLLIER, G. A., ROSALDO R. I.; WIRTH, J. D. The Inca and Aztec states 1400-1800: anthropology and history. Academic Press, New York, 1982: 173-198.

PEDERSEN, ASBJORN "El ajuar funerario de la tumba de la huaca Menor de Batán Grande (Lambayeque, Peru)". Actas del XLI Congreso Internacional de Americanistas. México, 1976, vol. II: 60-73.

PILLSBURY, J. "The thorny oyster and the origins of empire: implications of recently uncovered Spondylus imagery from Chan Chan, Peru". Latin American Antiquity, 1996, 7 (4): 313-340.

POLANYI, K. "Marketless trading in Hammurabi's Time". POLANYI, K. Trade and Market in Early Empires. Economies in History and Theory. New York, The Free Press, 1957: 12-26.

POLANYI, K. "The Economy as Instituted Process". POLANYI, K. Trade and Market Empires. Economies in History and Theory. N. York, The Free Press, 1957: 243270. 
POOLE, D. Los "Santuários Religiosos en la Economía Regional Andina". Allpanchis. Cusco. 1982, n.19: 79-116.

PORRAS BARRENECHEA, R. Los Cronistas del Perú (1528-1650). Lima: Banco de Crédito del Perú, 1986.

POUILLON, F. "A determinação de um modo de produção: as forças produtivas e sua apropriação". POUILLON, F. (org.) A antropologia econômica. Correntes e problemas. Edições 70, Lisboa, 1976: 101-149.

PRESSCOTT, W. H. History of the conquest of Peru. With a preliminary view of the civilization of the Incas. London, G. Allen \& Unwin, 1959 (1886).

QUIGGIN, A. H. A survey of primitive money. The leginning of currency. London, Methuen \& Co.,. New York, Barnes \& Noble, 1949.

RAMÍREZ, S. E. "The Inca conquest of the North Coast: a historian's view". MOSELEY, M.; CORDY-COLLINS, A. The Northern dynasties: kingship and statecraft in Chimor. Dumbarton Oaks, Washington, D. C. 1990: 507-537.

RAMÍREZ, S. E. "La Organización Económica de la Costa Norte: un Análisis preliminar del período prehispánico tardío". CASTELLE, A. et all. Etnohistoria y Antropología Andina, Lima: Centro de Preyeccíon Cristiana, 1981: 97-281.

RAMÍREZ, S. E. The World Upside Down. Cross-Cultural Contact and Conflict in Sixteenth-Century Peru. California, Stanford University Press, 1996.

RAMIREZ-HORTON, S. "Retainers of the Lords or Merchants: a case of mistaken identify?". Senri Ethnological Sudies, 1982, 10.

RENFREW, C.; BAHN, P. "Que contatos Tenían? Comercio e Intercambio". RENFREW, C. \& BAHN, P. Arqueologia: teorias, metodos y práticas. Torrrejón de Ardoz, Madrid, 1993: 321-353.

REVERE, R. B. "No man's Coast: Ports of Trade in the Eastern Mediterranean". POLANYI, K. Trade and Market in Early Empires. Economies in History and Theory. N. York, The Free Press, 1957: 38-63. 
ROSTWOROWSKI, M. Conflicts over coca fields in XVI ${ }^{\text {th }}$ century, Perú. Memoirs in Latin American Etnohistory \& Archaeology. University of Michigan, 1988, n. 21.

ROSTWOROWSKI, M. Historia del Tahuantinsuyu. Instituto de Estudios Peruanos, Lima, 1998.

ROSTWOROWSKI, M. "Pesos y medidas en el Perú pre-hispánico". Actas y trabajos del II Congreso Nacional de Historia del Perú. Epoca pre-hispanica. Lima, 1958, vol. II: $107-119$.

ROSTWOROWSKI, M. "Mercaderes del Valle de Chincha en la Época Prehispánica: un Documento y unos Comentarios". Revista Española de Antropología Americana. Madri, 1970, tomo V: 7-61.

ROSTWOROWSKI, M. "Pescadores, artesanos y mercaderes costeños en el Peru prehispanico". Revista del Museo Nacional. 1975, XLI: 311-349.

ROSTWOROWSKI, M. "Plantaciones prehispánicas de coca en la vertiente del Pacífico". Revista del Museo Nacional. Lima, 1973, Tomo XXXIX: 193-224.

ROWE, J. H. "Inca culture at the time of the spanish conquest". STEWARD, J, (org.) Handbook of South american Indians. Smithsonian Institution, Washington D. C., 1946, vol. 2: 183-330.

SAHLINS, M. Stone age economics. Bristol, Tavistock Publications, 1970.

SAHLINS, M. Sociedades tribais. Rio de Janeiro, Zahar, 1970.

SALOMON, F. "A north andean status trader complex under Inka rule". Ethnohistory, 1987, 34 (I): 63-77.

SALOMON, F. Native Lords of Quito in the age of Inkas. Cambridge, Cambridge University Press, 1986.

SANTIAGO, T. (org.) América Colonial, Rio de Janeiro, Pallas, 1975. 
SCATAMACCHIA, M. C. M. "Etno-historia e interpretação: documentação textual para o estudo dos grupos Tupi e Guarani". Revista de Arqueologia Americana, 1996, n¹1, julho-dezembro:79-102

SELLSCHOPP, E. Las acuñaciones de la Ceca de Lima. Lima, 1964, 2 vols.sentido Actual. Mexico, Fondo de Cultura Económica, 1992.

SHADY SOLIS, R. "El Comercio en el Perú Prehispánico". Boletin de Lima. 1985, n.38: 35-39.

SHAEDEL, R. P. "Andean World View: Hierarch or Reciprocity, Regulation or Control?". Current Antropology, 1988, 29, n. 5: 75-768.

SHAEDEL, R. P. "Murra: formaciones económicas y politicas del mundo andino". American Antiquity. 1977, vol. 42, n 1: 129-131.

SHAEDEL, R. P. "El comercio en el antiguo Peru". SUÁREZ, M. (cord.) Historia, antropología y política. Homenaje a Angel Palerm I. Universidad Iberoamericana, Alianza Editorial Mexicana, México D. F., 1990: 330-372.

SHIFFER, M. B. Formation Process of the archaeological record, University of Utah Press, 1996, Part II, Cap. 3:25-43.

SHIMADA, I. "Economy of a prehistoric urban context: commodity and labor flow at Moche V Pampa Grande, Peru". American Antiquity, 1978, vol.43, n 4: 569- 592.

SHIMADA, I. "La Cultura Sican. Caracterización Arqueologica". Presencia Historica de Lambayeque. Ediciones Representaciones, 1985.

SHNAPP, A. "El Comercio Prehispánico en la Costa Ecuatorial del Pacífico". XLV Congreso Internacional de Americanistas. Bogotá, Julio de 1985.

SHNAPP, A. "A Arqueologia". História: Novas Abordagens. Rio de Janeiro, Francisco Alves, 1976

SINOPOLI, C. M. "The archaeology of empires". Annual Review of Anthropology, 1994, 23: $159-180$. 
SPALDING, K. "Resistencia y Adaptación: el Gobierno Colonial y las Élites Nativas". Allpanchis 15, n. 17, 18, 1981: 5-21.

STANISH, C. "Nonmarket imperialism in the prehispanic Americas: the Inka occupation of the Titicaca Basin". Latin American Antiquity, 19978 (3): 195-216.

STANISH, C. "Household archaeology: testing models of zonal complementarity in the South Central Andes". American Anthropologist, 1989, 91: 7-24.

STANISH, C. Ancient andean political economy. University of Texas Press, Austin, 1992.

STANISH, C. et all. Archaeological research in the Juli-Desaguadero region of the lake Titicaca Basin, Southern Peru. Manuscript on file, Field Museum of Natural History, Chicago, 1994.

STEFANELLI. E. C. Select Numismatic Bibliography, N. Y., 1965

STEWARD, J. H. (ed.) Handbook of South America Indians. N. Y., Cooper Square Publishers, 1963, vol. 6.

SZASZDI, A. C. "Módulo experimental para la interpretación de las hachas-monedas de la costa ecuatoriana". Cuadernos Prehispánicos. Universidad de Valladolid. Año VIII, 1980, n8: 69-76.

THEODORO, J. Descobrimentos e Colonização. São Paulo, Ática, 1987.

THEODORO, J. América Barroca. Tema e Variações. São Paulo, EDUSP e Nova Fronteira, 1992.

TODOROV. T. A Conquista da América. A questão do outro. São Paulo, Martins Fontes, 1983.

TRIGGER, B.G. "Ethnohistory: problems and prospects". Ethnohistory, 1982, 29 (1): 109.

TRIGGER, B.G. "História e Arqueologia". Além da História: os métodos da préHistória. São Paulo, Edusp, 1973. 
TROSPER, R. L. "Tradicional American Indian Economic Policy". American Indian Culture and Resarch Journal, 1995, vol. 19, n.1: 65-96.

URBANO, H. "La figura y la palabra. Introducción al estudio del espacio simbólico andino". URBANO, H. (org.) Mito y simbolismo en los Andes. La figura y la palabra. Centro de Estudios Regionales Andinos 'Bartolomé de las Casas'. Cuzco, 1993: 7-50.

VALCARCEL, L. E. "Indian markets and fairs in Perú". Handbook of South American Indians. Smithsonian Institution. Washington D.C., 1946,vol. 2: 477-482.

VALENCIA ESPINOZA, A. Pesos y Medidas Inkas. Cuzco: Centro de Estudios Andinos, 1982.

VALENSI, L. "História e Antropologia Econômica: a obra de Karl Polanyi". VALENSI, L. Para uma história antropológica: a noção de reciprocidade. São Paulo, Edições 70, 1974: 15-26.

VÉDOVA, A.( org.) Diskurs 70 - Culturas en la costa del Ecuador. Directorio y Rectorado del colegio Alemán Humboldt de Guayaquil. Guayaquil, 1969-1970

Vignale, P. J. La casa Real de Moneda de Potosi. Buenos Aires, 1944.

WACHTEL, N. Sociedad e ideologia. Ensayos de historia y antropologia andinas. Instituto de Estudios Perunaos, 1973.

WACHTEL, N. "A reciprocidade e o Estado Inca: de Karl Polanyi a John Murra". VALENSI, L. Para uma história antropológica: a noção de reciprocidade. São Paulo, Edições 70, 1974.

WACHTEL, N. "Os índios e a conquista espanhola". BETHELL, L. (org.) América Latina colonial. São Paulo, EDUSP. 1998, vol. 1: 195-239.

WACHTEL, N. Vision des Vaincus: les Indiens du Perou Devant la Conquete Espagnole (1530-1570). França, Gallimard, 1977.

WATSON, P. J. et alli. El método Científico en arqueologia, Alianza Universidad, 1987, Caps. 1 e 3 
WEBER, MAX. Economia y Sociedad. Esbozo de Sociología Comprensiva. México, Fondo de Cultura Económica, 1964.

WEBER, MAX. Historia Económica General. México, Fondo de Cultura Económia, 1964.

WEDIN, AKE. Sistema Decimal en el Imperio Incaico: Estudio sobreestructura politica, division territorial y poblacion Madri, Insula, 1965.

WILLEY, G.; PHILIP, P. Method and Theory in American Archaeology, University of Chicago Press, Caps. I e II: 11-57.

ZUIDEMA, T. "El ayllu peruano". XXXVI Congreso Internacional de Americanistas, Sevilha, 1966: 408-411.

ZUIDEMA, T. "Hierarchy and space in Incaic social organization". Ethnohistory. 1983, 30: 49-75. 